No. 1495

\title{
Immune tolerance by interferon-alpha in experimental arthritis
}

\author{
Jaya Prakash Chalise
}

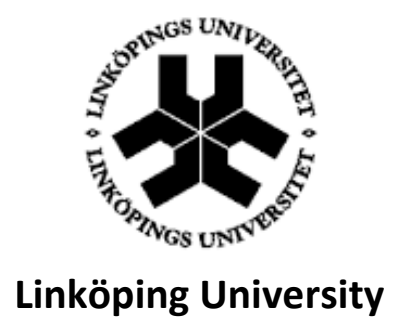

Rheumatology, Autoimmunity and Immune-Regulation (AIR)

Department of Clinical and Experimental Medicine,

Faculty of Health Sciences, Linköping University,

SE-581 85 Linköping, Sweden 
Copyright @ Jaya Prakash Chalise, 2015

ISBN: 978-91-7685-888-2

ISSN: 0345-0082

Cover illustration by Jaya Prakash Chalise and Sudeep Chenna Narendra

Paper I has been reprinted with the permission from John Wiley and Sons Inc.

Paper II is an open access article distributed under the terms of the Creative Commons Attribution License (http://creativecommons.org/licenses/by/2.0), which permits unrestricted use, distribution, and reproduction in any medium, provided the original work is properly cited.

Printed by LiU-tryck, Linköping Sweden, 2015 
'Somewhere, something incredible is waiting to be known' -Carl Sagan 


\section{Supervisor}

Mattias Magnusson, Linköping University, Sweden

\section{Co-supervisor}

Thomas Skogh, Linköping University, Sweden

\section{Faculty opponent}

Richard O Williams, University of Oxford, UK

\section{Funding}

This work was supported by the fundings from Swedish Research Council (Vetenskapsrådet, , Reumatikerförbundet, Magnus Bergvall Foundation, Gustav V 80-years foundation, the Swedish Association against Rheumatism (Reumatikerförbundet) and Linköping University 


\section{ABSTRACT}

Type I Interferons (mainly IFN- $\alpha$ \& IFN- $\beta$ ) belong to a family of cytokines that possess strong antiviral and immunomodulatory properties. Pro- and/or anti-inflammatory effects of type I IFN have been observed in infectious diseases and several autoimmune diseases including SLE, MS, RA and experimental models thereof, but what defines either outcome is largely obscure. The main aim of this thesis is to understand how IFN- $\alpha$ may act anti-inflammatory in a model of antigen-induced arthritis (AIA). In this model, mice are sensitized with methylated-BSA (mBSA) emulsified in Freund's adjuvant at day 1 and 7 followed by intraarticular injection of mBSA in the knee joint at day 21, which induces arthritis within 1 week.

Administration of IFN- $\alpha$ at the time of mBSA sensitizations (day 1 and day 7) but not at induction of arthritis (day 21) clearly protected against arthritis in a type I IFN receptor dependent manner. Humoral immunity might not be involved in this protection as the levels of antigen-specific IgG (total, IgG1, IgG2a and IgG2b), IgA, IgE in serum were not altered in IFN- $\alpha$ treated mice. However, IFN- $\alpha$-protection was accompanied by delayed and decreased antigen-specific proliferative responses in spleen and lymph node cells ex vivo, including impaired proliferative recall responses after intra-articular antigenic challenge.

In the course of AIA, IFN- $\alpha$ inhibited the increase of circulatory IL-6, IL-10, IL-12, and TNF in the sensitization phase (day 0-21) and also the re-call response of IL-1 $\beta$, IL-10, IL-12, TNF, IFN- $\gamma$, and IL-17 induced by intra-articular mBSA challenge in arthritis phase (day 21-28). This IFN- $\alpha$-inhibition of cytokines was also apparent in mBSA-re-stimulated spleen and lymph node cell cultures ex vivo, including inhibited cytokine production in $\mathrm{CD}^{+} \mathrm{T}$ helper cells and macrophages. In contrast to the inhibition of pro-inflammatory cytokines, the levels of immunomodulatory TGF- $\beta$ was clearly enhanced in IFN- $\alpha$-treated mice, both in serum and in re-stimulated leucocytes cultures including both macrophages, especially in the sensitization phase, and in $\mathrm{CD}^{+} \mathrm{T}$ cells in the arthritis phase. By inhibiting TGF- $\beta$ signalling in vivo, the protective effect of IFN- $\alpha$ was shown to be dependent on TGF- $\beta$ signalling in the sensitization phase.

The cytokine TGF- $\beta$ is an activator of the indoleamine 2,3 dioxygnese (IDO1), a potent immune-regulatory component that acts via enzymatic production of kynurenine (Kyn) and signalling activity. The IFN- $\alpha$-protective effect in AIA was associated with both increased expression and enzymatic activity of IDO1 and the IFN- $\alpha$-protection was totally ablated in mice lacking IDO1 expression (IDO1 KO mice) and in mice treated with the inhibitor of the enzymatic activity of IDO1 (1-Methyl Tryptophan; 1-MT). Interestingly, administration of the IDO-metabolite Kyn protected mice from AIA in an IFNAR-independent manner. These observations show that the IDO1 enzymatic activity is important for the protective effect of IFN- $\alpha$. Using 1-MT, it was further shown that the enzymatic activity of IDO1 was, like TGF- $\beta$, crucial only at the sensitization but not in the arthritis phase of AIA for IFN- $\alpha$ to protect against arthritis. Instead, IDO1's non-enzymatic signalling activity, characterized by sustained expression of IDO1 and non-canonical NF-KB activation in PDCs, was observed in the arthritis phase in spleen cells from mice treated with IFN- $\alpha$. 
Regulatory T cells (Treg cells) were also found to be important for IFN- $\alpha$-protection in AIA. Transient depletion of Treg cells by diphtheria toxin in DEREG mice in the arthritis phase, but not during the sensitization phase abolished IFN- $\alpha$-protection. Treatment with IFN- $\alpha$ enhanced the numbers of Treg cells in the course of AIA and their function; compared to untreated mice, Treg cells isolated at day 10 and 20 of AIA from IFN- $\alpha$ - treated mice exhibited higher suppressive activity against mBSA-stimulated proliferation of responder $T$ cells. The enhancing effect of IFN- $\alpha$ on Treg cell numbers was observed in blood, spleen, LNs and also in ex-vivo cultures of leucocytes re-stimulated with mBSA and IFN- $\alpha$. Although IFN- $\alpha$ clearly increased the suppressive activity of Treg cells, adoptive transfer of Treg cells from mBSA immunized mice, regardless of IFN- $\alpha$ treatment, prevented the development of arthritis.

\section{Conclusion}

In the presence of IFN- $\alpha$ during antigen sensitization, a state of tolerance is established, which is able to prevent joint inflammation induced by antigenic re-challenge. This immunological tolerance is created in the sensitization phase of AIA and is characterized by inhibition of pro-inflammatory cytokines, increased TGF- $\beta$ production and activity of the IDO1 enzyme, the latter two being indispensable for IFN- $\alpha$-induced protection.

Administration of Kyn, the metabolite of the enzymatic activity of IDO1, in the sensitization phase also protected against AIA downstream of type I IFN signalling. In the arthritis phase regulatory $T$ cells, whose numbers and suppressive capacity was clearly enhanced by IFN- $\alpha$, mediate the actual prevention of arthritis development in IFN- $\alpha$-treated animals. We have thus identified molecular and cellular components of the anti-inflammatory program elicited by IFN- $\alpha$ including Kyn that may not have the pro inflammatory effects associated with IFN. 
CONTENTS

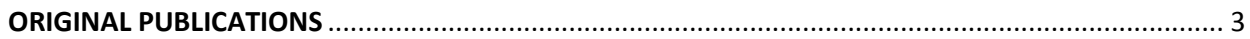

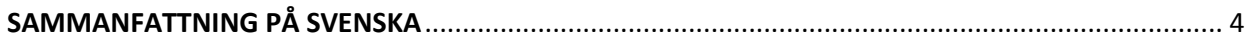

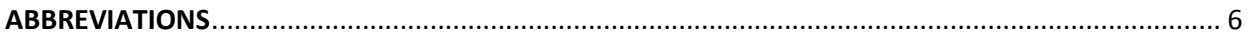

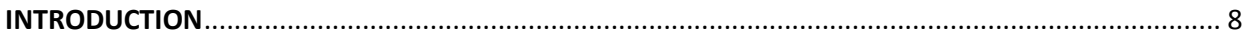

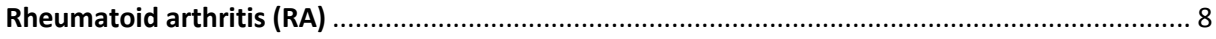

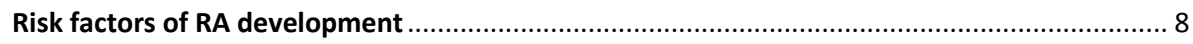

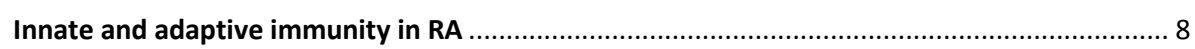

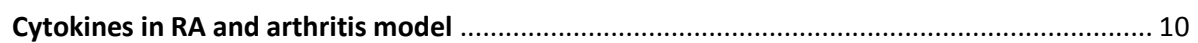

Current treatments of RA and the need of new treatment strategies ..................................... 11

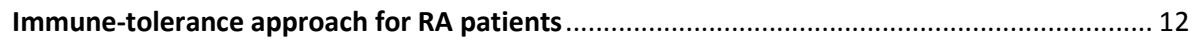

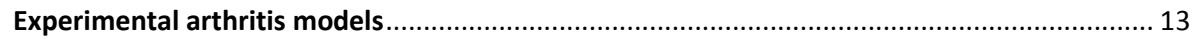

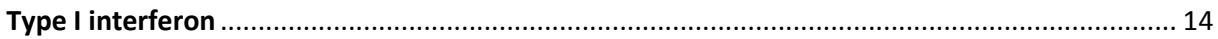

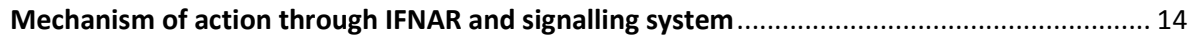

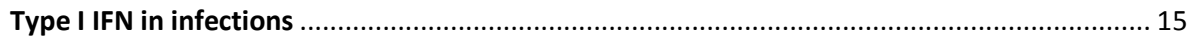

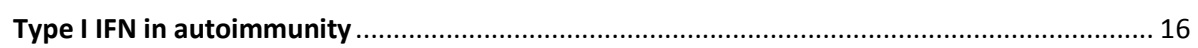

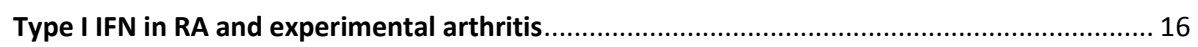

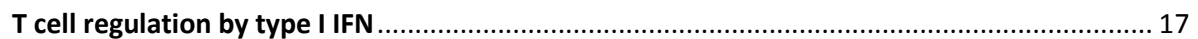

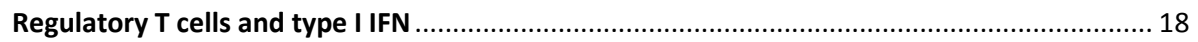

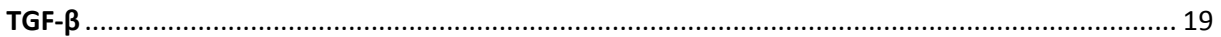

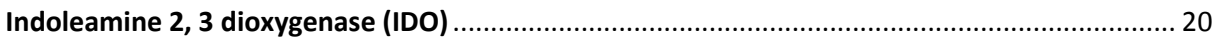

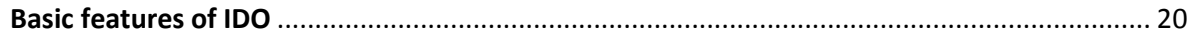

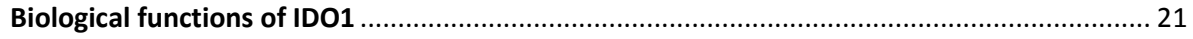

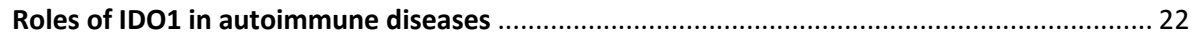

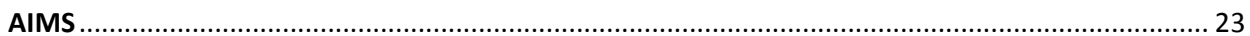

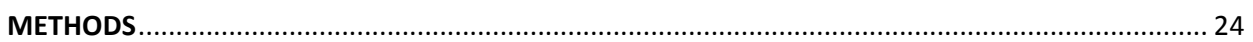

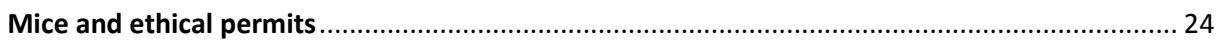

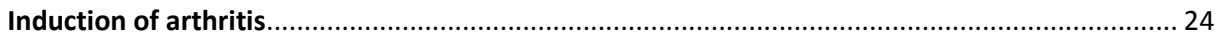

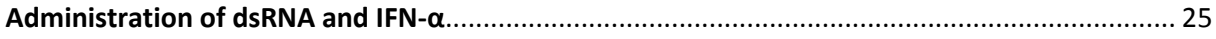

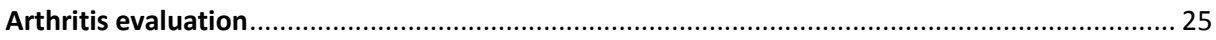

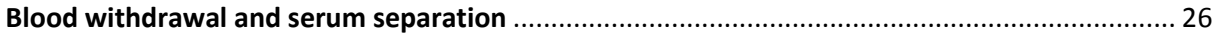

ELISA for the determination of mBSA-specific serum antibodies (Paper I and II) ......................... 26

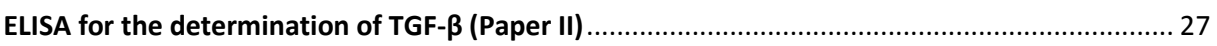

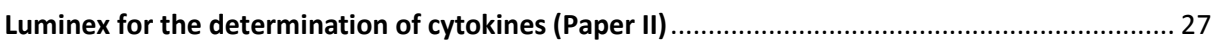

Cell proliferation assay by using ${ }^{3} \mathrm{H}$-Thymidine Incorporation assay (Paper I, II and III) ................ 28 
FACS Analysis

Determination of intra-cellular IFN- $\gamma$, IL-17 and TGF- $\beta$ in T cells and M $\phi$ s (paper II) .............. 28

Quantification of Treg cells in blood, spleens and LNs (Paper IV) ................................... 29

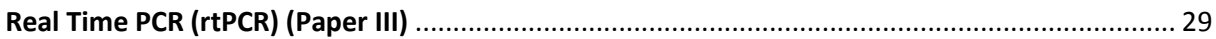

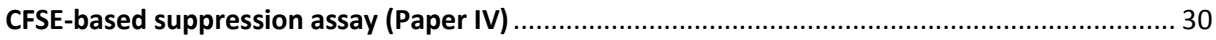

Tryptophan and Kynurenine determination (Paper III) ..................................................... 31

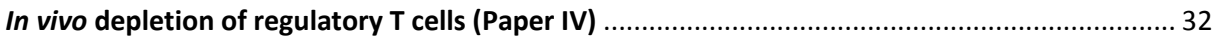

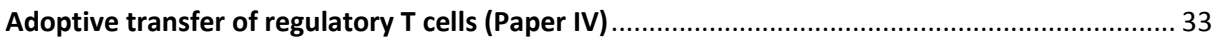

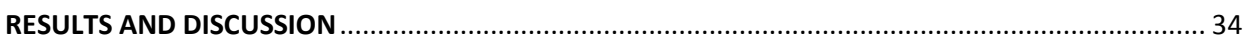

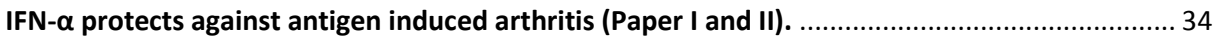

Effect of IFN- $\alpha$ on the humoral response during AIA: IFN- $\alpha$ has limited effect on humoral

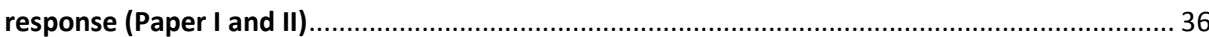

Effect of IFN- $\alpha$ on T cells during AIA: IFN- $\alpha$ inhibits antigen-specific leucocyte proliferation ex

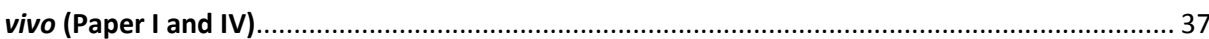

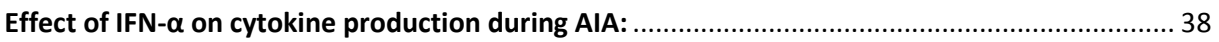

IFN- $\alpha$ inhibits pro-inflammatory cytokines but increases TGF- $\beta$ during AIA (Paper II)................ 38

The protective effect of IFN- $\alpha$ in AIA is mediated by TGF- $\beta 1$ (Paper III) .................................. 43

Indoleamine 2, 3 dioxygenase and IFN- $\alpha$-protection of AIA (Paper III) ................................. 44

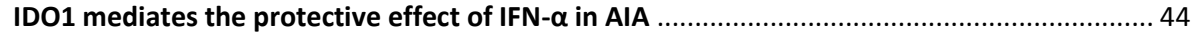

The enzymatic pathway versus signalling pathway of IDO1 during IFN- $\alpha$ protection of AIA .... 47 Kyn, the major IDO1 product, ameliorates arthritis (Paper III) .................................................. 50

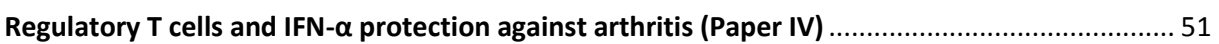

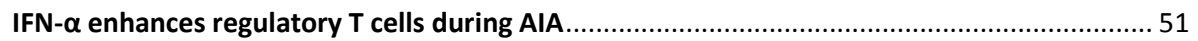

Regulatory T cells mediate the IFN- $\boldsymbol{\alpha}$-protection against AIA ......................................... 53

IFN- $\alpha$ treatment in vivo increases the in vitro suppressive activity of regulatory T cells ......... 54

Adoptive transfer of Treg cells from mBSA-immunized mice protects against mBSA-induced

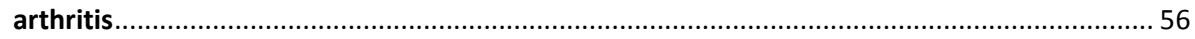

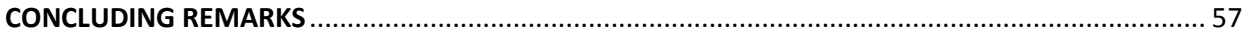

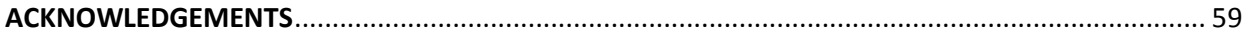

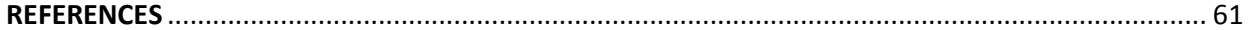




\section{ORIGINAL PUBLICATIONS}

\section{Manuscripts included in the thesis}

\section{Paper I}

Fei Ying, Jaya Prakash Chalise, Sudeep Chenna Narendra and Mattias Magnusson, (2011) Type I IFN protects against antigen-induced arthritis.

European Journal of Immunology. 41(6):1687-95.

\section{Paper II}

Jaya Prakash Chalise, Sudeep Chenna Narendra, Bhesh Raj Paudyal and Mattias Magnusson, (2013) Interferon alpha inhibits antigen-specific production of pro-inflammatory cytokines and enhances antigen-specific TGF- $\beta$ production in antigen-induced arthritis.

Arthritis Research \& Therapy. 15:R143.

\section{Paper III}

Jaya Prakash Chalise, Maria Teresa Pallotta, Sudeep Chenna Narendra, Björn Carlsson, Alberta lacono, Louis Boon, Ursula Grohmann and Mattias Magnusson, IDO1 and TGF- $\beta$ mediate protective effects of IFN- $\alpha$ in antigen-induced arthritis.

Manuscript submitted

\section{Paper IV}

Jaya Prakash Chalise, Sudeep Chenna Narendra, Sophie Biggs, Louis Boon and Mattias Magnusson, Regulatory T cells manifest IFN- $\alpha$ mediated protection during antigen induced arthritis.

Manuscript

\section{Relevant publications which are not included in the thesis}

Sudeep Chenna Narendra, Jaya Prakash Chalise, Fei Ying, Nina Almqvist and Mattias Magnusson, (2014) Dendritic cells activated by double-stranded RNA induce arthritis via type I IFN.

Journal of Leucocyte Biology. Apr; 95(4):661-6.

Sudeep Chenna Narendra, Jaya Prakash Chalise, Mattias Magnusson \& Srinivas Uppugunduri, Local but not systemic administration of uridine prevents development of antigen-induced arthritis.

PloS One. Accepted, 2015 


\section{SAMMANFATTNING PÅ SVENSKA}

Människokroppens försvar mot bakterier och virus bygger bland annat på en förmåga att känna igen små strukturer på sjukdomsalstarna, varvid en försvarsattack startar som slår ut bakterierna eller virusen - och vi tillfrisknar. Ibland gör kroppen dock fel och attackerar i stället sig själv, vilket leder till sjukdom.

Bland dessa sjukdomar märks t.ex. typ I diabetes där cellerna som gör insulin attackeras och ledgångsreumatism där lederna attackeras. Då immunförsvaret attackerar den egna kroppsvävnaden kallas dessa sjukdomar autoimmuna

Denna avhandling studerar hur immunsystemet kan instrueras att inte reagera med inflammation, dvs bli tolerant då det stöter på ett ämne som kan leda till en oönskad inflammation som t.ex. autoimmun sjukdom eller allergi.

Toleransutveckling studeras här i en artritmodell (artrit=ledinflammation) av den autoimmuna sjukdomen ledgångsreumatism och vi visar att cytokinet interferon-alfa (ett protein i kroppen) kan skydda mot uppkomst av ledinflammation (arbete I). Interferon-alfa tillhör de s.k. typ I interferonerna där flera alfavarianter och en betavatiant ingår som alla binder till och aktiverar samma cellytereceptor. Det är en grupp proteiner med svårdefinierbara egenskaper. Exempelvis så är typ I interferon tydligt anti-inflammatoriskt vid multipel skleros där det är en del av behandlingen men i andra sammanhang tros typ I interferoner bidra till inflammation, t.ex. vid den systemiska sjukdomen SLE.

För att vårt fynd att interferon-alfa kan förhindra uppkomst av ledinflammation skall kunna omsättas till behandling av oönskade inflammatoriska reaktioner måste de anti-inflammatoriska egenskaperna hos interferon-alfa identifieras och isoleras från de tydligt pro-inflammatoriska egenskaperna som rapporterats i andra sammanhang. Detta är det genomgående målet för studierna i denna avhandling.

Då interferonet skyddar mot artrit inhiberas frisättningen av en rad pro-inflammatoriska cytokiner såsom interleukin-1, 6, 12 och 17 och TNF, samtidigt som det anti-inflammatoriska TGF-beta aktiveras (arbete II). Genom att därefter inhibera TGF-beta förstod vi att denna aktivering är ett måste för att interferon skall kunna skydda mot artrit (arbete III).

En viktig molekyl för att skydda oss mot autoimmuna sjukdomar är indole-amine 2, 3 dioxygenase (IDO). Då IDO kan aktiveras av just TGF-beta och även av interferon-alfa valde vi att i detalj studera IDOs betydelse för skyddet mot ledinflammation. Genom att använda s.k. knock-out-möss som helt saknar IDO-enzymet fann vi att den skyddande effekten av interferon-alfa var helt beroende av IDO; mössen som saknade IDO kunde inte alls skyddas mot artrit med inteferonbehandling. Därefter visade vi att den enzymatiska aktiviteten hos IDO (att omvandla aminosyran Tryptofan (Trp) till Kynurenine (Kyn) är viktig för interferonets skyddande förmåga och att Kyn i sig kan skydda mot artrit om det tillförs på samma sätt som interferonet (arbete III).

Den artritmodell vi använder för att studera toleransutveckling inbegriper två s.k. immuniseringar (dag 1 och dag 7) där ett antigen (metylerat bovint serum albumin, mBSA) tillförs en mus. Till följd av detta får mössen inflammation i leden då samma antigen tillförs direkt i knäleden två veckor senare (dag 21). En vecka senare uppstår tydlig ledinflammation och för att interferon skall förhindra detta krävs att interferonet ges i samband med immuniseringarna, dvs. dag 1 och dag 7. Ges interferonet då själva artriten håller på att utvecklas så fås inget skydd (arbete I). Slutsatsen av detta är att behandlingen med interferon ger upphov till immunologisk tolerans. 
För att vidare studera när cytokinet TGF-beta och enzymet IDO bidrar till skyddet så varierade vi tidpunkten för då dessa molekyler inhiberades under artritutvecklingen. Detta gav oss att både signalering via TGF-beta och den enzymatiska aktiviteten hos IDO var är avgörande för möjligheten för interferon att skydda mot artrit, då immunsystemet kommer i kontakt med antigenet. Detta visades genom att inhibera IDO precis i början av artritmodellens förlopp. Om TGF-beta och IDO istället endast inhiberades under det att artriten börjar ta form (från dag 21), så hade det ingen effekt, dvs. IFN kunde fortfarande skydda mot artrit (arbete III).

Slutsatsen av detta är att interferon begagnar TGF-beta och IDO för att skapa tolerans mot ett antigen. När väl toleransen är skapad är det andra mekanismer än IDO och TGF-beta som förhindrar att inflammation uppstår då immunsystemet stöter på samma antigen igen.

Vi har också identifierat s.k. regulatoriska T-celler som avgörande för att interferon skall kunna skydda mot artrit. Till skillnad från IDO och TGF-beta så spelar alltså de regulatoriska T-cellerna en aktiv roll i att dämpa inflammationen då artriten börjar ta form (arbete IV).

Sammanfattningsvis så tror vi att interferon kan ge upphov till tolerans på följande sätt: Då immunsystemet kommer i kontakt med ett antigen, som potentiellt kan ge upphov till inflammationsgenererande T- celler, i närvaro av interferon-alfa, så aktiveras i stället ett antiinflammatoriskt program som gör att inflammationsgenererande T-celler inte uppstår.

Vid första kontakten med antigen plus interferon vet vi nu att det anti-inflammatoriska cytokinet TGF-beta aktiveras, som i sin tur kan aktivera enzymet IDO1. Aktivt IDO1 omvandlar vidare aminosyran Trp till Kyn. Samtliga dessa steg behövs för att interferon-alfa skall etablera det antiinflammatoriska programmet som gör att inflammation inte uppstår då immunsystemet kommer i kontakt med antigenet vid ett senare tillfälle.

I nästa steg, då en mus som behandlats med interferon vid immuniseringen med antigen, utsätts för antigenet igen (i leden), då aktiveras Treg som aktivt förhindrar inflammation. Exakt hur kopplingen mellan aktiveringen av TGF-beta följt av IDO-aktivering och omvandling av Trp till Kyn som sker vid första kontakten med antigen plus interferon-alfa är ännu inte klarlagd. Vidare återstår att förstå hur interferon-alfa, TGF-beta, IDO och Kyn kan aktivera regulatoriska T-celler och slutligen hur de regulatoriska T-cellerna verkligen gör för att förhindra inflammation.

Denna avhandling är en början på en beskrivning av hur interferon-alfa kan ge upphov till immunologisk tolerans. Den identifierade signalvägen via Kyn skulle framledes kunna bli ett medel för att utveckla tolerans och samtidigt undvika de pro-inflammatoriska biverkningarna av interferonalfa. 


\section{ABBREVIATIONS}

1-MT 1 Methyl DL Tryptophan

ACPA Anti-Citrullinated protein antibody

AIA Antigen induced arthritis

APC Antigen presenting cell

Breg cells Regulatory B cells

CCP Cyclic citrullinated peptide

CFA Complete Freund's adjuvant

CFSE Carboxyfluorescein diacetate succinimidyl ester

ConA Concanavalin A

CTLA-4 Cytotoxic T lymphocyte-associated antigen 4

$\mathrm{CIA} \quad$ Collagen induced arthritis

Cpm Count per minute

DC Dendritic cell

DT Diphtheria toxin

DMARD Disease-modifying anti-rheumatic drug

DMSO Dimethyl sulfoxide

dsRNA Double stranded RNA

EAE Experimental Autoimmune Encephalomyelitis

EDTA Ethylene diamine tetra acetic acid

ELISA Enzyme linked immunosorbent assay

FACS Fluorescence activated cell sorting

FBS Fetal bovine serum

FMO Florescence minus one

i.a. Intra-articular

IBD Inflammatory bowel diseases

IDO Indoleamine 2, 3 dioxygenase

IFN Interferon

IFA Incomplete Freund's Adjuvant

Ig Immunoglobulin

IL Interleukin

i.p. Intra-peritoneal

ISG IFN stimulated genes

Kyn Kynurenine

LAP Latency-associated protein

LCMV Lymphocytic choriomeningitis virus

LN Lymph nodes

MACS Magnetic-activated cell sorting

MBSA Methylated bovine serum Albumin

MFI Mean fluorescence intensity

MHC Major Histocompatibility complex 


\begin{tabular}{ll} 
MMP & Matrix metalloproteinase \\
M $\phi$ & Macrophage \\
MS & Multiple sclerosis \\
MTX & Methotrexate \\
PBS & Phosphate buffer saline \\
pDC & Plasmocytoid dendritic cell \\
Poly I:C & Polyinosinic:polycytidylic acid \\
PRR & Pattern recognition receptors \\
RA & Rheumatoid arthritis \\
RF & Rheumatoid factor \\
RT & Room temperature \\
RBC & Red blood cell \\
S.C. & Sub-cutaneous \\
SLE & Systemic lupus erythematous \\
STAT & Signal transducer and activator of transcription \\
TCR & T cell receptor \\
TGF- $\beta$ & Transforming growth factor- $\beta$ \\
Th cell & T helper cell \\
TLR & Toll-like receptor \\
TNF & Tumour necrosis factor \\
Teffect & Effector T cell \\
Treg cell & Regulatory T cell \\
Tresp cell & Responder T cell \\
Trp & Tryptophan \\
WT & Wild type \\
\hline
\end{tabular}




\section{INTRODUCTION}

\section{Rheumatoid arthritis (RA)}

RA is a common autoimmune disease characterized by swelling of joints with synovial inflammation, cartilage and bone destruction, and autoantibody production including rheumatoid factor (RF) and anti-citrullinated protein antibody (ACPA). It is often associated with systemic complications like cardiovascular, pulmonary, skeletal disorders and psychological (McInnes and Schett, 2011).

\section{Risk factors of RA development}

Genetic risk factors are associated with RA. The most studied group of genes associated with RA is the major histocompatibility class II genes (MHC-II) belonging to the human leucocyte antigens (HLA-DRB1) and exposing the shared epitope (SE). Carriage of HLA-DRB1/SE infers a 3-5\% increased relative risk of developing RA among non-smokers. Cigarette smoking infers a greatly enhanced ( $>20$-fold) relative risk to develop ACPA-positive RA among HLA-DRB1/SE positive individuals (Klareskog et al., 2006). Furthermore, alleles associated with T cell activation for e.g. PTPN22, AFF3, CTLA-4, CD28, CD40, IL-2, STAT-4 and alleles associated with NF-kB pathway are also reported to be linked with RA (Mclnnes and Schett, 2011). Overall, the average prevalence of RA is 2-3 times higher in women than in men. However, the female predominance diminishes considerably with increasing age (Englund et al., 2010). The changed pattern in hormones in female during pregnancy and menopause is one presumed explanation for this difference (Costenbader and Manson, 2008).

Apart from cigarette smoking, other environmental factors in RA pathogenesis include, e.g. bacterial and viral components like CPG DNA, dsRNA, and peptidoglycans in synovia and synovial fluids (van der Heijden et al., 2000, Bokarewa et al., 2008). In recent years, the interest in a role of mucosal bacteria in RA pathogenesis has increased, especially regarding the oral pathogen Porphyromonas gingivalis and it's potential to citrullinate proteins (Rutger Persson, 2012). In addition to infectious microbes, the interest in an association between normal microbial flora and RA is also increasing (Scher and Abramson, 2011). How microbial agents play a role in the pathogenesis of RA is still not properly understood, but is a field of intense research (Catrina et al., 2014).

\section{Innate and adaptive immunity in RA}

Innate immunity includes non-specific first line defense mechanisms that come into play immediately after an antigen's appearance in the body. Presence of dendritic cells (DCs), macrophages (M申), mast cells, natural killer cells and neutrophils in the synovial membrane or synovial fluid of RA patients confirm the involvement of innate immunity during the pathogenesis of RA (Tak and Bresnihan, 2000). DCs, a major antigen presentation cell type, 
activates adaptive immunity through differentiation of naïve T cells to effector T cells with the help of specific cytokines and co-stimulatory molecules. In addition to activating the immune system, DC also have a role in maintaining immune tolerance against harmless antigens, including those from the body's own tissues. DC may have a pathogenic role in RA as Abatacept, a drug blocking the co-stimulation process between antigen presenting cells (APC) and T cells, is an effective treatment for RA. Similarly, the other antigen presenting cells, the Mфs are best known to be associated with RA, as they produce several proinflammatory cytokines such as TNF, IL-1 $\beta$, IL-6 and matrix proteinases that further activate inflammation in the joints.

Accumulation of T cells in the synovium, and the genetic association to HLA-DRB1/SE are indications of T-cell involvement in RA. This suggestion was confirmed by several studies showing that T-cell depletion ameliorates the severity of inflammation in murine models of arthritis (Alzabin and Williams, 2011). However, the report that T cell depletion by monoclonal antibodies had very limited effect in RA complicates the role of T cells in RA (Alzabin and Williams, 2011).

T cells are of different types, mainly helper T cells (Th cells), cytotoxic T cells, suppressor T cells and gamma delta T cells. Th cells themselves can be divided into several distinct subtypes, mainly Th1, Th2, Th17 and regulatory T cells (Treg cells). Earlier, RA was believed to be driven mainly by Th1 cells, but after the discovery of Th17 cells, both Th1 and Th17 are considered important in RA (Mellado et al., 2015). The cytokines produced by these cells, i.e., IFN- $\gamma$ and IL-17 play major roles in modulating RA (discussed in next section). Contrary to the pathogenic T cells, Treg cells which are anti-inflammatory, might have protective roles in RA. Depletion of Treg cells in mice aggravates the severity of experimental arthritis, whereas adoptive transfer $\mathrm{CD} 4^{+} \mathrm{CD} 25^{+}$cells protects against arthritis (Frey et al., 2005). In humans also, functional abnormalities of Treg cells have been identified in RA patients (Flores-Borja et al., 2008, Cribbs et al., 2014)

B cells are the lymphocytes which, after antigen activation, can be transformed to plasma cells that produce antigen-specific immunoglobulins (antibodies) of different isotypes (IgM, IgD, IgG (subclasses 1-4), IgA (subclass 1 and 2), and IgE. Rituximab, a B-cell blocking drug, has been found effective to treat RA. This suggests that $B$ cells are pathogenic in RA. The $B$ cells in the synovium of RA patients may be involved in the local production of RF and ACPA, activation of T cells, and the production of pro-inflammatory cytokines (Bugatti et al., 2014). The importance of RF and ACPA during pathogenesis of RA is not clear yet, however it is believed that they form immune complexes in the joint which activate complement system. The activated neutrophils/Mфs upon ingestion of immune complex can release proteases and oxidative free radicles that aggravates the inflammation in the joints (Cedergren et al., 2007). Recently, strong evidence has been presented indicating that RF and ACPA have pathogenic importance for the bone loss/bone erosions in joints of patients with RA (Kleyer et al., 2014, Kocijan et al., 2013, Hecht et al., 2014). 
In the collagen induced arthritis model, antibodies against citrullinated proteins enhance tissue injury suggesting the importance of $B$ cells in the pathogenesis of autoimmune arthritis (Kuhn et al., 2006). In fact, arthritis is mediated via B cells and anti-collagen type II (anti-CII) antibodies also in the animal arthritis models "K/BxN" (antibodies to glucose- 6 phosphate) and collagen antibody-induced arthritis (CAIA) respectively.

\section{Cytokines in RA and arthritis model}

Cytokines are small proteins produced mainly by immune cells, which mediate immune cellto-cell interactions. Based on their role in inflammation they can be roughly divided in three major categories i) pro-inflammatory cytokines, ii) anti-inflammatory cytokines and iii) immune-modulatory cytokines. The cytokines TNF, IL-1ß, IL- 6 and IL-17 are considered as the prototype pro-inflammatory cytokines whereas IL-10 and IL-35 are regarded as the major anti-inflammatory cytokines. The remaining cytokines can be regarded as immunemodulatory cytokines as they have roles in inflammation but the roles cannot be plainly defined as pro or anti-inflammatory. The biological effects of each cytokine vary depending on dose, context of disease and inflammation status indicating that all cytokines have some degree of pleotropic nature.

Cytokines are directly or indirectly involved in the pathogenesis of RA. Numerous cytokines are found to be functionally active in the synovial area and also systematically altered in RA patients. Some of the important cytokines that have already been targeted for treatment of RA are:

\section{Tumor necrosis factor (TNF)}

TNF is a pro-inflammatory cytokine produced mainly by M $\phi$ s and T cells. In RA, TNF is involved in the activation of leucocytes and synovial fibroblast, production of other proinflammatory cytokines like IL-1 and IL-6, chemokines and matrix enzymes, suppression of Treg cells, activation of osteoclasts and resorption of cartilage and bone (Moelants et al., 2013). Biological drugs based on the inhibition of TNF activation pathway for example Adlumubab, Enercept, Golimumab, and Infliximab are found effective in treatment of RA.

\section{IL-16}

IL-1 $\beta$ is a prototype pro-inflammatory cytokine required for inflammasome activation. IL-1 $\beta$ is counterbalanced by IL-1 $\beta$ receptor antagonist which binds competitively to the IL-1 $\beta$ receptor. During RA, IL-1 $\beta$ is known to activate leucocytes, induce matrix enzyme production, and increase the number of synovial fibroblast and endothelial cells and also to activate osteoclasts. Anakinra, a monoclonal human antibody against IL-1 $\beta$ is an approved drug for RA patients (Kay and Calabrese, 2004). 


\section{IL-6}

IL-6 is a pleotropic cytokine that activates T cells, differentiates B cells to plasma cells and differentiates naïve T cells to Th17 cells in presence of TGF- $\beta$. Excess production of IL- 6 is found in the synovial fluid and blood of RA patients. Furthermore, it is known to activate osteoclasts, increase matrix metalloproteinase (MMP) and C-reactive protein (CRP) production, which all lead to synovitis. Tocilizumab, a humanized anti-IL-6R antibody is found effective in RA patients and is approved for the treatment of RA and systemic juvenile idiopathic arthritis (Md Yusof and Emery, 2013).

\section{IL-17}

IL-17 is a pro-inflammatory cytokine, produced mainly by Th17 cells but also by Mфs during inflammatory conditions (Song et al., 2008). It binds to IL-17 receptor (IL-17R) which is expressed in immune cells, epithelial cells and fibroblasts. Activation of IL-17R leads to production of other inflammatory cytokines such as IL-6, IL-1 $\beta$, TNF, and GM-CSF and chemokines like CXCL3, CCL3 and CCL2 which initiate inflammation by recruiting neutrophil, lymphocytes, and Mфs (Gaffen, 2008). In RA, IL-17 has been reported to induce MMPs, increased synovial fibroblasts, chondrocytes, and increase osteoclastogenesis (Roeleveld and Koenders, 2015). A monoclonal antibody against IL-17, Secukinumab (human anti-IL-17A monoclonal antibody) is currently in a phase III clinical trial for the treatment of RA patients (Genovese et al., 2013).

Similarly, other cytokines like type I IFNs, IL-12, IL-21, IL-10 and TGF- $\beta$ are reported to be connected to RA directly or indirectly. However their roles in the pathogenesis RA has not been clearly established yet. (Type I IFN and TGF- $\beta$ are discussed in next sections).

\section{Current treatments of RA and the need of new treatment strategies}

Nowadays, it is well established that RA should be diagnosed as early as possible, in order to initiate disease-modifying anti-rheumatic drug (DMARD) treatment, thereby preventing chronic tissue damage and disability. Glucocorticosteroids, which indeed have potent antiinflammatory effects, are not included among the DMARDs. However, a series of recent studies demonstrated that they indeed have disease-modifying properties (Svensson and Hafstrom, 2011, Hafstrom et al., 2009, Hafstrom et al., 2014). Yet high-dose and long-term therapy with corticosteroids is avoided due to the risk of side effects. Among the traditional DMARD therapies, low-dose methotrexate (MTX) is nowadays usually the drug of choice. To avoid cytotoxic effects of MTX (like folate inhibition), the patients are substituted with folic acid. Like for most anti-rheumatic drugs (including biologics), the mechanism(s) explaining the anti-rheumatic effect of MTX has not been settled, but it's induction of adenosine release (anti-inflammatory by binding to adenosine A2A receptors) is plausible (Hasko and Cronstein, 2013). In addition, since the turn of the century, a large (and still growing) number of biological DMARDs (mainly monoclonal antibodies, and fusion proteins) have 
been introduced and revolutionized anti-RA therapy (Kiely et al., 2012). These drugs target pro-inflammatory cytokines, and molecules exposed on cell surfaces cells (e.g. cytokine receptors, CD20 on B-cells, and CD80/86 on antigen-presenting cells). Clinical and preclinical studies are ongoing for drugs targeting kinase based intracellular-signalling molecules (Bonilla-Hernan et al., 2011).

Though the modern concepts of anti-rheumatic therapy have considerably improved RA care, they are still associated with problems such as unresponsiveness to therapy, loss of efficacy over time, adverse effects including infections, and high costs. TNF inhibitors and many other biologicals indeed increase the risk of Tuberculosis infection, but not in many patients (Winthrop, 2006). So, novel strategies for an ideal drug candidate for RA are still the subject of active research.

\section{Immune-tolerance approach for RA patients}

Immune-tolerance can be defined as the physiological process by which the immune system recognizes but does not, or only to a minimal extent, attack harmless foreign antigens or self-antigens. RA being an autoimmune disease, induction of immune-tolerance against arthritogenic antigen would be the ideal strategy for controlling RA. This strategy can leave the immune system intact to fight against infectious agents or any other dangers, while at the same time preventing immune attacks against arthritogenic antigens (Garber, 2014). Various types of immune-activating cells like T cells, B cells, DCs and M $\phi$ s are in fact also known to have their immune-regulatory counterparts term Treg cells, regulatory B cells, regulatory DCs and suppressor $M \phi s$ respectively. All of these cells can contribute to immune tolerance and are therefore good therapeutic targets to induce antigen-specific tolerance. In fact, these regulatory cells have shown promising results in experimental models of arthritis (Mauri and Carter, 2009, Burmester et al., 2014). However, the cellular microenvironment consisting of cytokines, chemokines and other protein/non-protein immune mediators, is crucial for these cells to exhibit tolerogenic properties. The functions of these cells are dynamic in nature, and can switch from immunogenic to tolerogenic, or vice versa, depending on the cellular microenvironments. For example, plasmocytoid DCs and T cells turn to a tolerogenic phenotype in the presence of TGF- $\beta$ and IL-10, whereas the presence of IL-6 switches them to a pathogenic phenotype (Pallotta et al., 2011, Jego et al., 2003). Hence, novel immune-mediators, which can modulate immune cells from an immunogenic to a tolerogenic function against arthritogenic antigens should be identified to apply antigenspecific tolerance approach for RA therapeutics.

In animal arthritis models, antigens that induce arthritis are well defined for e.g. collagen type II in CIA and methylated-BSA in AIA. In humans, however, the disease-inducing autoantigens are not yet properly defined, which makes the application of antigen-induced tolerance difficult. Hence, it is first essential to identify the antigen and immune surrogate markers for application of tolerogenic approaches for RA. 


\section{Experimental arthritis models}

Animal models of RA provide invaluable tools to understand the basic biological process of arthritis development, and to identify novel molecular pathways and targets during the pathogenesis of the disease. Although no model takes into account all the aspects of human RA, there are several animal models that develop similar features of RA, and several of these models have been successfully used for evaluation of novel therapeutic agents. Commonly used arthritis models are collagen-induced arthritis (CIA), the K/BxN model, and antigeninduced arthritis model (AIA) applied in the present thesis work. $\mathrm{ClA}$ is the most commonly used model where arthritis is induced in DBA/1 mice by intradermal injection of an emulsion consisting Freund's complete adjuvant and bovine type II collagen which is followed by a booster dose after 21 days that initiates inflammation in collagen rich tissues. Though all joints develop some form arthritis, hind paws are significantly affected with visible swellings and synovitis. Another common model is the $\mathrm{K} / \mathrm{BxN}$ model in which mice are crossed to coexpress T cell receptor (TCR) transgene KRN and the MHC class II alleleAg7 that result in development of arthritis. The serum of these mice when transferred to recipient mice also develop arthritis due to autoantibodies recognizing glucose-6-phosphate isomerase (GPI) (Monach et al., 2008).

Antigen-induced arthritis, also sometimes called adjuvant induced arthritis (AIA), is a T cell mediated arthritis model where arthritis is induced by local injection of antigen in an already hyper-sensitised animal in the presence of an adjuvant. Methylated bovine serum albumin ( $m B S A)$ is the commonly used antigen to induce AIA. This model was first developed in rabbit, then translated to rats and mice (Brackertz et al., 1977). Unlike other models, arthritis can be induced in several strains of mice and the inflammation is confined to the antigen injected joints which makes it possible to compare arthritic biochemical and structural changes in AIA with a normal contra-lateral joint. This model has characteristic features similar to RA like presence of synovial cell infiltration, cartilage destruction and synovial lining hyperplasia. In this model, antigen specific antibodies can be detected in serum after 10 days which increase significantly with time. However, there are some limitations of this model while comparing to pathophysiology of RA. In RA, if left untreated, the inflammation in the joint may continue to aggravate that may lead to severe bone destruction, however in AIA the induced inflammation in the joint subsides with time (van den Berg et al., 2007). Furthermore, arthritis develops in AIA as a result of induced immunogenicity against external mBSA. Hence, AIA does not recapitulate the endogenous breach of tolerance which is a major hallmark for the pathogenesis of autoimmune diseases including RA.

Several others arthritis models for example collagen antibody induced arthritis, Zymosaninduced arthritis, TNF transgenic mouse model of inflammatory arthritis also exist (Asquith et al., 2009) 


\section{Type I interferon}

Interferons (IFNs) are pleotropic cytokines which were initially discovered as interfering substances against the influenza virus (Isaacs and Lindenmann, 1957). Later these virusinterfering substances were named IFNs and were further classified as three different groups: type I IFN, type II IFN (IFN- $\gamma$ ), and the recently discovered type III IFN named IFN- $\lambda$ (IL-28 and IL-29). The type I IFN family consists of IFN- $\alpha$, IFN- $\beta$, and poorly characterized IFN-

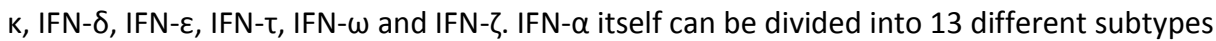
(14 subtypes in mice) (McNab et al., 2015).

All cells are capable of producing type I IFN e.g., during a viral infection, however IFN- $\alpha$ and IFN- $\beta$ are produced to a larger extent by pDCs and fibroblasts respectively. When microbial components like nucleic acids ( $\mathrm{CpG}$ oligodeoxynucleotides and RNA) and liposaccharides activate pattern recognition receptors (PRR) present in membranes and cytoplasm of host cells, type I IFN production can be activated. For example, the PRRs TLR3, TLR7/8 and TLR9 are activated by double stranded RNA, certain forms of single stranded RNA (ssRNA) and CpG DNA respectively, which all may stimulate the production of type I IFN. Likewise TLR2, TLR4, RIG1 and MDA5 activation by viral ligands, LPS and RNA are also involved in type IIFN production. In general, the activated PRR leads to recruitment of adaptor molecules (MyD88, TIRAP, TRAM, and TRIF) that activate few interferon regulatory factors (IRF) which finally process the transcription of IFN- $\alpha$ and IFN- $\beta$ (McNab et al., 2015). The production of type I IFN can be amplified by a positive feedback loop, where the early produced type I IFN induce transcription of certain IRFs in DCs, leading to transcription of more IFN genes (Tailor et al., 2007).

In addition to microbial stimulation, type I IFNs are also reported to increase in several autoimmune diseases like RA and systemic lupus erythematosus (SLE) (Theofilopoulos et al., 2005). However, it is not clear weather IFN production is initiated by microbial products or by some other mechanism in those diseases. In SLE, it is believed that excess apoptosis results in increased load of self-derived DNA or ribonucleoproteins complexed by IgG-class autoantibodies. These nucleic-acid containing immune-complexes when endocytosed by Mфs or pDCs, can be recognized by endosomal Toll-like receptor 7 and 9 leading to type I IFN production (Banchereau and Pascual, 2006, Bave et al., 2003, Lovgren et al., 2004). In RA and experimental allergic encephalomyelitis (EAE), already produced immune mediators like TNF and receptor activator of nuclear factor kappa B ligand (RANK-L) might contribute to type I IFN production (Yarilina et al., 2008, Takayanagi et al., 2002)

\section{Mechanism of action through IFNAR and signalling system}

All type I IFNs bind to a common receptor called the type I IFN receptor (IFNAR) that is expressed by all immune cells and is composed of two subunits IFNAR1 and IFNAR2. IFNAR1 is associated with tyrosine kinase 2 (TYK2) where as IFNAR2 is associated with Janus activating kinase (JAK) kinase. Binding of the receptor by IFN- $\alpha$ or IFN- $\beta$ causes activation of 
JAK that can phosphorylate signal transducer and activator of transcriptions (STATs): STAT1, STAT2, STAT3, STAT5 and STAT6 as homodimers or heterodimers with several combinations of STATs. The activated STAT homodimers or heterodimers then bind to interferon stimulated response element (ISRE) sites or gamma activated sequence (GAS) sites in the promoter regions of IFN stimulated genes (ISGs) (Platanias, 2005). In addition to the STAT pathways, type I IFN can also active other signalling pathways like mitogen activated protein kinase pathways and PI3K pathways (Kaur et al., 2005). Hence, binding of type I IFN to the IFNAR receptor can activate several STAT dependent or independent signalling pathways leading to the production of hundreds of diverse ISG genes resulting in a variety of biological outcomes.

\section{Type I IFN in infections}

As mentioned earlier, one established function of type I IFN is to induce an anti-viral state in both virus infected and non-infected cells. Based on this antiviral property, IFN- $\alpha$ has been successfully used therapeutically to treat several viral infections including hepatitis $B$ and chronic hepatitis C (Pestka et al., 2004). Type I IFN induces antiviral states by multiple mechanisms: i) restricting viral replication through stimulation of several ISGs encoding antireplicating proteins, ii) enhancing activation of DCs, natural killer (NK) cells and M申s, iii) Promoting $\mathrm{CD}^{+}$and $\mathrm{CD} 8^{+} \mathrm{T}$ cell responses, iv) enhancing $\mathrm{B}$ cell responses that increase the production of neutralizing antibodies (Yan and Chen, 2012). However, type I IFNs do not always have anti-viral effects. Recent studies suggest that type I IFN can be detrimental for chronic viral infections, as blockage of type I IFN signalling resulted in effective clearance of persistent lymphocytic choriomeningitis virus (LCMV) (Teijaro et al., 2013, Wilson et al., 2013). This effect of type I IFN in chronic viral infections is associated with its antiinflammatory property, which also increases the expression of immunosuppressive genes, such as interleukin-10 (il-10) and programmed cell death 1 ligand 1 (pdl1). (The antiinflammatory properties of type I IFN is discussed below).

Type I IFN is also produced in significant amounts during bacterial infections. However, their actual role during bacterial infection is not obvious as type I IFN can be both protective and detrimental to the host during bacterial infection. In infections by the Chlamydia family, and species of Salmonella, Legionella, Helicobacter, E coli and Streptococci, type I IFN plays a protective role possibly by activating Th1 immunity (McNab et al., 2015). It is also believed that type I IFN, by activating Indoleamine 2, 3 dioxygenase (IDO), reduces the availability of the essential amino acid tryptophan to intracellular pathogens, which restricts proliferation of the pathogens. However, during infection with Listeria monocytogenes, Mycobacterium tuberculosis and Francisella tularensis, type I IFN has been reported to have detrimental effects, possibly due to type I IFN mediated suppression of pro-inflammatory cytokines, especially IL-1 $\beta$ (McNab et al., 2015). 


\section{Type I IFN in autoimmunity}

Autoimmunity can be defined as clinical syndromes developed due to inappropriate activation of the immune system, resulting in damage to one or multiple organs (Davidson and Diamond, 2001). Mechanisms of autoimmunity are partially understood. For instance, it could be due to imbalances between effector and regulatory components of the immune system (Bluestone, 2011). A growing body of evidence confirms the involvement of type I IFN in modulating autoimmune diseases, however the nature of its involvement remains complicated as type I IFN may be associated both to detrimental and protective effects depending on the disease context. Type I IFN and its main producer pDCs are considered detrimental in SLE (Ronnblom and Pascual, 2008). Sustained high levels of type I IFN as well as type I IFN stimulated gene expression are found in SLE patients. This might be due to an increased load of immune complexes containing nucleic acid. The pathogenic role of type I IFN in SLE might be due to sustained IFN- $\alpha$-mediated maturation of plasma cells producing autoantibodies, which again leads to type I IFN production. Similarly, high levels of type I IFN are seen in psoriasis, which is a T cell mediated chronic inflammatory skin disease. Here, IFN$\alpha$ produced by PDC triggers local activation and proliferation of pathogenic $T$ cells, which in turn leads to uncontrolled differentiation of keratinocytes (Nestle et al., 2005).

In contrast to SLE and psoriasis, type I IFN has anti-inflammatory effects in intestinal bowel diseases (IBD) and multiple sclerosis (MS). Mice lacking type I IFN receptor are extremely susceptible to dextran-sulphate sodium (DSS)-induced colitis, and external administration of Type I IFNs and ligands of TLR3 and TLR9 protect against colonic injury and inflammation in models of experimental colitis (Gonzalez-Navajas et al., 2012, Katakura et al., 2005a). With these promising results in animals, both IFN- $\beta$ and IFN- $\alpha$ have been tested in IBD patients, but without beneficial therapeutic effect (Gonzalez-Navajas et al., 2012). However, in MS, IFN- $\beta$ treatment is beneficial both in humans and in Th1- but not Th17-mediated experimental models of MS (Axtell et al., 2010). Currently, IFN- $\beta$ is a regular therapeutic drug for MS patients. The protective effect of type I IFN in MS and experimental intestinal diseases are attributed to type I IFN ability to induce IL-10 and also to enhance the number and function of Treg cells (Gonzalez-Navajas et al., 2012).

\section{Type I IFN in RA and experimental arthritis}

Many early studies reported an increase of type I IFNs in serum or in synovial fluid, and induction of type I IFN gene signature expression in RA patients (Hooks et al., 1979, Shiozawa et al., 1986, Hopkins and Meager, 1988, Gattorno et al., 2007, Sigurdsson et al., 2007, Roelofs et al., 2009). However, these studies did not reveal whether or not type I IFN contributes to aggravate or to alleviate the inflammation. It is possible that the increased levels of type I IFN and signature have a counter-protective role in RA. Taking into the account, the anti-osteoclast property of type I IFN, it is possible that the bone erosion process is decreased in patients with high type I IFN signature (Mensah et al., 2010). Also by inhibiting IL-1 $\beta$, but enhancing IL-1 receptor antagonist (IL-1RA), type I IFN can alleviate 
inflammation. Actually, in in vitro cultures of synovial tissue from RA patients it was seen that the levels of IL-1 receptor antagonist (IL-1RA) were raised in the presence of IFN- $\alpha$ (Wong et al., 2003). Similarly, after IFN- $\beta$ treatment of RA patients, reduction in synovial $\mathrm{CD}^{+} \mathrm{T}$ cells and the expression of MMP-1, TIMP-1, IL-6, IL-1 $\beta$ was observed in synovial tissue (Smeets et al., 2000). However, others have reported that RA like symptoms developed in patients receiving IFN- $\alpha$ treatment (Passos de Souza et al., 2001, Nadir et al., 1994). Also dsRNA, a potent inducer of type I IFN, has been found in synovial fluid of RA patients (Bokarewa et al., 2008). The pathogenic role of type I IFN is further supported by the studies which shows that Borreila induced lyme-arthritis is associated with increased IFN gene expression signature and blockade of type I IFN reduced the development of arthritis (Miller et al., 2008). In agreement with these studies, previous study from our lab showed that dsRNA, when injected in knee joints induce arthritis that is dependent of type I signalling (Magnusson et al., 2006).

In experimental models of arthritis, the majority of studies support the anti-inflammatory property of type I IFN. IFN- $\beta$ in pure form or IFN- $\beta$ secreting fibroblast or IFN- $\beta$ gene therapy ameliorates CIA in mice (van Holten et al., 2004, Triantaphyllopoulos et al., 1999) and rhesus monkeys (Tak et al., 1999) and also in K/BxN arthritis model (Corr et al., 2009). Similarly, dsRNA or IFN- $\alpha$, when given in the effector phase of antibody-induced arthritis, protects against arthritis in a type I IFN dependent manner (Yarilina et al., 2007). These type I IFN mediated protective effects might be due to the inhibitory effect of type I IFN on proinflammatory cytokines TNF, IL-6, IL-1 $\beta$ and on osteoclasts (van Holten et al., 2002). Though the pre-clinical studies and a small cohort clinical studies were promising for IFN- $\beta$, in the larger clinical studies, IFN- $\beta$ was not found to be beneficial against RA (van Holten et al., 2005, Genovese et al., 2004, Tak et al., 1999).

Hence, all these observations suggests that type I IFN has the ability to modulate the pathogenesis of arthritis both in humans and animals, though the nature of modulation can be debatable. The observed effects of type I IFN on arthritis might be through its ability to alter the function of various immune cells like T cells and antigen presenting cells, which are crucial in the pathogenesis of arthritis.

\section{T cell regulation by type I IFN}

Type I IFN has a prominent direct or indirect influence on T cells. One mechanism of type I IFN for antiviral effect is through the enhancement of primary and memory $\mathrm{CD} 4^{+}$and $\mathrm{CD} 8^{+} \mathrm{T}$ cells (Crouse et al., 2015). During viral infection, type I IFNs can increase the proliferation, survival and differentiation by directly acting on IFNAR of T cells and indirectly through activation and maturation of antigen presenting cells (Crouse et al., 2015). However, type I IFN also induces anti-proliferative and pro-apoptotic programs in T cells by inducing program death I receptor (PD-1) (Terawaki et al., 2011). This divergent effect (pro- and anti-T cells) of type I IFN on T cells may depend upon the relative timing of activation of IFNAR and T cell 
receptor (TCR) signalling. It is believed that type I IFN exhibits pro-T cells effects when TCR activation coincides or precedes IFNAR activation whereas when IFNAR are activated before TCR activation, type I IFN exhibits anti-T cells effects (Crouse et al., 2015). The effect of type I IFN on effector Th cells also differs with the context, but considering the majority of studies in humans and mice, it can be inferred that type I IFN has enhancing effect on Th1 cells whereas inhibitory effect on Th2 and Th17 cells (Huber and Farrar, 2011).

\section{Regulatory T cells and type I IFN}

The immune system should be tightly regulated in order to maintain tolerance against selftissue and to prevent tissue damage due to immune activation during infection. Several regulatory immune cell types are important for maintaining central and peripheral tolerance of which regulatory $T$ cells are the major cell type. Basically, three types of regulatory $T$ cells, i.e., type I regulatory T cells (Tr1), Th3 cells and Foxp $3^{+} T$ cells have been described that can dampen immune reactions (Jonuleit and Schmitt, 2003). Tr1 cells and Th3 cells produce and utilize immune-regulatory cytokine IL-10 and TGF- $\beta$ respectively to control immune activation. The third and the most studied regulatory $T$ cells are the $\mathrm{CD}^{+} \mathrm{T}$ cells that express high levels of the alpha subunit of IL-2 receptor called CD25. These cells (CD4 ${ }^{+} C D 25^{+}$) were first described by Sakaguchi and co-workers in 1995 in a seminal paper where they showed that blocking of these cells leads to development of autoimmune disorders (Sakaguchi et al., 1995). As CD25 receptor can be present in effector T cells and B cells, scientists were sceptical about the specificity of these suppressive T cells. In 2003, a transcription factor called Forkhead box protein 3 (Foxp3) was identified as lineage specifying factor for $\mathrm{CD} 4{ }^{+} \mathrm{CD} 25^{+}$cells and this Foxp3 is now considered as specific marker for $\mathrm{CD} 4^{+} \mathrm{CD} 25^{+}$to distinguish from previously described Tr1 and Th3 cells which are devoid of Foxp3 expression (Fontenot et al., 2003). Foxp3 controls the gene encoding IL-2 and other genes encoding proinflammatory cytokines at the same time activates CD25 and CTLA-4. Scurfy mice lacking the Foxp3 gene develops severe lymphoproliferative autoimmune disease, which highlights the importance of Foxp3 in maintenance of self-tolerance (Sakaguchi et al., 2008). Substantial studies in the last two decades established Foxp $3^{+} \mathrm{CD}^{+} \mathrm{T}$ cells as the most important immune regulators of the immune system, whose defects in function and quantity might lead to development of autoimmunity, allergy and other immune-pathological disorders (Josefowicz et al., 2012). (The Treg cells mentioned below refer to CD4 ${ }^{+} \mathrm{CD} 25^{+}$Foxp3 $\mathrm{T}^{+}$cells unless stated otherwise.)

Treg cells have been divided in many ways depending on the origin of development, functional activity and activation status, which has often confused scientists. To simplify the classification, a group of senior immunologists recently proposed a novel way of subdividing $\mathrm{CD}^{+}{ }^{+}$oxp $^{+}$Treg cells into three groups:

i) Thymus-derived Treg cells (tTreg, previously called nTreg cells), 
ii) peripherally derived Treg cells (pTreg, previously called adaptive or induced Treg cells), and

iii) in vitro induced Treg cells (iTreg) (Abbas et al., 2013).

As mentioned, the main function of Treg cells is to maintain immune tolerance by controlling aberrant T cell proliferation. Treg cells exert suppressive effects by multiple pathways. The most established ones are by:

i) Production of soluble anti-inflammatory cytokines like IL-10, TGF- $\beta$, and IL-35.

ii) Cell contact mechanism: CTLA-4 from Treg cells ligate to B7/CD80 of antigenpresenting cells, which prevent the co-stimulation of T cells via CD28- B7/CD80 ligation. Furthermore, CTLA-4-B7/CD80 ligation leads to induction of IDO and Forkhead box $\mathrm{O3}$ (Foxo3) molecule. IDO exerts immune suppression by multiple pathways (discussed in later section). Foxo3 is an immune regulating transcription factor that inhibits cytokine production by DCs (Wing and Sakaguchi, 2010).

iii) By inhibiting maturation of DC through interaction of lymphocyte activation gene on Tregs cells with MHC II molecules on DCs (Liang et al., 2008).

iv) Increasing the consumption of IL-2, which is needed for proliferation of effector T cells (Thornton and Shevach, 1998)

The impact of type I IFN on Treg cells are not clear as the existing studies show diverse, often opposite effects of type I IFN on Treg cells depending on disease and experimental context (Piconese et al., 2015). In MS patients, EAE and experimental colitis, type I IFN favours the differentiation as well as functional suppressive capacity of Treg cells (Katakura et al., 2005b, Lee et al., 2012, Chen et al., 2012). This pro-Treg effect is supported by studies of Mellor and his group where they showed that CpG-DNA, a potent type I IFN inducer, activates IDO1 in splenic CD19+DCs which enhances Treg cell functions through type I IFN signalling (Mellor et al., 2005). Further, they showed that this activation of IDO in those subgroups of DCs results in cell-autonomous IFN- $\alpha$ production, which in turn can re-activate IDO, sustaining the Treg cells function (Manlapat et al., 2007). In contrast to these enhancing effect of type I IFN on Treg cells, type I IFN directly inhibits Treg cells during LCMV infection (Srivastava et al., 2014). Similarly, in SLE patients as well as in patients with graft versus host disease, type I IFN was reported to inhibit Treg cell proliferation and its suppressive function (Le Buanec et al., 2011, Bacher et al., 2013).

\section{TGF- $\beta$}

Transforming growth factor beta is a family of peptides (TGF $\beta 1$, TGF $\beta 2$, TGF $\beta 3$ ) that are synthesized by several cell types, including platelets, mast cells, neutrophils, monocytes, endothelial cells, M $\phi$, fibroblasts, and keratinocytes (de Gorter et al., 2011). Initially, it is synthesized in an inactive form composed of a TGF- $\beta$ dimer in association with the latencyassociated protein (LAP). TGF- $\beta$ becomes activated after the engagement of a TGF- $\beta$ 
activator that triggers LAP degradation or alters LAP conformation in response to environmental prerequisites. Active TGF- $\beta$ binds to a complex receptor of TGF- $\beta$ RI \& TGF$\beta R I I$ and initiates kinase-dependent signalling pathways. TGF- $\beta$ has multiple effects in the immune system, including maintenance of $\mathrm{T}$ cell homeostasis and immune-tolerance (Li et al., 2006). However, in the presence of IL-6, TGF- $\beta$ promotes the differentiation of naïve Th cells to pathogenic Th17 cells.

TGF- $\beta$, being an important regulator of immune tolerance, is both directly and indirectly connected to autoimmune diseases. TGF- $\beta$ exhibits protective effects in experimental models of SLE and EAE (Raz et al., 1995, Li et al., 2006). The effect of TGF- $\beta$ on RA is dependent on the context of administration. Systemic administration of TGF- $\beta$ ameliorates experimental arthritis (Brandes et al., 1991), whereas local administration aggravates arthritis (Allen et al., 1990). Later studies suggest that TGF- $\beta$ induces regulatory T cells and inhibition of Th17 are reasons for the TGF- $\beta$ mediated protection against experimental arthritis (Park et al., 2011). One possible immune-regulatory mechanism of TGF- $\beta$ during inflammation is through induction and activation of IDO1 (Belladonna et al., 2011, Pallotta et al., 2011).

\section{Indoleamine 2, 3 dioxygenase (IDO) \\ Basic features of IDO}

Indoleamine 2-3 dioxygenase (IDO) is a cytosolic enzyme that catalyse the first and ratelimiting step of the amino acid DL tryptophan (Trp) conversion to kynurenines (Sugimoto et al., 2006). Kynurenines are a set of similar compounds e.g., xanthurenic acid, kynurenic acid, 3-hydroxykynurenine, and kynurenine (Kyn) formed during IDO1 mediated Trp metabolism. IDO is coded by a highly conserved Ido gene (chromosome location: 8p12-p11 human and 8 A2; $12.76 \mathrm{cM}$ mouse). Recently, a paralogue of Ido gene called Ido2 (location 8p11.21 human and $8 \mathrm{~A} 2 ; 12.58 \mathrm{cM}$ mouse) was discovered and coined as IDO2, hence the firstly described IDO was later named IDO1. The detailed biological features and functions of IDO2 are yet to be explored.

IDO1 is constitutively expressed at sites of infection, tumours, chronically inflamed tissues, intestinal tract, and maternal-fetal interfaces (Kahler and Mellor, 2009). At the cellular level, antigen-presenting cells (in particular DCs), and Mфs contain large amounts of IDO1 (Kahler and Mellor, 2009). Normally expressed at low levels, IDO1 is rapidly induced during inflammatory situations. Interferons (type I and II) and inducers of type I IFN e.g., CpG, are known IDO1 inducers (Puccetti, 2007). In fact the promoter regions of Ido1 gene contains Interferon Stimulated response elements (ISRE) and Gamma interferon associated sites (GAS) (Paguirigan et al., 1994, Dai and Gupta, 1990). 
IDO1 is also induced after the interaction of CTLA-4 molecules of regulatory T cell with B7 molecules of DCs. In addition to IFNs, other immune mediators such as TNF, IL-10, TGF- $\beta$, TLR ligands and prostaglandin E2 are also known to induce IDO1 (Kahler and Mellor, 2009).

\section{Biological functions of IDO1}

Consumption of the essential amino-acid Trp is an ancestral strategy to control microbial growth. The same strategy is utilized by mammalians to control aberrant T-cell proliferation where they use IDO1 to consume Trp from the surrounding environment leading T cells to death by Trp starvation. In 2001, Munn and Mellor showed that treating mice with 1 methyl tryptophan (1-MT), a competitive inhibitor of IDO1, resulted in T-cell mediated rejection of semi-allogenic, but not syngeneic fetus rejection (Mellor et al. 2001). This finding explained how the fetus is protected from strong maternal immune attacks and placed IDO1 as an important player for immune-tolerance. After this discovery, intense research has been performed regarding IDO1's role in autoimmune diseases, cancer and transplantation medicine. IDO1 is now considered as a key molecule for immune suppression and immunetolerance (Curti et al., 2009, Katz et al., 2008).

IDO1 might exert immune-suppression by multiple mechanisms. The first one is via consumption of the essential amino-acid Trp, which leads to Trp starvation among proliferating T cells and ultimately the proliferation ceases (Mellor and Munn, 2004). Later it has been discovered that Trp-starvation triggers a response mediated by a kinase called general control nonderepressible 2 (GCN2) that shuts down cell cycle progression of T cells (Munn et al., 2005). The second mechanism of IDO1 mediated immune suppression is via the Kynurenines which are cytotoxic to T cells (Fallarino et al. 2003; Frumento et al. 2002). Several in vitro studies suggest that IDO1 favours the Treg cells' differentiation and activation (Fallarino et al., 2006, Mellor et al., 2005, Baban et al., 2005, Sharma et al., 2007). One possible mechanism of enhancement of Tregs cells by IDO1 might be through Kyn. Kyn, a major stable metabolite of IDO1 is an active ligand of aryl hydrocarbon receptor (AHR) which, upon activation, induces regulatory T cells and inhibits Th17 cells (Nguyen et al., 2010).

Recently, a new mechanism of immune-regulation by IDO1 was discovered, which is independent of its enzymatic activity. In response to TGF- $\beta$, IDO1 initiates an intracellular signalling pathway in pDC leading to a stable tolerogenic pDCs (Pallotta et al., 2011). In this signalling pathway, TGF- $\beta$ phosphorylates inhibitory tyrosine based motif (ITIM) of the IDO1 enzyme which then interacts with suppressor of cytokine signalling 3 (SOCS3), and further initiates the downstream signalling system of non-canonical NFkB and SHPs. Activation of non-canonical NFkB and SHP sustains the levels of TGF- $\beta$ and type I IFN which maintains long term tolerance (Pallotta et al., 2011). 


\section{Roles of IDO1 in autoimmune diseases}

As mentioned before, IDO1 has been reported to be important in a number of autoimmune diseases (Munn and Mellor, 2013). In mice, deletion of the IDO1 gene or inhibition of IDO's enzymatic activity by 1-MT does not result in spontaneous development of symptoms of autoimmune inflammation. This indicates that IDO1 is not essential for maintaining selftolerance. However, IDO1 deficiency or inhibition leads to aggravation of experimental models of arthritis or MS (Yan et al., 2010, Zhu et al., 2006, Criado et al., 2009, Szanto et al., 2007b). In contrast, IDO1 induction by gene therapy leads to amelioration of collageninduced arthritis in rats (Chen et al., 2010). Furthermore, IDO1 has been shown to be a critical mediator for the function of several immunomodulatory substances known to protect against several autoimmune diseases (Park et al., 2014, Lee et al., 2013, Park et al., 2012, Huang et al., 2012). In RA, IDO1 might become activated, as several studies showed increased serum Kyn/Trp ratio or decreased serum Trp levels of RA patients (Williams, 2013). However, arthritis was in fact found improve after inhibition of IDO activity by 1-MT before induction of arthritis in the K/BxN model, where arthritis is induced by antibodies against the glucose- 6 phosphatase isomerase (Scott et al., 2009). The pathogenic property of IDO1 in this model is attributed to IDO1's enhancing role of pathogenic B cells (Scott et al., 2009). Therefore IDO1 might not be the universal immune suppressor in inflammation. 


\section{AIMS}

The overall aim of this thesis is to increase our understanding about how type I IFN protects against antigen-induced arthritis (AIA).

Specific aims of the papers:

- Paper I: to examine the effect of dsRNA and type I IFN on development of arthritis in AIA.

- Paper II: to analyse the optimal dose of IFN- $\alpha$ needed to protect against AIA and to analyse IFN- $\alpha$-mediated modulation of cytokines and humoral immunity during AIA.

- Paper III: to analyse the role of TGF- $\beta$, IDO1 and its downstream pathway in IFN- $\alpha$ protection against AIA.

- Paper IV: to analyse the role of regulatory T cells during IFN- $\alpha$-protection against AIA. 


\section{METHODS}

\section{Mice and ethical permits}

SV129EV mice and IFNARKO mice were bought from B and K universal, North Humberside England. IDO1KO, LysM Cre ${ }^{+}, \mathrm{Tgfb}^{\mathrm{fl} / \mathrm{fl} l}$ and Foxp3DTReGFP mice were from Jackson Laboratories, Maine, USA. Mice were further bred in the Animal facility unit of Linköping University. For IDO1KO and Foxp3DTReGFP strains, heterozygous mouse pairs (mutated gene in one allele) were bred, which produce mutant (homozygous: mutated gene in both alleles, $I d o 1^{-/}$), wild type ( $\mathrm{wt}, I d o 1^{+/+}$) and heterozygous (ht, Ido $1^{+/-}$) offspring. The offspring were genotyped (using ear tissue) to distinguish the mutant and wild type according to the protocol by Jackson Laboratories. Wt littermates were used as control mice. LysMCre ${ }^{+}$and $T g f b 1^{f l / f l}$ mice were crossbred to produce LysM Cre ${ }^{+/-} \mathrm{Tgfbr} 2^{f / / f l}$. Cd4-Cre ${ }^{+/-}$Ifnar ${ }^{f / f l}$ and Cd4$\mathrm{Cre}^{-/-}$Ifnar ${ }^{f l / f l}$ was provided on a collaborative basis from Professor Ulrich Kalinke at the Centre for Experimental and Clinical Infection Research, Twincore, Hannover, Germany.

In all experiments (unless mentioned otherwise), female mice aged 8-12 weeks were used. All experimental procedures were performed strictly according to the guidelines provided by the Swedish Animal Welfare Act and approved by the Ethical Committee Board in the regional court of Linköping (Ethical no 72-2009, 77-09, 12-01) and in Stockholm South (N271-14).

\section{Induction of arthritis}

The methylated bovine serum albumin (mBSA) induced arthritis model was used according to principles described by Van den Berg et al. (van den Berg et al., 2007) (Fig. 1). (note: the term Antigen Induced Arthritis (AIA) is used to indicate mBSA-induced arthritis in this thesis). In this model, at day 1, mice are sensitised subcutaneously (s.c) in the left flank with $200 \mu \mathrm{g}$ mBSA emulsified in incomplete Freund's adjuvant (IFA). For preparation of the emulsion, the mBSA was diluted in phosphate buffered saline (PBS) and mixed 1:1 (volume) with Freund's incomplete adjuvant using two syringes connected to each other with a 3-way stopcock. Then, the piston is moved vigorously until a white, viscous emulsion is formed. At day 7 , the mice were booster sensitised with $100 \mu \mathrm{g}$ of mBSA (prepared similarly to the first sensitisation). During booster sensitisation $50 \mu \mathrm{l}$ of $\mathrm{mBSA}$ emulsion was injected s.c. in each side of the base of the tail. At day $21,30 \mu \mathrm{g}$ of mBSA in $20 \mu \mathrm{l}$ volume was injected in the left knee joints. $20 \mu \mathrm{l}$ of PBS was injected in the right knee for control. 


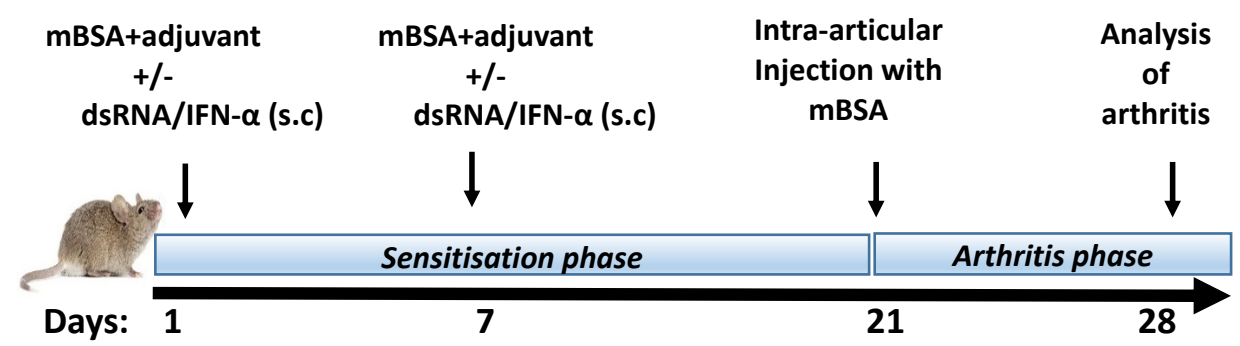

Figure 1. Representative scheme of mBSA-induced arthritis model (AIA).

\section{Administration of dsRNA and IFN- $\alpha$}

DsRNA and type I IFN was administered at day 1 and 7 of AIA (Fig. 1). The dsRNA analogue poly I:C (Sigma-Aldrich, St. Louis, USA), $200 \mathrm{mg}$ on day 1 and $100 \mathrm{mg}$ on day 7, was mixed to the antigen emulsion prepared for sensitisation of AIA (see above). Similarly, recombinant murine IFN- $\alpha A$ (100-5000 U) (PBL, Interferon Source, Piscataway, USA) was administrated in the same manner as dsRNA at day 1 and 7. In some experiments, $1000 \mathrm{U}$ of IFN- $\alpha$ was administered by intra-peritoneal injection on day 21. (Note: unless mentioned otherwise, IFN- $\alpha$-treatment refers to administration of 1000 U IFN- $\alpha$ at day 1 and 7 of AIA in all the experiments described in the thesis)

\section{Arthritis evaluation}

At day 28 of AIA, mice were sedated with isoflurane and killed by cervical dislocation. The knee joints were removed and fixed in 4 percent buffered formaldehyde (Histolab, Sweden) for 7-10 days. The joints were then decalcified with mixture of formic acid and sodium carbonate, dehydrated and embedded in paraffin. Sagittal sections $(4-5 \mu \mathrm{m})$ of the joints were prepared and stained with hematoxylin (Sigma-Aldrich) and eosin (Sigma-Aldrich). The severity of arthritis was evaluated by 2-3 independent persons through microscopic observation of the blindly coded joint sections. It was scored from 0 to 3 considering the magnitude of three parameters: synovial thickening, infiltration of cells in the synovial cavity and cartilage and bone erosion of the knee joint (Fig. 2). Scores: 0-Normal joints, 1-Mild inflammation, 2-Moderate inflammation, 3-Severe inflammation. When scores differed between observers, the section was re-evaluated by the observers together to a final consensus score. A score of 1 or more of the joint section was considered to be an arthritic joint. 
Normal Knee joint (Arthritis score-0)

Arthritic Knee joint (Arthritis score-3)

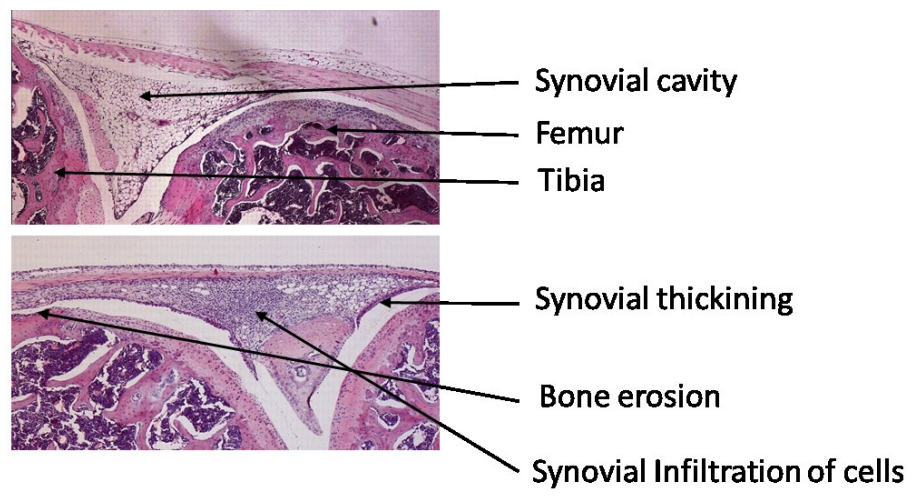

Figure 2. Representative histological slides (magnification 40X) of knee joint collected at day 28 of AIA describing the parameters considered to evaluate the severity score of arthritis.

\section{Blood withdrawal and serum separation}

At different days of AIA, around 50-200 $\mu$ l of blood was taken from the tail. For this purpose, the mice were sedated with isoflurane, warmed under the heating lamp for some time. Before regaining consciousness, a small cut was made with the scalpel at the lower side of the tail. Few drops of the blood were collected in an eppendorf tube. For serum collection, after 1-2 hours of room incubation, the blood was centrifuged at $5000 \mathrm{G}$, the serum was separated and stored at $-20^{\circ} \mathrm{C}$ until further analysis. For FACS analysis of blood cells, the collected blood was immediately mixed with 50-100 $\mu \mathrm{l}$ of heparin solution and processed for FACS analysis (see below).

\section{ELISA for the determination of mBSA-specific serum antibodies (Paper I and II)} MBSA-specific IgG (total, IgG1, IgG2a, IgG2b), IgA and IgE were determined in serum by Enzyme Linked Immunosorbent Assay (ELISA). Briefly, 96-well flat-bottomed NUNC ELISA plates were coated overnight at $4^{\circ} \mathrm{C}$ with mBSA $(10 \mu \mathrm{g} / \mathrm{ml})$ diluted in $50 \mathrm{mM}$ bicarbonate/ carbonate buffer. The plate was blocked with $200 \mu \mathrm{l}$ of $2 \%$ casein (Sigma-Aldrich) in each well for $2 \mathrm{hr}$ in room temperature or overnight at $4^{\circ} \mathrm{C}$. Serum samples were diluted in casein buffer 1:500 for determination of total IgG, IgG1, IgG2a, and IgG2b, and 1:20 for determination of IgA and IgE. $100 \mu \mathrm{l}$ of diluted serum samples were added in triplicates and incubated for 2 hours. Then $100 \mu$ of horseradish peroxidase (HRP)-conjugated secondary antibody goat (anti-mouse total IgG, IgG1, IgG2a, IgG2b, IgE (Bethyl Laboratories, Montgomery, AL, USA) and rat anti-mouse IgA (Southern Biotech, Birmingham, AL, USA) was added and the plate was further incubated for 2 hours. The antibodies were diluted in casein buffer at the concentration as specified for ELISA by the manufacturer. In each step washing was performed 3 times with phosphate-buffered saline (PBS) $+0.05 \%$ Tween-20. The plate was developed by adding $100 \mu$ l of tetra 3,3',5, 5'-tetramethylbenzidine (TMB (Sigma) 
solution, followed by incubation (dark) for 10-15 minutes. Finally, the reaction was stopped with $50 \mu \mathrm{l} 1 \mathrm{M} \mathrm{H}_{2} \mathrm{SO}_{4}$, and the developed colour was quantified by determining absorbance at $450 \mathrm{~nm}$ by an ELISA reader (Versa max Microplate Reader).

\section{ELISA for the determination of TGF- $\beta$ (Paper II)}

The levels of transforming growth factor-beta 1 (TGF- $\beta 1$ ) in serum collected at various days of AIA and in supernatants from ex vivo stimulated leucocytes were analysed using ELISA kit (eBioscience, San Diego, USA) according to manufacturer's instructions. Briefly, NUNC microtiter plates were coated overnight at $4{ }^{\circ} \mathrm{C}$ with capture antibody diluted in coating buffer. The plates were blocked for an hour at room temperature using the assay diluent. Latent TGF- $\beta 1$ was activated by addition of $1 \mathrm{~N} \mathrm{HCl}$, incubated for 10 minutes at room temperature and neutralized by addition of $1 \mathrm{~N} \mathrm{NaOH}$. A dilution factor of 1:100 was used for serum samples and 1:4 for supernatant samples (the dilution factor was determined by optimization experiments). Standards of recombinant TGF- $\beta 1$ with concentration ranging from $8 \mathrm{pg} / \mathrm{ml}$ to $1000 \mathrm{pg} / \mathrm{ml}$ were prepared according to manufacturer's instruction. All samples were incubated overnight at 4 으. Detection antibody was then added, and the plates were further incubated for one hour at RT, after which Avidin-horseradish peroxidase was added to the plates. Before each step, the plates were washed six times in PBS- $0.5 \%$ Tween 20. Plates were then developed after 30 minutes by the addition of substrate solution containing $\mathrm{TMB}$ and the reaction was stopped using $1 \mathrm{~N} \mathrm{H}_{2} \mathrm{SO}_{4}$ after 10 minutes and absorbance of the colour developed was analysed by ELISA reader. The concentration values were then determined according to the four parameter logistic regression standard curve.

\section{Luminex for the determination of cytokines (Paper II)}

The levels of cytokines in serum or in supernatants from ex vivo antigen-stimulated splenocytes and lymph node cells were determined by bead array technology. This is a new multiplexing technology based on the principle of conventional ELISA. Unlike ELISA, by this technology 100 different proteins (cytokines, chemokines etc) can be quantified simultaneously from a small sample volume. In this method, the sample is mixed with combinations of microscopic beads (colour-coded) which are pre-coated with capture antibodies to specific proteins of interest. Upon addition of sample, different proteins (cytokines in our case) bind to the cytokine-specific beads. This is followed by the addition of biotinylated detection antibodies specific to the cytokines, which forms an antibody-antigenantibody sandwich attached to beads. Phycoerythrin (PE)-conjugated streptavidin is then added which binds to detection antibodies and the beads are detected with a dual laser machine. The first laser classifies the specific bead, which determines the cytokine that is being detected. The second laser determines the intensity of PE signal, which is proportional to the quantity of cytokine bound to the beads.

We determined IL-1- $\beta$, IL-6, IL-17, IL-12 (p70), IFN- $\gamma$, TNF, IL-10 and IL-13 in serum collected at day $0,14,21$ and 28 and in supernatants from ex vivo antigen-stimulated splenocytes and 
lymph node cells collected after 48 hours culture by Multiplex Luminex kit (Bio-Rad Laboratories Inc. USA). The procedure was followed strictly according to the protocol provided by the company. The analytes were read by Luminex-200 machine (Invitrogen) and the data analysis was done with MasterPlex 2010 (version 5.0.0.68).

\section{Cell proliferation assay by using ${ }^{3} \mathrm{H}$-Thymidine Incorporation assay (Paper I, II and III)}

The thymidine incorporation assay is a common simple method to analyse cell proliferation. This method utilizes a strategy where a radioactive nucleoside $3 \mathrm{H}$-thymidine is incorporated into the newly synthesized chromosomal DNA during cell proliferation. The radioactivity in DNA recovered from the cells is measured by scintillation beta-counter. The magnitude of radioactivity (count per minute, $\mathrm{cpm}$ ) corresponds to the extent of cell division that has occurred.

At various days of AIA, the spleens and draining lymph nodes (axillary, brachial, popliteal, inguinal) were collected, crushed gently and passed through a $70 \mu \mathrm{m}$ nylon cell strainer to make a single cell suspension. RBC content of the spleen cell suspension was lysed by addition of RBC lysing solution (Sigma-Aldrich) according to the manufacturer's instructions. The cells were re-suspended in Iscove's Modified Dulbecco's Media (Sigma-Aldrich) supplemented with $10 \%$ heat inactivated fetal bovine serum (Sigma-Aldrich), $4 \mathrm{mM}$ glutamine (Sigma-Aldrich), $50 \mu \mathrm{M} \beta$-mercaptoethanol (Sigma-Aldrich), $100 \mathrm{U} / \mathrm{ml}$ penicillin, and $0.1 \mathrm{mg} / \mathrm{ml}$ streptomycin (Sigma-Aldrich). $2 \times 10^{5}$ cells in a total volume of $200 \mu \mathrm{l}$ were cultured in triplicates in the presence of media (for mock stimulation) or mBSA ( $50 \mu \mathrm{g} / \mathrm{ml}$ ) or Concavalin A $(0.1 \mu \mathrm{g} / \mathrm{ml})$ or anti-CD3 antibody $(1 \mu \mathrm{g} / \mathrm{ml})$. This concentration $(50 \mu \mathrm{g} / \mathrm{ml})$ of mBSA was chosen based on several optimization experiments which gave significantly higher proliferation than mock stimulation compared to lower concentrations of mBSA (data not shown). After 48 hours, the cells were pulsed with radioactive thymidine ( ${ }^{3} \mathrm{H}$-thymidine) (Perkin-Elmer, US) in the final concentration of $0.5 \mu \mathrm{Ci}$ per well and further cultured for 20 $24 \mathrm{hrs}$. Cells were then harvested on a filtermat that captures DNA and the beta emission (cpm) was then measured in a beta counter. The proliferation was expressed as mean cpm \pm SEM value where the corresponding mock (medium) cpm value was subtracted. In some experiments, after 48 hours of splenocyte or LN cell culture, 75-100 $\mu$ l of the supernatant was separately collected for analysis of cytokine production before pulsing cultures with radioactive thymidine.

\section{FACS Analysis}

\section{Determination of intra-cellular IFN- $\gamma$, IL-17 and TGF- $\beta$ in T cells and M\$s (paper II)}

At day $0,14,21$ and 28 during AIA, spleen and draining lymph nodes were isolated and single cells suspension was prepared in media as described in thymidine proliferation assay (see above). $5 \times 10^{5}$ cells were then re-stimulated ex vivo with medium, $\mathrm{mBSA}(50 \mathrm{\mu g} / \mathrm{ml})$ and antiCD3 $(1 \mu \mathrm{g} / \mathrm{ml})$ for 24 hours. Brefeldin A $(5 \mu \mathrm{g} / \mathrm{ml})$ and monensin $(1 \mu \mathrm{g} / \mathrm{ml}$, Biolegend, San 
Diego, USA) were added 5 hrs before harvest. Cells were re-suspended in FACS buffer (PBS containing 0.5 percent FBS), blocked with anti-mouse CD16/32 (Biolegend, San Diego, USA) and surface stained with anti-CD4-FITC (Milteyeni Biotech, Lund, Sweden), anti-F4/80-AF700 (AbD serotec, Dusseldorf, Germany), diluted according to the manufacturers recommendations. For intracellular staining the cells were further fixed and permealised with intracellular staining buffer set (eBioscience, San Diego, USA) according to the manufacturer's instructions and stained with anti-IFN- $\gamma$-APC (Biolegend, San Diego, USA), anti-IL-17A-PE (Biolegend, San Diego, USA) and anti-TGF- $\beta$-BV (Biolegend, San Diego, USA) diluted according to the manufacturer's recommendations. Between each step above, cells were washed three times with FACS buffer. The cells were anlaysed with FACS Gallios (Beckman Coulter, Inc.) and data were analysed with Kaluza ${ }^{\circledR}$ Flow Analysis Software, Beckman Coulter, (version 1.2). The percentages of IFN- $\gamma$, IL-17A, and TGF- $\beta$ positive cells among CD4 and $\mathrm{F} 4 / 80$ positive cells were determined by FMO gating as earlier described (Perfetto et al., 2004).

\section{Quantification of Treg cells in blood, spleens and LNs (Paper IV)}

Blood was collected from the tail at day 0, 4, 10, 14, 20, 24 and 28 from mice during AIA and mixed with heparin to prevent coagulation. $100 \mu$ of heparinized blood was surface stained with rat anti-mouse CD4 FITC antibody (BD Biosciences, San Jose, CA, USA) and rat antimouse CD25 antibodies (eBioscience, San Diego, CA, USA). Then the cells were fixed and permeabilized with Foxp3 staining set (eBioscience, San Diego, CA, USA) according to the manufacturer's instructions. The cells were stained intra-cellularly with rat anti-mouse Foxp3 and rat anti-mouse CTLA-4 antibodies (eBioscience, San Diego, CA, USA ) and were analysed with FACS Gallios (Beckman Coulter, Inc., Brea, United States) and collected data were analysed with Kaluza ${ }^{\circledR}$ Flow Analysis Software, Beckman Coulter, (version 1.2). The percentages of Foxp3 or CTLA-4 positive cells among gated CD4 ${ }^{+}$cells were determined by Floroscence minus one (FMO) gating as earlier described (Perfetto et al., 2004).

The spleens and a pool of draining lymph nodes (axillary, popliteal and inguinal) were collected at day $0,4,10,24$ and 28 of AIA. Single cell suspension was prepared by gently crushing the spleen and lymph nodes and passing through a $70 \mu$ m nylon cell strainer. Red blood cells were lysed using RBC lysing solution (Sigma-Aldrich, Dusseldorf Germany). Then the splenocytes and lymph nodes cells were stained separately with CD4, CD25, Foxp3 and CTLA-4 antibodies as described above for blood.

\section{Real Time PCR (rtPCR) (Paper III)}

Messenger RNA (mRNA) expression of IDO1 in spleen and draining lymph nodes was analysed at different time points of AIA. Spleens and lymph nodes from day 0, 4, 9, 14, 21 and 28 of AIA were collected and stored in RNA later (Sigma-Aldrich) until analysis. Total RNA was extracted using TRIZOL reagent (Sigma-Aldrich). Briefly, homogenized spleen or LNs were mixed with TRI reagent solution Trizol (Ambion) and BCP (1-Bromo-3 Chloropropanol, 
Molecular Research Centre) and incubated in RT for 5 minutes followed by centrifugation. The aqueous phase was then separated and mixed with isopropanol and $1 \mu$ of Glycoblue (Ambion) that results in coloured precipitation of RNA. The precipitated RNA was separated, washed 4 times with $70 \%$ ethanol and re-suspended in RNAase free water (Quiagen). The concentration of RNA was determined by measuring absorption $(260 \mathrm{~nm}$ ) by NanoDrop (ND-1000 spectrophotometer, Life Science Technologies). Then 20 ng of freshly extracted RNA was converted to CDNA with reverse transcription kit (Life technologies, California) according to manufactures' instructions. Real-time PCR was performed using universal PCR mastermix and specific TaqMan primer probes from Life technologies, (primer probes: Ido1: Mm 00492586_m1, Actin6: Mm 00607939_s1) on a ABI Prism 7500 fast PCR machine (Applied Biosystems). Actin $\beta$ was used as an endogenous reference gene. All the samples along with the naive control and no-template control were run in duplicates. $\Delta \mathrm{Ct}$ values were calculated as the difference of mean Ct values of ActinB gene and IDO1 gene. Then the relative expression of IDO1 was calculated using $2^{-\Delta \Delta C t}$ method by normalizing with $\Delta \mathrm{Ct}$ values of spleen or LN from naïve mice (Livak and Schmittgen, 2001).

\section{CFSE-based suppression assay (Paper IV)}

CFSE-based suppression assay is a common way to determine suppressive capacity of Treg cells by measuring the intensity of Carboxyfluorescein Succinimidyl Ester (CFSE) stained cells. In this assay, cells are first incubated with the cell-permeable compound Carboxyfluorescein Diacetate Succinimidyl Ester (CFDA-SE) which immediately diffuses evenly into the cytosol. Within the cytosol, CFDA-SE converts into CFSE, which is a stable, fluorescent, non-cell permeable molecule. When a CFSE-stained cell divides, the amount of CFSE also divides into half. So, the fluorescent signal from CFSE in each original cell decreases proportionally with the times of division (Quah and Parish, 2010, Callard and Hodgkin, 2007, Dalgaard et al., 2010).

For suppression assay experiments, spleens and draining LN cells were collected from IFN- $\alpha$ treated or non-treated mice (control group) at various days of AIA. Single cells suspension of spleen or lymph nodes or combined spleen and LNs were prepared by passing through 70 $\mu \mathrm{m}$ mesh size cells strainer and re-suspended in complete media (Iscove's media, $10 \%$ FCS, 2 \% L-Glutamine, 1 \% Penicillin, 1 \% 2-mercaptoethanol, 1 \% Streptomycin). The cells were stained with rat anti-mouse CD4-FITC (Biolegend, San Diego CA, USA) and rat anti-mouse CD25-PE. The Treg cells (CD4 ${ }^{+} C D 25^{\text {high }}$ ) and responder T cells (Tresp cells, CD $\left.4^{+} C D 25^{-}\right)$were sorted from single cells suspension by FACS-Aria.

Alternatively, Treg cells and Tresp cells were also isolated by a combination of MACS technology and FACS-Aria III. Briefly, CD4 ${ }^{+}$T cells were sorted using MACS (CD4 ${ }^{+}$T Cell Isolation Kit, Miltenyi Biotec, Cologne, Germany). Then, from the sorted CD4+ cells, Tresp cells $\left(C D 4^{+} \mathrm{CD} 25^{-}\right)$and Treg cells $\left(\mathrm{CD} 4^{+} \mathrm{CD} 25^{\text {high }}\right)$ cells were further sorted by FACS Aria using rat anti-mouse CD4-FITC and rat anti-mouse CD25-PE antibodies. 
Sorted Tresp cells were incubated for 5 minutes in dark with CFDA-SE (Sigma Aldrich) at a final concentration of $5 \mu \mathrm{M}$, followed by washing (five times) with buffer (PBS+1 \% FBS). 50,000 CFSE-stained Tresp cells were co-cultured in 96-well round bottom culture plate with decreasing numbers (i.e., $50000,25000,12$ 500, 6250 and 0) of Treg cells. In this way, the ratios of Treg:Tresp will be 1:1, 1:2, 1:4, 1:8 and 0:1 (Tresp cells only). In each well, 100,000 irradiated ( $25 \mathrm{~Gy}$ ) splenocytes from naïve mice were also added for the purpose of antigen presenting cells. Cultures were then stimulated with anti-CD3 $(1 \mu \mathrm{g} / \mathrm{mL})$ or mBSA $(50 \mu \mathrm{g} / \mathrm{mL})$ and cultured for 72 hours. After the culture, the cells were harvested and analysed by FACSGallios to determine the proliferation of CFSE-stained Tresp cells (Fig. 3). Briefly, the live lymphocytes gate was selected based on forward and side scatter. From the lymphocyte gate, the CFSE-positive region was determined in FI-1 channel based on non-stained cells in co-culture. The non-proliferated and proliferated regions from the CFSE gate were then determined in a histogram plot with the help of CFSE-stained irradiated APC, which theoretically does not divide. The non-proliferated region was defined as CFSE ${ }^{\text {high }}$ region occupied by CFSE-stained irradiated APC. The proliferated region was defined as CFSE ${ }^{\text {low }}$ region, which is towards the left of CFSE ${ }^{\text {high }}$ region (Fig. 3). The suppression (expressed as percentage) was calculated based on number of events in the proliferated region (see equation below).
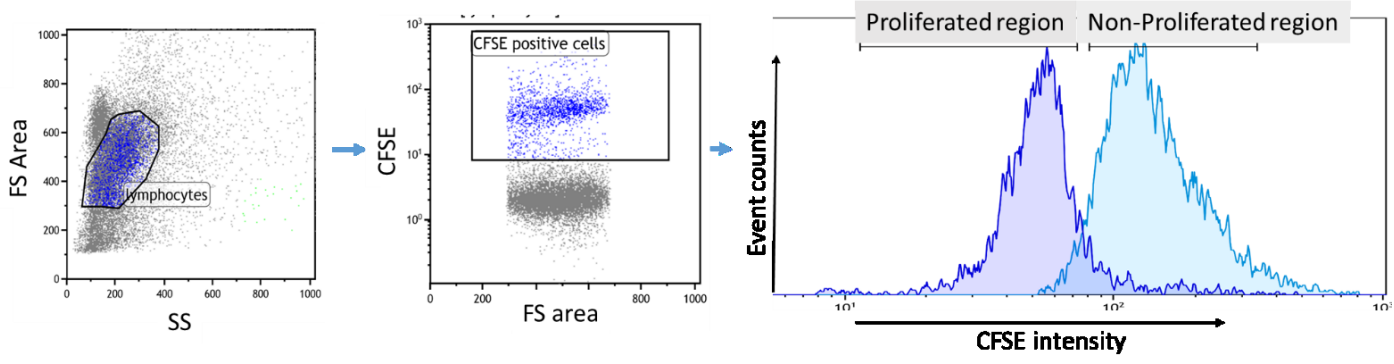

Figure 3. FACS gating strategies applied for calculation of suppression by Treg cells against CFSE-stained Tresp cells.

Suppression $(\%)=1-\frac{\text { Tresp proliferation with Treg cells }}{\text { Tresp proliferation without Treg cells }}$

\section{Tryptophan and Kynurenine determination (Paper III)}

The level of Tryptophan (Trp) and Kynurenine (Kyn) can be determined by several methods. We have tried Mass spectroscopy, Ehrlich's reagent method, Fluorescence method and HPLC method to determine the serum levels of Trp and Kyn. Out of these methods, HPLC method appeared to be efficient and effective, hence all the samples were analysed by HPLC method (data not shown). Standards of Trp and Kyn solution from $0.5 \mu \mathrm{M}$ to $50 \mu \mathrm{M}$ were prepared in albumin solution. $100 \mu$ of methanol:acetyl nitrile consisting of the internal standard methylguanosine was mixed with $50 \mu$ l of serum sample or standards. Thereafter, the samples were vortexed and centrifuged at $10000 \mathrm{rpm}$ for $10 \mathrm{~min}$. Before injection, the 
samples were diluted 5 times with $10 \mathrm{mM}$ acetic acid. $10 \mu \mathrm{l}$ of diluted samples were injected into the HPLC system that uses Waters 2695 separation module equipped with a Waters 2475 multi-wavelength fluorescence detector, controlled by Empower software. Isocratic separation on a XBridge C18 3,5 $\mu \mathrm{m} 3,0 * 150 \mathrm{~mm}$ column with a Gemini C18 4*2,0 security guard cartridge, hold at $30{ }^{\circ} \mathrm{C}$, were used to separate Trp, Kyn and the internal standard methylguanosine, with a mobile phase consisting of 4:96 acetonitrile: $10 \mathrm{mM}$ acetic acid at a flowrate of $0,5 \mathrm{ml} / \mathrm{min}$. The substances were monitored by programmed wavelength detection setting, Kyn excitation at $365 \mathrm{~nm}$ and emission $480 \mathrm{~nm}$, Trp excitation at $300 \mathrm{~nm}$ and emission $350 \mathrm{~nm}$ and internal standard excitation at $310 \mathrm{~nm}$ and emission $390 \mathrm{~nm}$.

\section{In vivo depletion of regulatory T cells (Paper IV)}

Foxp3DTReGFP mice also called DEREG mice (Depletion of Regulatory T cells) were utilized to deplete the Treg cells in vivo. This transgenic mouse strain carries a human diphtheria toxin (DT) receptor gene coupled to a green fluorescent protein (GFP)gene, which is controlled by a Foxp3 promoter (Lahl and Sparwasser, 2011). Upon administration of DT, the Foxp $3^{+} \mathrm{T}$ cell population can be depleted after two days for a limited time in vivo without affecting other cell populations (Lahl and Sparwasser, 2011). The confirmation of Treg cells depletion can be done by analysing GFP positive cells in FACS. The Treg cells re-populate to the original amount in about 7-10 days (Lahl and Sparwasser, 2011). The recommended dose of DT to deplete Foxp3 cells is $1 \mathrm{mg}$ daily for three consecutive days (Lahl and Sparwasser, 2011) however after several optimization experiments, we found that a single dose i.p. injection of $250 \mu \mathrm{g}$ DT in $100 \mu \mathrm{l}$ PBS can deplete up to 90 percent of Foxp3 ${ }^{+}$T cells 2 days after the DT injection in blood (Fig.4) and in spleens (data not shown). Hence, we used a single dose of $250 \mu \mathrm{g}$ to deplete the Foxp3 T cells. Foxp3 ${ }^{+} \mathrm{T}$ cells were depleted at various time points by injecting DT at day 0, 5 and 19 of AIA.
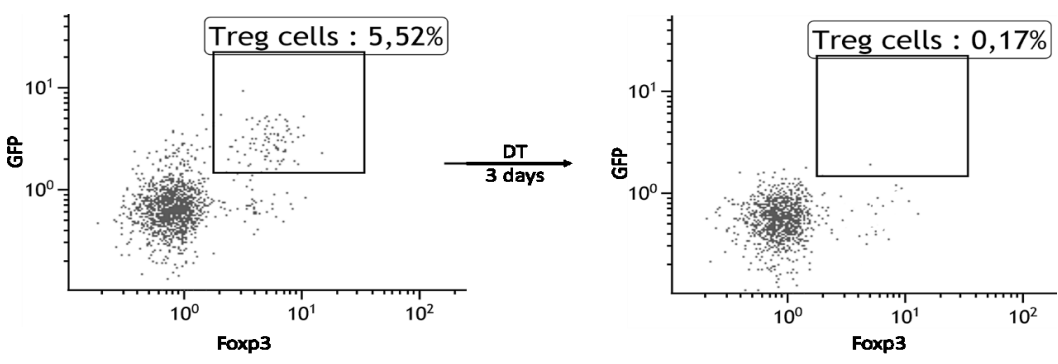

Figure 4. In vivo depletion of Treg cells in DEREG mice. DT $(250 \mu \mathrm{g})$ was injected i.p. in Foxp3DTReGFP mice. FACS analysis was performed for the quantification of $\mathrm{GFP}^{+}$Foxp3 ${ }^{+}$cells before and after three days of DT injection. Representative FACS dot plots showing percentage of GFP ${ }^{+}$Foxp $3^{+}$cells in blood of DEREG mice before (left), and after three days (right). 


\section{Adoptive transfer of regulatory T cells (Paper IV)}

Spleens and draining lymph nodes (axillary, popliteal, inguinal) were collected at day 20 of AIA from IFN- $\alpha$ treated or non-treated mice. $C D 4^{+} C D 25^{\text {high }}$ Treg cells were isolated from combined splenocytes and LN cells by FACS ARIA as described above for CFSE-based suppression assay. The sorted cells were washed and suspended with PBS. 50,000-250,000 T reg cells were intravenously injected in the tail vein of mice at day 20 of AIA induced without IFN- $\alpha$. For $i . v$ injection of Treg cells, the tail was warmed under a heating lamp until the vein became clearly visible. Then Treg cells were injected in 50-100 $\mu$ PBS using an insulin syringe. The next day (day 21), arthritis was induced in recipient mice by intra-articular injection of mBSA. The mice were sacrificed at day 28 and arthritis severity was evaluated as described above. 


\section{RESULTS AND DISCUSSION}

Note: This section describes and discusses the major findings in papers I, II, III and IV in a concise form. Please go to the specific papers for full details regarding results and discussion.

\section{IFN- $\alpha$ protects against antigen induced arthritis (Paper I and II)}

As mentioned in the introduction, previous studies from our lab showed that dsRNA, a potent inducer of type I IFN, induces arthritis in a type I IFN dependent manner when injected into a healthy mice joint (Magnusson et al., 2006). This arthritogenic property of dsRNA was further supported by subsequent studies showing that dsRNA can induce murine arthritis after type I IFN signalling in DCs (Narendra et al., 2014). It has previously been demonstrated that dsRNA is also present in synovial fluid of patients with erosive RA (Bokarewa et al., 2008). The arthritogenic effect of dsRNA in mice was established in 3 days after intra-articular injection. Thereafter, the arthritis subsided within a few days. The observed dsRNA induced arthritis is likely to depend on activation of the innate immune system, since dsRNA can also induce arthritis in severe combined immuno-deficient (SCID) mice which are devoid of functional T and B cells (Zare et al., 2004).

RA is an autoimmune disease where both innate and adaptive immunity is involved (discussed in introduction). The main aim of paper I was to investigate the role of dsRNA for arthritis development in an animal model resembling this feature of RA. To this end, we used the mBSA-induced arthritis model (AIA) where mice were immunized with mBSA in the presence of adjuvant at day 1 , followed by booster sensitisation at day 7 . Arthritis was then induced in the sensitized mice at day 21 by intra-articular injection of mBSA in a knee joint. Arthritis was evaluated at day 28 (see Methods). Thus, the 28 days period of AIA was divided into two parts; i.e., the sensitisation/immunisation phase before induction of arthritis (day 120) and the arthritis/effector phase (day 21-28) (Fig. 1).

To study the effect of dsRNA during AIA, dsRNA was mixed with the immunising emulsion containing mBSA and adjuvant (see Methods). In contrast to the previously observed acute arthritogenic effect of dsRNA, dsRNA given at the time of sensitisation (day 1 and 7 of AIA) protected against arthritis in the AIA model. (Paper I, Fig.1). This protection was dependent on type I IFN signalling since mice lacking the receptor for type I IFN (IFNARKO mice) were not protected by dsRNA treatment (Paper I, Fig.1). We next asked if IFN- $\alpha$, a major cytokine induced by dsRNA, can protect against AIA. We replaced the dsRNA with $1000 \mathrm{U}$ of IFN- $\alpha$ and induced AIA as described above. Also with IFN- $\alpha$ given in the sensitisation phase, the development of arthritis was clearly prevented (Fig.5). However, the same dose of IFN- $\alpha$ $(1000 \mathrm{U})$ when administrated during the effector phase of AIA (day 21), did not protect against arthritis (Paper I, described in result section). This indicates that IFN- $\alpha$ should be present during the mBSA sensitisation to confer protection. When mBSA-immunity was already established i.e., at the time of arthritis induction, $1000 \mathrm{U}$ of IFN- $\alpha$ was not able to 
affect the severity of arthritis. In contrast, repeated systemic administrations of dsRNA or type I IFNs during the effector phase in antibody-mediated models of arthritis, which mainly depends on innate immunity in the recipient, shows an ameliorating effect (Yarilina et al., 2007, Corr et al., 2009). Thus, depending on the dose and timing, type I IFN may exert antiarthritic effects through multiple mechanisms.

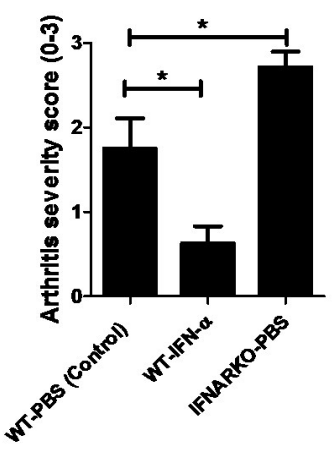

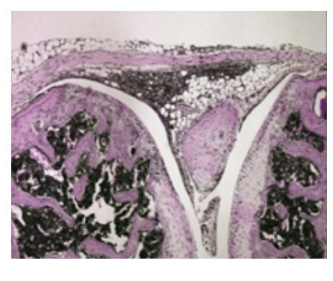

WT-PBS (Control)

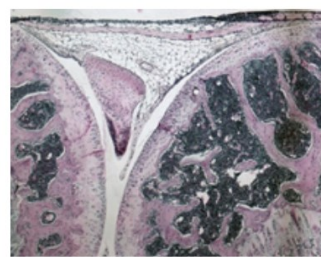

WT-IFN- $\alpha(1000 U)$

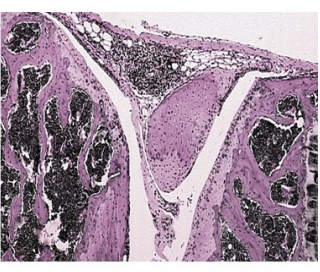

IFNARKO-PBS

Figure 5. Effect of IFN- $\alpha$ in mBSA-induced arthritis. Arthritis was induced in the presence or absence of IFN- $\alpha$ in WT mice, and in IFNARKO mice as described in methods. The bar graph shows the severity score of arthritis evaluated at day 28 of AIA. Comparison of arthritis severity score between different treatment groups was done by Mann Whitney $U$ test $(* p<0.05$ ). The images (magnification $40 X$ ) are the representative joint sections from each group.

Like dsRNA, IFN- $\alpha$ mediated protection against AIA was dependent on type I IFN signalling as IFNARKO mice were not protected (Fig. 5). In fact, the IFNARKO mice developed more severe arthritis than wild type (WT) mice without IFN- $\alpha$ treatment (Fig. 5), which may indicate an endogenous limiting effect on arthritis by type I IFN signalling. The ameliorating effect of type I IFN-signalling against arthritis is also reported in NADPH-mediated suppression of pristane-induced arthritis in rats, and collagen induced arthritis in mice (Olofsson et al., 2007, Treschow et al., 2005).

We next determined the minimal dose of IFN- $\alpha$ required to protect against AIA in three commonly used mouse strains; Balb C, C57bl/6, and SV129. Inclusion of $1000 \mathrm{U}$ IFN- $\alpha$ at sensitisations protected approximately 80,75 and 58 percent respectively in SV129, C57bl/6 and Balb C mice (the percentages regarding SV129 and C57bl/6 strains were based on the medians from several experiments presented in papers I-IV). $5000 \mathrm{U}$ IFN- $\alpha$ could protect more than 90 percent of SV129 and around 70 percent of Balb C mice (Paper II, Fig.1). $100 \mathrm{U}$ of IFN- $\alpha$ could not protect more than 40 percent of mice in any strain (Paper II, Fig.1), hence we used $1000 \mathrm{U}$ of IFN- $\alpha$ for further experiments in paper III and IV. The dose- and straindependent differences regarding the anti-arthritic effect of IFN- $\alpha$ might be the result of variable homeostasis of IFN- $\alpha$ signalling in different mice. SV129 is reported to have higher endogenous IFN- $\alpha$ production than many other strains (Asselin-Paturel et al., 2003), which might explain the better protective effect of IFN- $\alpha$ in SV129 mice compared to Balb C and c57bl/6 


\section{Effect of IFN- $\alpha$ on the humoral response during AIA: IFN- $\alpha$ has limited effect on humoral response (Paper I and II)}

The mBSA induced arthritis model involves generation of mBSA-specific antibodies, which have the capacity to transfer disease to non-immunized mice (Brackertz et al., 1977). Type I IFN is known to regulate humoral responses, including promotion of class switch (Le Bon et al., 2001). To investigate if the mechanism behind IFN- $\alpha$-protection involves alteration of the anti-mBSA humoral response, we determined the level of mBSA-specific antibodies in serum samples collected from IFN- $\alpha$-treated and non-treated WT mice and IFNARKO mice at day 0 , 13,20 , and at day 28 of AIA. We observed time-dependent increases of mBSA-specific total IgG levels (maximum at the time of arthritis manifestation) in sera from IFN- $\alpha$-treated as well as non-treated mice. However, there were no significant differences between the groups, although IFN- $\alpha$-treated mice were clearly protected (Paper I, Fig. 4).

Murine IgG consists of the IgG1, IgG2a, IgG2b subclasses, which by themselves exhibit different physiological roles (Bruhns, 2012). It has been reported that amelioration of AIA by NF-kappa B-deficient DCs involves the modulation of anti-mBSA antibody repertoire from IgG2a and 2b to IgG1 and IgA (Martin et al., 2007). Therefore, we also screened for mBSAspecific IgG1, IgG2a, IgG2b separately at the same days as for total IgG. However, we did not observe any significant differences in IgG subtypes between IFN- $\alpha$ treated and non-treated groups (Paper II, Fig. 2). IgA and IgE also represent important parts of humoral immunity. In fact, these immunoglobulins are reported to have anti-inflammatory properties under certain conditions including RA (Russell et al., 1997, Svard et al., 2012, Thompson et al., 2008, Ekerfelt et al., 2007). We therefore also investigated the serum levels of mBSA-specific $\operatorname{IgA}$ and IgE during AIA. However, we did not observe any significant differences in those antibodies in mice treated or not treated with IFN- $\alpha$ (Paper II, Fig. 2).

These observations suggest that the mechanism behind IFN- $\alpha$-protection against AIA does not involve modulation of the antibody response and also question the pathogenic role of antibodies in mBSA-induced arthritis. In fact, it was observed that mice deficient of mature $B$ cells, and thus unable to secrete antibodies, also are susceptible to mBSA-induced arthritis to mBSA-induced arthritis induced arthritis (Notley et al., 2011, Wong et al., 2006). 


\section{Effect of IFN- $\alpha$ on T cells during AIA: IFN- $\alpha$ inhibits antigen-specific leucocyte proliferation ex vivo (Paper I and IV)}

In AIA, upon intra-articular injection of $\mathrm{mBSA}$, arthritis develops in pre-sensitized mice as a result of activation of mBSA-specific T cells (Brackertz et al., 1977). To investigate if IFN- $\alpha$ modulates $T$ cells during the development of arthritis, we studied the mBSA-specific ex vivo proliferative response of leucocytes at different days of AIA. For this purpose, we isolated splenocytes and LN cells at day $0,13,20$ and 28 of AIA from WT mice treated with or without IFN- $\alpha$ and re-stimulated ex vivo for 72 hours with $50 \mu \mathrm{g} / \mathrm{ml}$ of mBSA or ConA $1 \mu \mathrm{g} / \mathrm{ml}$ (positive control) or media (mock) (see Methods). Proliferation of cells was then determined as described in the Methods section. In WT control mice, the proliferation of splenocytes and LN cells increased significantly at day 13 compared to day 0 , but this increase of proliferation was clearly inhibited by IFN- $\alpha$ treatment (Fig. 6). At day 21 , no difference in proliferation was observed between groups. After the intra-articular injection of mBSA at day 21 , a recall response was observed in control WT mice at day 28 which is characterized by significant higher proliferation of LN cells than on day 21 (Fig. 6). Interestingly, IFN- $\alpha$ (given only at day 1 and 7) impaired this re-call response observed three weeks after the second sensitisation (Fig. 6) This long-term inhibitory effect of IFN- $\alpha$ on proliferative response is antigen-specific as no differences were observed between groups in ConAstimulated or mock-stimulated splenocytes and LN cells at any time point of AIA (data not shown).
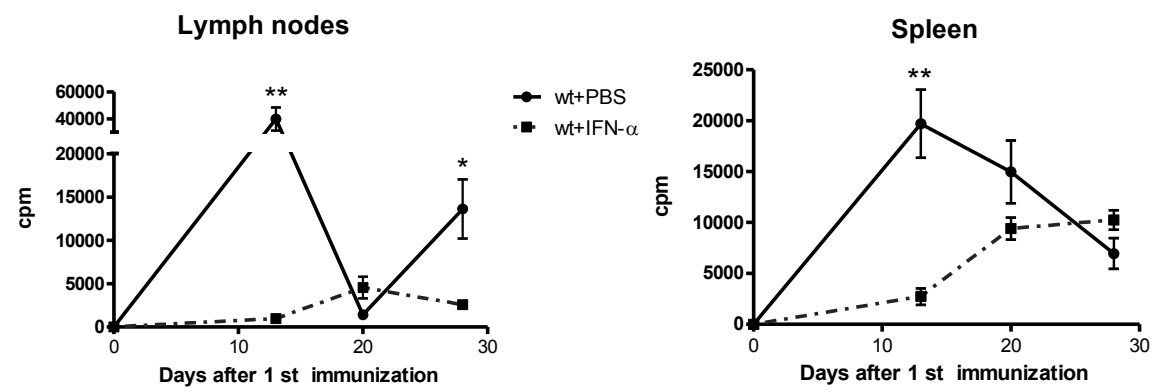

Figure 6. Effect of IFN- $\alpha$ on mBSA-induced proliferation ex vivo. At days $0,13,20$ and 28 of AIA, total lymph nodes and spleen cells from WT and WT mice immunized in the presence of IFN- $\alpha$ were isolated and restimulated with medium or $50 \mu \mathrm{g} / \mathrm{mL}$ mBSA. After $60 \mathrm{~h}$ incubation, in the presence of tritiated thymidine during the last $12 \mathrm{~h}$, proliferation (cpm) was assessed in a Beta-counter. The cpm-value from mock-stimulation (medium) for each individual has been subtracted. Values are expressed as cpm \pm SEM, $n \geq 5 .{ }^{*} p<0.05$, WT ** $p<0.01$ (Mann Whitney U test).

These data show that the IFN- $\alpha$-protection of arthritis is accompanied by inhibition of antigen-specific proliferation of leucocytes. This indicates the involvement of T cells in the protective mechanism by IFN- $\alpha$. In theory, IFN- $\alpha$ could act directly on T cells or indirectly 
modulate T cells responses through other cells. We asked if the protective effect of IFN- $\alpha$ is the result of direct effect of IFN- $\alpha$ on T cells. To this end, in paper IV, we investigated the IFN- $\alpha$-protective effect in AIA in CD4-Cre+/- IFNAR f/fl mice where the IFN- $\alpha$ receptor (type I IFN receptor) was knocked out exclusively on $C D 4^{+} \mathrm{T}$ cells. When treated with IFN- $\alpha$, mice lacking type I IFN receptor on $\mathrm{CD}^{+}{ }^{+} \mathrm{T}$ cells were equally protected against AIA compared to their wild type counterparts (Fig. 7). This indicates that IFN- $\alpha$ acts on other cell populations than $\mathrm{CD} 4{ }^{+}$cells for the protective effect and that $\mathrm{CD} 4^{+} \mathrm{T}$ cells are only indirectly affected (see also Paper IV) during IFN- $\alpha$ protection against arthritis. Further studies are needed to know if IFN- $\alpha$ signalling on T cells are required for IFN- $\alpha$-mediated inhibitory effects on leucocytes proliferation ex vivo.

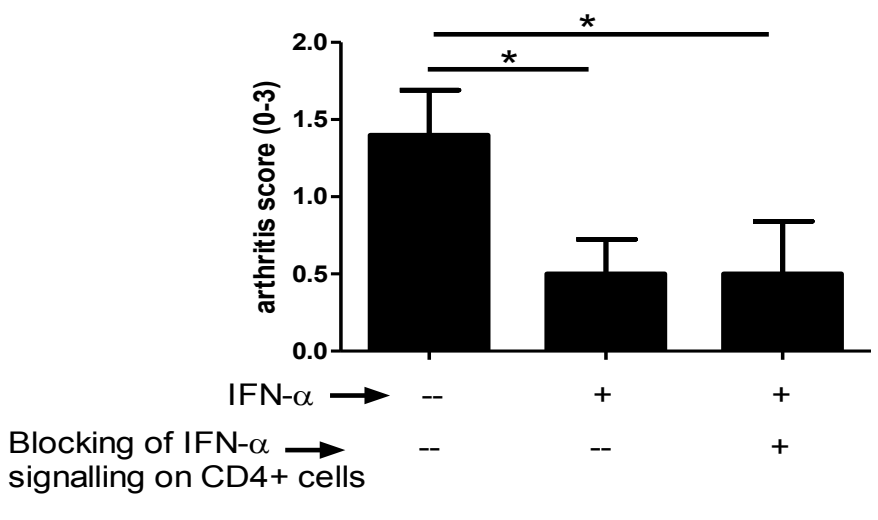

Figure 7. Type I IFN signalling in T helper cells is not required for IFN- $\alpha$-protection against AIA. AIA was induced in female CD4-Cre ${ }^{+-}$IFNAR ${ }^{\text {fl/fl }}$ mice or their wild type littermates CD4-Cre ${ }^{-/}$IFNAR ${ }^{\text {flffl }}$ mice with or without $1000 \mathrm{U}$ IFN- $\alpha$ as described in methods. The level of arthritis evaluated at day 28 of AIA is expressed as severity score (mean $\pm S E M, n \geq 7$ ). Comparison of arthritis severity score between different IFN- $\alpha$ treated and non-treated groups was done by the Mann Whitney $U$ test $(* p<0.05)$.

\section{Effect of IFN- $\alpha$ on cytokine production during AIA: IFN- $\alpha$ inhibits pro-inflammatory cytokines but increases TGF- $\beta$ during AIA (Paper II)}

Cytokines are important in the pathogenesis of RA and experimental models thereof (discussed in introduction). In paper II, we have performed a descriptive, hypothesisgenerating study on how IFN- $\alpha$ affects the pro-inflammatory and immune-modulatory/antiinflammatory cytokines during the development of anti-mBSA immunity and arthritis.

First, we determined the level of pro-inflammatory cytokines (IL-1 $\beta$, IL-6, IL-17, IL-12, TNF) and immune-modulatory cytokines (IFN- $\gamma$, TGF- $\beta$ and IL-10) in serum samples collected at day $0,14,21,28$ of AIA from mice treated or untreated (control) with IFN- $\alpha$ (1000 U and $5000 \mathrm{U})$. In control mice, the cytokines were significantly elevated at day 14 compared to 
day 0 . Thereafter, the levels of IL-6, IL-17, TNF diminished at day 21 whereas IL-1 $\beta$ and IFN- $\gamma$ remained unchanged between day 14 and day 21 (Fig. 8). At day 28, one week after intraarticular injection of mBSA, the levels of IL-1 $\beta$, IL-6, IL-12, IL-17, IFN- $\gamma$ and TNF were increased significantly compared to day 21 , whereas TGF- $\beta$ levels diminished to baseline (Fig. 8). This systemic re-increase of cytokines (IL- $\beta$, IL-6, IL-12, IL-17, IFN- $\gamma$ and TNF) and decrease of TGF- $\beta$ at day 28 was clearly due to the effect of intra-articular injection as the cytokines levels decreased or remained constant at day 28 in pre-immunized mice that did not receive intra-articular injection (Fig. 8, dotted lines). Earlier studies have also reported the systemic induction of pro-inflammatory cytokines IL-1 $\beta$, IL- 6 and TNF in serum and increased mRNA expression of IL-1 $\beta$, IL-6, and IFN- $\gamma$ in lymphoid tissues as a result of locally induced arthritis (Simon et al., 2001, Pohlers et al., 2005).

Administration of IFN- $\alpha$ at day 1 and 7 altered the described cytokine profile observed in control mice in a dose-dependent manner. At day 14, $5000 \mathrm{U}$ of IFN- $\alpha$ decreased the levels of IL-12, IL-6, TNF and IL-10. Similarly, $1000 \mathrm{U}$ of IFN- $\alpha$ decreased significantly IL-6, IL-10, and to some extent IL-12 and TNF (Fig. 8, blue and red lines). Interestingly, at day 28 , IFN- $\alpha$ administration at day 1 and 7 prevented the reactivation of cytokine production observed in control mice. The levels of all cytokines at day 28 were significantly lowered by $5000 \mathrm{U}$ IFN- $\alpha$. Similarly, but to a lesser extent than $5000 \mathrm{U}$, the cytokines IL-1 3 , IL-12, IL-17, IFN- $\gamma$, and TNF decreased in mice treated with $1000 \mathrm{U}$ IFN- $\alpha$ (Fig. 8). In contrast to these cytokines, the effect of IFN- $\alpha$-treatment was opposite for TGF- $\beta$. At day 14 and day 28 , serum levels of TGF$\beta$ were clearly higher in mice treated with 1000 and $5000 \mathrm{U}$ of IFN- $\alpha$ than the control group (Fig. 8).

Taken together, during AIA, IFN- $\alpha$ inhibits the increase in pro-inflammatory cytokines twice: first in the sensitisation phase and then during the manifestation of arthritis, while at the same time it induces TGF- $\beta$ production in the sensitisation phase and prevents its decrease in the arthritis phase.

We have also measured the above-mentioned cytokines in the supernatants of ex vivo mBSA-stimulated splenocytes and LN cells collected at the same days as for serum analysis (see methods). The inhibitory effect of in vivo administration of IFN- $\alpha$ on pro-inflammatory cytokine production was clearly apparent at day 14 for both spleen and LNs (Paper II, Fig.6). However, at day 28 , the supernatant of spleen cell cultures from IFN- $\alpha$-treated mice showed significantly higher levels of cytokines than the control mice (Paper II, Fig. 6). This observation is in sharp contrast with the in vivo situation, where the inhibitory effect of IFN$\alpha$ on pro-inflammatory cytokines in serum was still present at day 28 (Fig. 8). Considering these two contradictory effects of IFN- $\alpha$ on cytokine production by splenocytes ex vivo, i.e., inhibition at day 14 and enhancement at day 28 , it can be inferred that the IFN- $\alpha$-effect may have a time limit and may be reversible. However, the enhancing effect of IFN- $\alpha$ on TGF- $\beta$ production in vivo was clearly apparent also ex vivo at both day 14 and day 28. (Fig. 9). 
PBS $\quad-$ IFNa $1000 \mathrm{U}=$ IFNa $5000 \mathrm{U} \quad$ - Without Intra articular Inj.

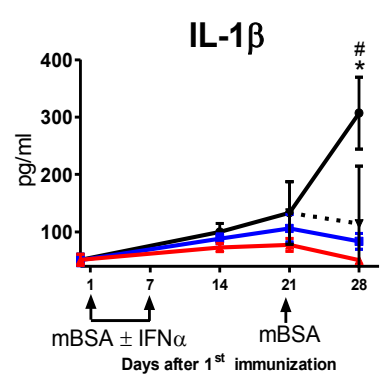

IL-17

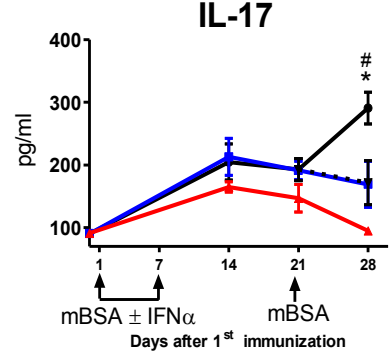

IL-10

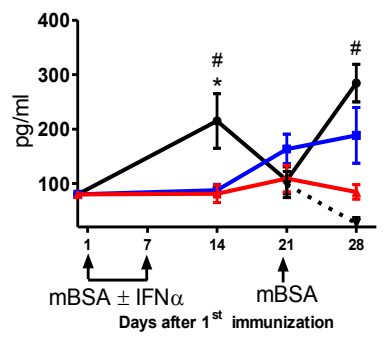

IL-6

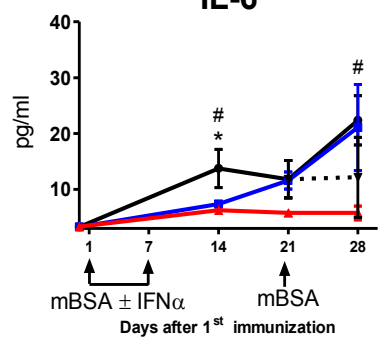

IFN- $\gamma$

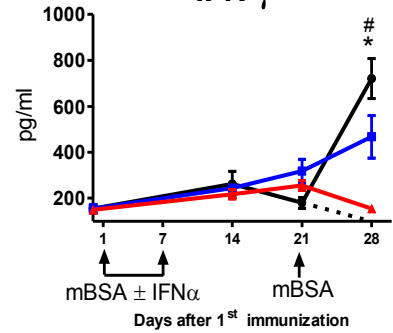

IL-13

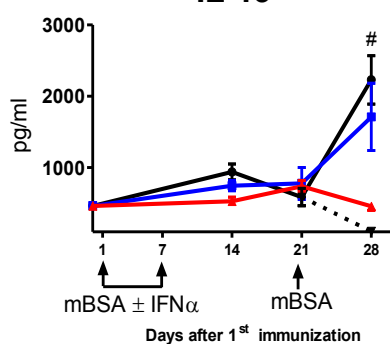

IL-12

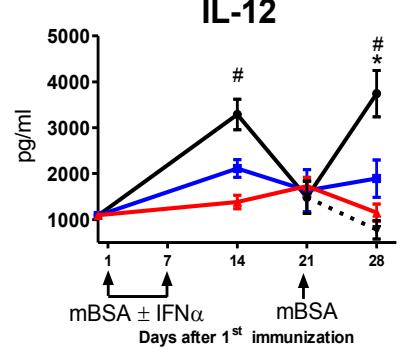

TNF

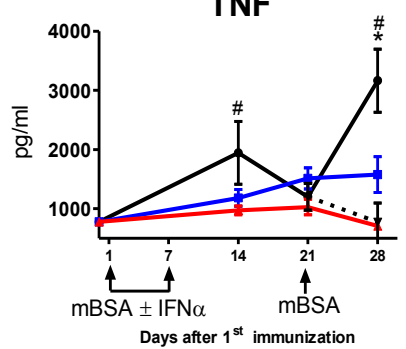

TGF- $\beta$

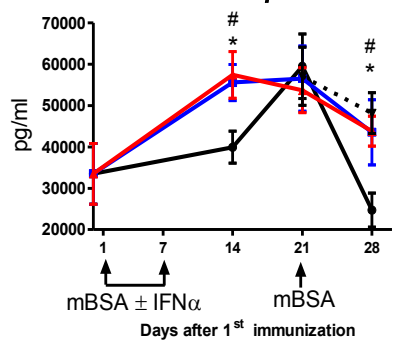

Figure 8. IFN- $\alpha$ down modulates initial activation and subsequent antigen induced reactivation of proinflammatory cytokines but enhances the initial activation and prevents subsequent antigen induced inhibition of TGF- $\beta$ reactivation. Mice were immunized twice with mBSA plus IFA with or without $1000 \mathrm{U}$ IFN- $\alpha$ in one week interval followed by intra-articular injection of mBSA in PBS 21 days later. Levels of IL-1- $\beta$, IL-6, IL12 , IL-17, TNF, IFN- $\gamma$, IL-10 and IL-13 were determined by Luminex, and TGF- $\beta$ by ELISA in serum collected at day 0 , day 14, day 21 and 28 during the course of AIA. Data are expressed as mean pg/ml \pm SEM $(n \geq 6)$. The black line, blue line and red line represent groups receiving $0 \mathrm{U}, 1000 \mathrm{U}$ and $5000 \mathrm{U}$ of IFN- $\alpha$, respectively at the time of $\mathrm{mBSA}$ sensitisations. Mann Whitney $\mathrm{U}$ test was performed to compare cytokine level between two groups. Animals not receiving intra-articular injection of mBSA (the dotted line) produced significantly $(p<0.05)$ less of all analysed cytokines at day 28 compared to the control group. ${ }^{*} p<0.05$ between PBS (black) and IFN- $\alpha 1000 \mathrm{U}$ (blue). \# $p<0.05$ between PBS (black) and IFN- $\alpha 5000 \mathrm{U}$ (red). The experiment was performed twice with similar results. 

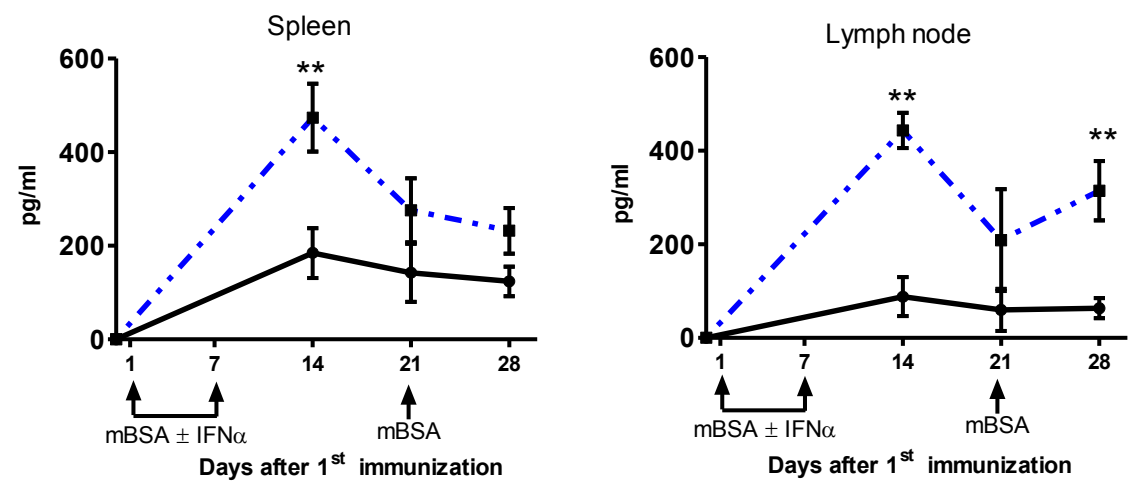

Figure 9. IFN- $\alpha$ enhances TGF- $\beta$ production from splenocytes and lymph node cells ex vivo. Spleens and draining lymph nodes were collected from mice at day 0, 14, 21 and 28 during the course of AIA. Single cell suspensions were prepared and were re-stimulated with $50 \mu \mathrm{g} / \mathrm{ml}$ of mBSA for $48 \mathrm{hrs}$. The supernatant of the culture was analysed for TGF- $\beta$ by ELISA. The data are expressed as mean $\mathrm{pg} / \mathrm{ml} \pm \operatorname{SEM}(n \geq 6)$ in splenocytes (left) and lymph nodes cells (right). From each value, the background cytokine levels found in culture media (including fetal bovine serum) were subtracted. The black line and the blue dotted line represent groups receiving $0 U$ and $1000 U$ of IFN- $\alpha$ respectively at the time of mBSA sensitisations. Mann Whitney $U$ test was performed to compare cytokine levels between the two groups $(* * p<0.01)$.

To determine the cells involved in IFN- $\alpha$ mediated decrease in IL-17 and IFN- $\gamma$ and increase in TGF- $\beta$, we measured intracellular IL-17, IFN- $\gamma$ and TGF- $\beta$ within T cells (CD4 ${ }^{+}$) and M Ms (F4/80 cells) by FACS in the re-stimulated leucocytes isolated at $0,14,21$ and 28 of AIA (see methods for details). In the re-stimulated LN cells isolated from IFN- $\alpha$-treated mice, IFN- $\nu$ was inhibited in both $\mathrm{CD} 4^{+} \mathrm{T}$ cells and M $\phi$ s whereas IL-17 production was inhibited only in CD4 ${ }^{+} \mathrm{T}$ cells (Fig. 10). These observed IFN- $\alpha$-modulation of cytokines is clearly antigen specific as IFN- $\alpha$ had no inhibiting effect on the number of IFN- $\gamma$ and IL-17 producing cells when lymph node and spleen cells were unstimulated (mock) or generally stimulated by anti-CD3 (Paper II Supplementary Fig. 2 and 3). In contrast to IFN- $\gamma$ and IL-17, presence of IFN- $\alpha$ at sensitisations clearly augmented the number of TGF- $\beta$ producing $F 4 / 80^{+} M \phi s$ and $\mathrm{CD}^{+} \mathrm{T}$ cells, as depicted on day 14 and 21 of AIA in M $\phi$ of lymph node cells and day 21 in $\mathrm{CD}^{+} \mathrm{T}$ cells of splenocytes (Fig. 8). Taken together, IFN- $\alpha$ decreased the expression of IFN- $\gamma$ and IL-17 in T cells while increasing the TGF- $\beta$ expression first in M申s (day 14 and 21, LNs) and then in T cells (day 21, spleen). 
A
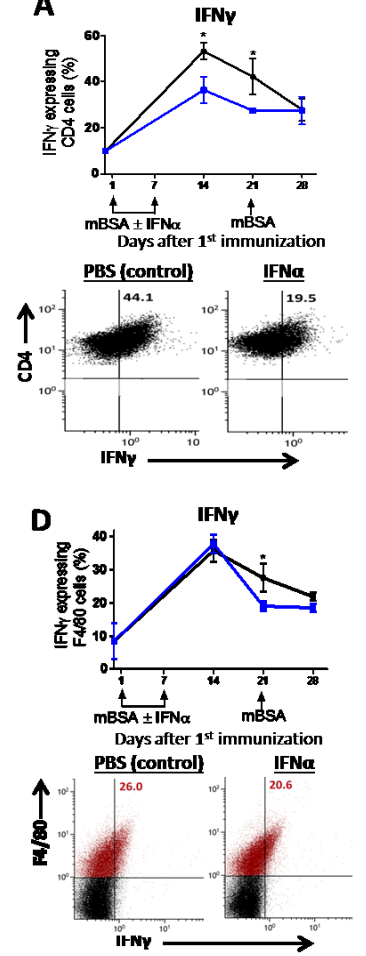
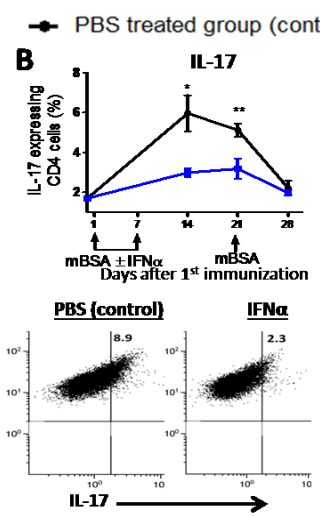

E

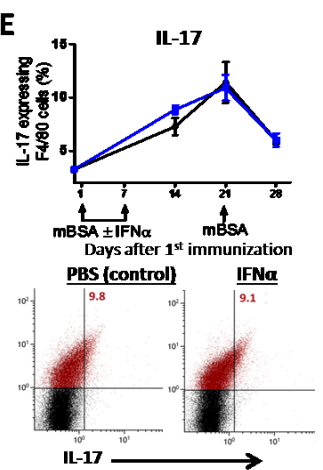

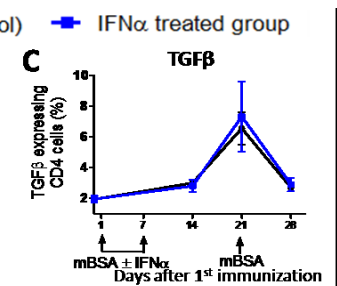

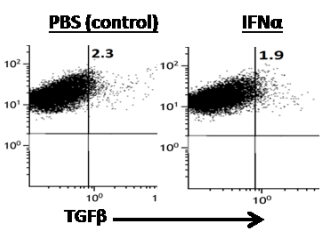

$\mathbf{F}$

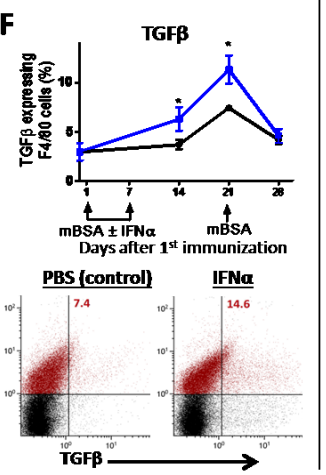

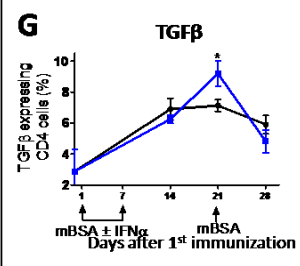

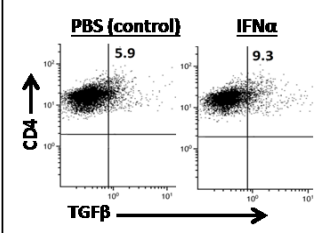

H

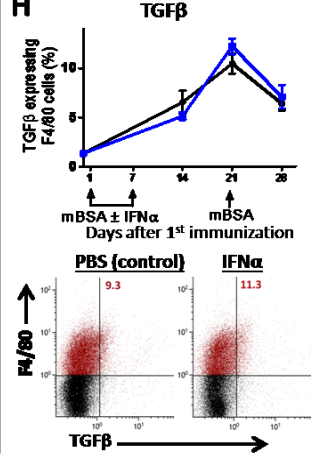

Figure 10. IFN- $\alpha$ regulates TGF- $\beta$ and IFN- $\gamma$ production in M\$s and TGF- $\beta$, IL-17 and IFN- $\gamma$ production in Tcells. Draining lymph nodes and spleen cells were collected from mice at day $0,14,21$ and 28 during the course of AIA and re-stimulated with mBSA (50 $\mu \mathrm{g} / \mathrm{ml})$ for $24 \mathrm{hrs}$. Brefeldin A $(5 \mu \mathrm{g} / \mathrm{ml})$ and monensin $(1 \mathrm{ug} / \mathrm{ml})$ were added 5 hrs before FACS analysis. A-F) Percentage IFN- - , IL-17A and TGF- $\beta$ expressing lymph node cells of CD4 ${ }^{+}$

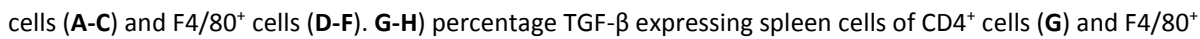
cells $(H)$ during the course of AIA. Below each graph is a representative dot plot of the same cells from mice with or without IFN- $\alpha$ treatment during AIA at day 14 (A-C) and day 21 (D-H). For CD4 ${ }^{+}$cells, only gated cells are depicted. $\mathrm{F} 4 / 80^{+}$gated cells are depicted in red and the figure in the upper right quadrant represents the percentage of cytokine producing cells among $F 4 / 80$ (red) cells. The data shown are mean values \pm SEM of pooled data from two independent experiments $(n \geq 5)$ with similar results. ${ }^{*} P<0.05,{ }^{*} P<0.01$. Blue line: mice immunized in the presence of IFN- $\alpha$, Black line: control.

In conclusion, in paper II we showed that IFN- $\alpha$-protection against AIA was accompanied with the inhibition of pro-inflammatory cytokines and the induction of immune-regulatory TGF- $\beta$. TGF- $\beta$ induces immune tolerance by enhancing Treg cells, however, in the presence of IL-6, TGF- $\beta$ can inhibit Treg cells development while promoting the generation of Th17cells (Bettelli et al., 2006, Zhou et al., 2008, Kimura and Kishimoto, 2010). During the sensitisation phase of AIA, while TGF- $\beta$ levels were significantly higher, the levels of IL- 6 in IFN- $\alpha$-treated mice were significantly lower than in the control group (Fig. 8). Therefore, by initially activating TGF- $\beta$ but downregulating pro-inflammatory cytokines including IL-6, IFN- 
$\alpha$ may favour TGF- $\beta$-dependent tolerance while preventing the possible activation of TGF$\beta+I L-6$ induced Th17 differentiation.

\section{The protective effect of IFN- $\alpha$ in AIA is mediated by TGF- $\beta 1$ (Paper}

\section{III)}

The observed increase in TGF- $\beta$ production (paper II), both in the sensitisation phase and during the arthritis phase emphasizes the importance of TGF- $\beta$ during IFN- $\alpha$-protection against AIA. To determine if the IFN- $\alpha$-protection could be mediated by TGF- $\beta$, the cytokine was neutralized using a specific neutralizing Ab during the sensitisation phase (day 1-9) or the arthritis phase (day 21-28) of AIA. The IFN- $\alpha$-protection was clearly abrogated when TGF$\beta$ signalling was blocked in the sensitisation phase (Fig. 11, A) but IFN- $\alpha$ was still able to protect against arthritis when TGF- $\beta$ was blocked in the arthritis phase of AIA (Fig. 11, A). Therefore, for IFN- $\alpha$-protection against AIA, TGF- $\beta$ appears to be indispensable in the sensitisation phase but not in the arthritis phase.

A

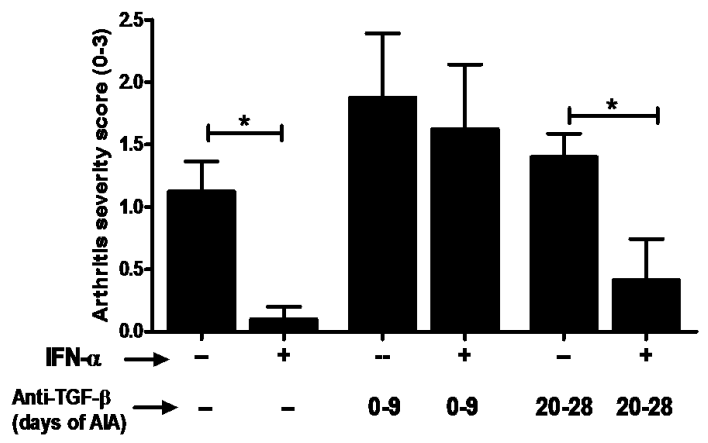

B

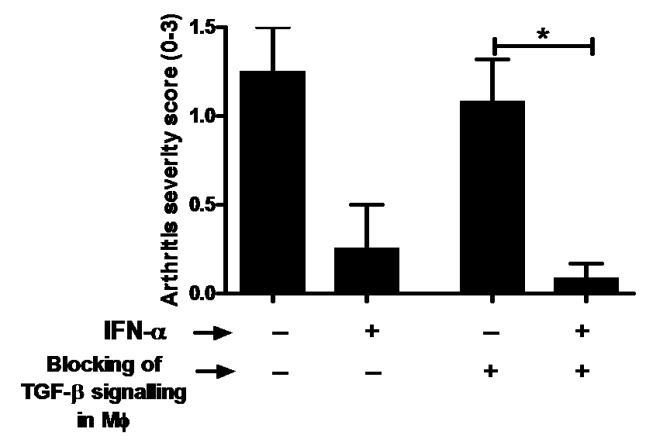

Figure 11. The protective effect of IFN- $\alpha$ against AIA is mediated by TGF- $\beta$ signalling in the sensitisation phase. AIA was induced in WT Sv129 mice and LysM Cre ${ }^{+/-} T g f b r 2^{f / f f}$ with or without IFN- $\alpha$ treatment. TGF- $\beta$ signalling was blocked in WT mice by daily i.p injection of $150 \mu \mathrm{g}$ anti-TGF- $\beta$ antibody for the first 0-9 or 20-28 days of AIA. (A) The level of arthritis expressed as severity score (mean $\pm S E M, n \geq 4$ ) from WT mice with or without IFN- $\alpha$ and anti-TGF- $\beta$ treatment. (B) The level of arthritis expressed as severity score (mean \pm SEM, $n \geq 6$ ) from LysM Cre ${ }^{+/-} T g f b r 2^{f / f l}$ mice with or without IFN- $\alpha$ treatment. Comparison of arthritis severity score between different groups was done by Mann Whitney $U$ test $(* P<0.05)$.

M $\phi$ represent an important source of TGF- $\beta$ (Nacu et al., 2008). We have observed an early increase in expression of TGF- $\beta$ in M $\phi$ in ex vivo re-stimulated leucocytes from IFN- $\alpha$-treated mice (Fig. 10). Also, TGF- $\beta$ was required in the sensitisation phase for IFN- $\alpha$-protection (Fig. 11). These two observations prompted us to hypothesize that TGF- $\beta$ expression in M $\phi$ are important for IFN- $\alpha$-protection of AIA. To this end, we evaluated the protective effect of 
IFN- $\alpha$ in LysM Cre ${ }^{+}$Tgfb $^{\text {flox/flox }}$ mice that lack the TGF- $\beta$ encoding gene only in M $\phi$. In these mice, IFN- $\alpha$ protected against AIA to the same extent observed in mice with intact TGF- $\beta$ activity in $M \phi$ (Fig. 11, B). Thus, TGF- $\beta$ production by $M \phi$ is not required for protection by IFN- $\alpha$ in AIA. However, as CD4 ${ }^{+}$T cells also contribute to IFN- $\alpha$-induced TGF- $\beta$ production during AIA (Fig. 10, G) and plasmocytoid DCs can produce TGF- $\beta$ (Saas and Perruche, 2012), knocking out one single cellular source may not sufficiently alter the amount of TGF- $\beta$.

\section{Indoleamine 2, 3 dioxygenase and IFN- $\alpha$-protection of AIA (Paper III)}

\section{IDO1 mediates the protective effect of IFN- $\alpha$ in AIA}

IDO1 is a natural immune-regulatory component that contributes to immune-suppression and tolerance in a variety of inflammatory settings (Munn and Mellor, 2013). IDO1 can be induced by IFNs (both type I and II) and TGF- $\beta$ during inflammation (Munn and Mellor, 2013). In paper II, we observed increased level of TGF- $\beta$ in serum and also in the supernatant of ex vivo re-stimulated lymph node cells and splenocytes (Fig. 8 \& 9). In paper III, we therefore, investigated whether IFN- $\alpha$-protection against AIA may be associated with IDO1.

First, we monitored Ido1 transcript expression in spleen and LN cells from mice treated or untreated with IFN- $\alpha$. We found some increase, though not significant in Ido1 expression at day 4 in spleen cells and LN cells from IFN- $\alpha$ treated mice as compared to cell counterparts purified from control mice, with no differences at all other analysed time points (Fig. 12, A). At the cellular level, IDO1 is known to be expressed mainly in antigen presenting cells particularly pDCs (Mellor and Munn, 2004). When analysing Ido1 transcripts in pDCs, we did not find any significant difference at day 4 in $\mathrm{pDC}$ from mice receiving IFN- $\alpha$ as compared to controls (Fig. 15, A). However, at day 28, a significant upregulation ( 8 fold) of the 1 do 1 gene was detected in pDCs from IFN- $\alpha$-treated mice (Fig. 15, A). Western blot analyses confirmed the up-regulation of the IDO1 protein in pDCs from IFN- $\alpha$-treated mice as compared to untreated animals at 28 but not at day 4 of AIA (Fig. 15, B). 


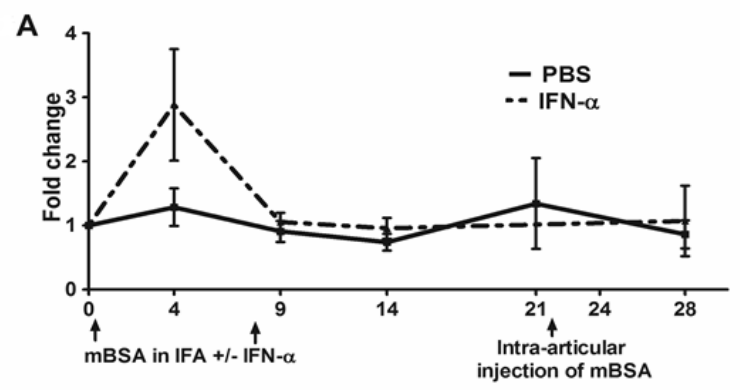

B

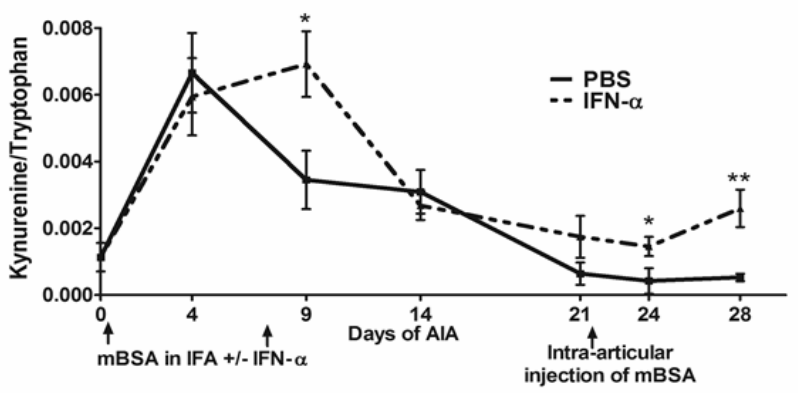

Figure 12. The protective effect of IFN- $\alpha$ in AIA is accompanied by induction of IDO1 expression and activity. A) During AIA activated with or without IFN- $\alpha$ treatment, spleens were collected at day 0, 4, 10, 14, 21 and 28 and analysed for relative Ido1 mRNA by Real Time-PCR. Data are expressed as fold change normalized to the reference gene Actin $B$ and Ido1 gene expression in spleens from naïve mice, $\mathrm{n} \geq 4$. B). Sera were collected at day $0,4,10,14,21,24$ and 28 of AIA and analysed for Trp and Kyn concentration by HPLC. Data are expressed as the ratio of serum levels of Kyn to Trp, $n \geq 7$.

One immune-suppressive mechanism of IDO1 is via enzymatic catabolism of Trp that leads to Trp deprivation and the production of immune-regulatory Kyn (Mellor and Munn, 2004). We next determined the IDO1 enzymatic activity (Kyn/Trp ratio in serum) in mice untreated (control) or treated with IFN- $\alpha$. In both groups, the Kyn/Trp ratio was significantly increased up to day 4 , thereafter, in control mice, it gradually decreased and maintained baseline level during arthritis phase (Fig. 12, B). However, in IFN- $\alpha$-treated mice, the Kyn/Trp ratio remained higher at day 9 and again during arthritis phase (day 24 and 25) compared to control mice (Fig. 12B).

Taken together, IFN- $\alpha$-treatment resulted in the induction of IDO1 expression which can be detected in splenocytes at day 4 and in PDC at day 28 of AIA. Likewise, it also resulted in biphasic increase of IDO1 activity, the first occurring closely to the Ag sensitisation and the second to the i.a. antigen boosting.

We next asked whether IDO1 is critically required for IFN- $\alpha$-protection in AIA. Hence, we investigated the protective effect of IFN- $\alpha$ against AIA in mice lacking IDO1 expression (IDO1KO mice). Interestingly, the protective effect of IFN- $\alpha$, evident in the WT siblings, was 
completely lost in IDO1KO mice (Fig. 13, A). This suggests the critical necessity of IDO1 expression and activity for the protective effect of IFN- $\alpha$ in AIA.

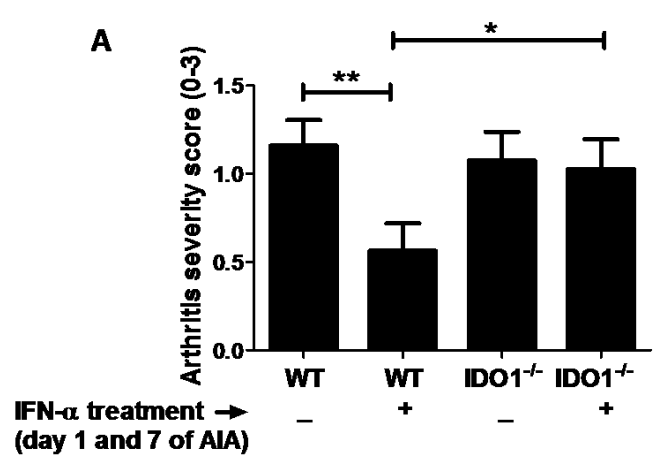

B

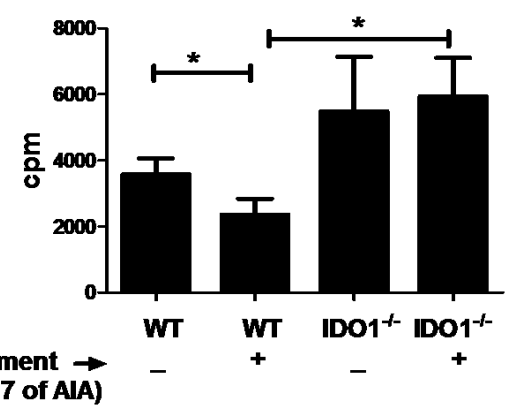

Figure 13. IDO1 expression is required for the protective effect of IFN- $\alpha$. AIA was induced in female Ido $1^{\%}$ and their wild type littermate mice with or without 1000 U IFN- $\alpha$ as described in Methods. (A) The level of arthritis evaluated at day 28 of AIA is expressed as severity score (mean \pm SEM, $\mathrm{n} \geq 16$ ) from $/ d o 1^{\%}$ mice and their WT littermates. (B) Splenocytes from day 28 of AIA were re-stimulated ex vivo with $50 \mu \mathrm{g} / \mathrm{ml}$ of mBSA for $72 \mathrm{hrs}$ and pulsed with radioactive thymidine for the last $20 \mathrm{hrs}$. The incorporated radioactivity (cpm-value) was determined by a beta counter. From the expressed values (mean cpm \pm SEM, $n=\geq 6$ ), the radioactivity (cpm) of the corresponding mock (medium) stimulation was subtracted. Comparison of arthritis severity score and cpm values for proliferation between different treatment groups was done by the Mann Whitney U test ${ }^{*} p<0.05$, $* * p<0.001)$.

In paper I, we reported that IFN- $\alpha$ protection was manifested by inhibiting proliferation of splenocytes and lymph nodes cells from IFN- $\alpha$ treated mice upon ex vivo mBSA restimulation (Fig. 6). To study whether the IFN- $\alpha$-induced inhibitory effect on leucocyte proliferation is dependent of IDO1, we investigated the mBSA-specific proliferation of splenocytes and lymph node cells ex-vivo from IDO1KO mice. IDO1 deficiency completely prevented the inhibitory effect of IFN- $\alpha$ on mBSA-induced proliferation of splenocytes restimulated ex vivo (Fig. 13, B). Thus, the mBSA-specific tolerance induced by IFN- $\alpha$ at sensitisation clearly relies on the presence of a functional IDO1. In agreement with our observation, Mellors' group has shown that the type I IFN inducer CpG-DNA is able to supress $\mathrm{T}$ cell proliferation via activation of IDO in an IFN- $\alpha$-dependent manner (Baban et al., 2005, Mellor et al., 2005).

In conclusion, these data suggest that the tolerogenic effect of IFN- $\alpha$ (arthritis protection plus the inhibition of mBSA-specific proliferation) is mediated by IDO1. In line with our observations, other studies have also shown the importance of IDO1 in mitigating collageninduced arthritis (Criado et al., 2009, Szanto et al., 2007a). In vitro studies have revealed that epigenetic modifications contribute to defective Treg cell function in RA due to inability to activate the IDO pathway, which further supports the anti-inflammatory role of IDO1 in arthritis (Cribbs et al., 2014). 


\section{The enzymatic pathway versus signalling pathway of IDO1 during IFN- $\alpha$ protection of AIA}

IDO1 exerts its immune-regulatory activity via an enzymatic as well as a signalling pathway (Fallarino et al., 2012). The enzymatic pathway can be abrogated by 1-MT that inhibits the IDO1 conversion of Trp into Kyn. To evaluate if the enzymatic activity of IDO1 is required for the protective effect of IFN- $\alpha$ in AIA, we administered 1-MT continuously either in drinking water or as slow-releasing pellets implanted s.c. into WT mice, either untreated or treated with IFN- $\alpha$, starting from day 1 until day 28 of AIA. In 1-MT-treated mice (from day 1 to 28), mice were not protected irrespectively of IFN- $\alpha$ treatment (Fig. 14 and paper III, supplementary Fig) confirming the requirement of IDO1 enzymatic activity.

We next asked at which time period of AIA, IDO1 enzymatic activity is important for IFN- $\alpha$ protection. As described in paper I, IFN- $\alpha$ should be present during antigen sensitisation for arthritis protection. To investigate if IFN- $\alpha$ protection requires enzymatic IDO1 activity during antigen sensitisation or arthritis phase, 1-MT was administered in pre-immunized animals continuously from day 21 , when arthritis was triggered by i.a. injection of mBSA, until the end of the experiment (day 28). In this way, the enzymatic activity of IDO1 was present in the sensitisation phase, but inhibited only in the inflammatory phase of AIA. Blocking the enzymatic activity of IDO1 in the inflammatory phase did not supersede the protective property of IFN- $\alpha$ (Fig. 14, A). In contrast, and as shown above (Fig. 13), administration of 1-MT starting at the time of antigen sensitisation totally abolished the protective effect of IFN- $\alpha$ (Fig. 14, A). These two observations clearly indicate that protection conferred by IFN- $\alpha$ is dependent on the enzymatic activity of IDO1 in the sensitisation phase, but not in the inflammatory phase of mBSA-induced arthritis. Importantly, under other circumstances the enzymatic activity of type I IFN-activated IDO1 can play a protective role in the arthritis phase of AIA (Huang et al., 2012). In the presence of the IDO-inhibitor 1-MT, the protection conferred by repeated injections of interferogenic DNA-nanoparticles is totally abolished (Huang et al., 2012). 
A

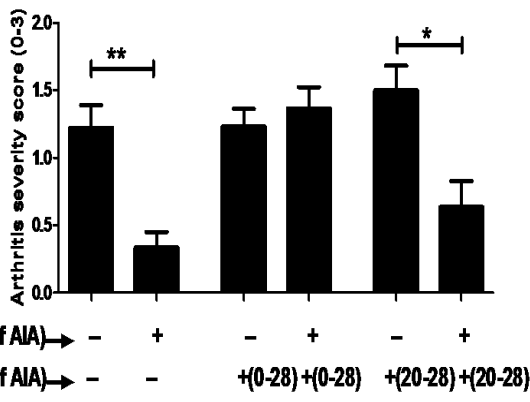

B

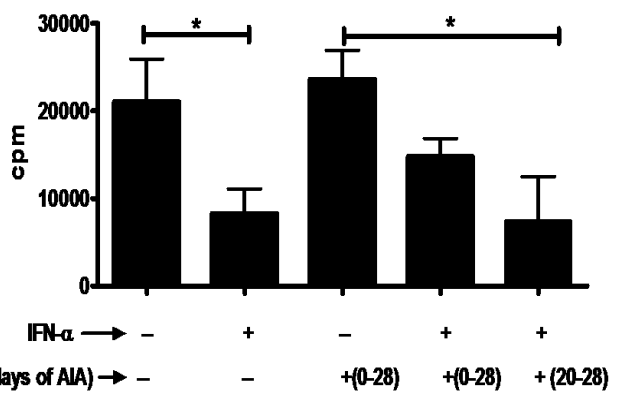

Figure 14. The enzymatic activity of IDO1 is required for the protective effect of IFN- $\alpha$ in the sensitisation but not in the disease onset phase. AIA was induced in female mice with or without IFN- $\alpha$ treatment as described in Methods. To inhibit the enzymatic activity of IDO1, 1-MT was administered by surgical insertion of a 1-MT pellet at day -1 to day 28 or day 20-28 of AIA. A) The level of arthritis expressed as severity score (mean \pm SEM, $\mathrm{n} \geq 7$ ) from WT mice that received 1-MT or vehicle and with or without IFN- $\alpha$ treatment. B) Splenocytes from WT mice at day 28 of AIA were re-stimulated ex vivo with $50 \mu \mathrm{g} / \mathrm{ml}$ of $\mathrm{mBSA}$ for $72 \mathrm{~h}$ and pulsed with radioactive thymidine for the last $20 \mathrm{~h}$. The incorporated radioactivity (cpm-value) was determined by a beta counter. From the expressed values (mean $\mathrm{cpm} \pm \mathrm{SEM}, \mathrm{n} \geq 7$.) the radioactivity (cpm) of the corresponding mock (medium) stimulation was subtracted. Comparison of arthritis severity score and cpm values for proliferation between groups was done by the Mann Whitney $U$ test $\left({ }^{*} p<0.05,{ }^{* *} p<0.001\right)$.

Considering these observations and previous observations of clear requirement of TGF- $\beta$ signalling in the sensitisation phase for IFN- $\alpha$-protection, but indispensable in arthritis phase, it is likely that IFN- $\alpha$ initiates a tolerogenic program against anti-mBSA immunity in the sensitisation phase. Indeed 1-MT, administered continuously from day -1 to day 28 but not on days $21-28$, hampered the inhibitory effect of IFN- $\alpha$ on proliferation of mBSAstimulated splenocytes and lymph node cells isolated at day 28 (Fig. 14, B). Thus the dampening effect of IFN- $\alpha$ on $\mathrm{mBSA}$-specific proliferation in the arthritis phase would follow that of the protective effect of IFN- $\alpha$ in AIA, i.e. it is dependent on IDO1 catalytic activity during the sensitisation but not in the arthritis phase.

Recently, TGF- $\beta$ was reported to activate the non-enzymatic signalling pathway of IDO1, especially in pDCs, leading to endogenous production of type I IFNs (Pallotta et al., 2011), which in turn induces and maintains long-term immune-tolerance (Pallotta et al., 2011, Pallotta et al., 2014). We therefore investigated the possible non-enzymatic IDO1 signalling pathway involved in IFN- $\alpha$-protection. The non-enzymatic IDO1 signalling pathway is in part characterized by non-canonical NF-KB activation involving nuclear translocation of both $\mathrm{p} 52$ and RelB subunits in pDC (Pallotta et al., 2011). Hence, we isolated splenic-pDCs from IFN- $\alpha$ treated mice at day 28 , re-stimulated them in absence or presence of IFN- $\alpha$ and evaluated the nuclear translocation of p52 and RelB by ELISA (Fig. 15, C). In vitro re-stimulation with IFN- $\alpha$, but with not medium alone, clearly promoted a significant translocation of both $\mathrm{p} 52$ and RelB subunits in nuclei. This ability to activate non-canonical NF-KB activation 
concomitant with sustained expression of both 1 do 1 and Tgf-beta transcripts in pDC at day 28 (Fig. 15, A\&B), indicates activation of non-enzymatic IDO signalling pathway during effector phase in IFN- $\alpha$ - treated mice.

A

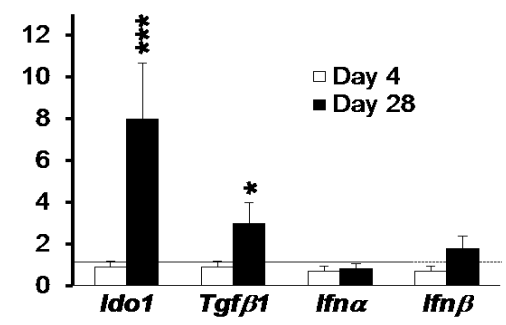

B

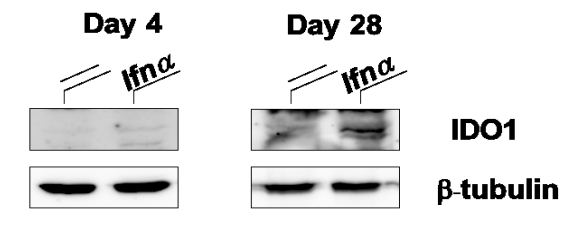

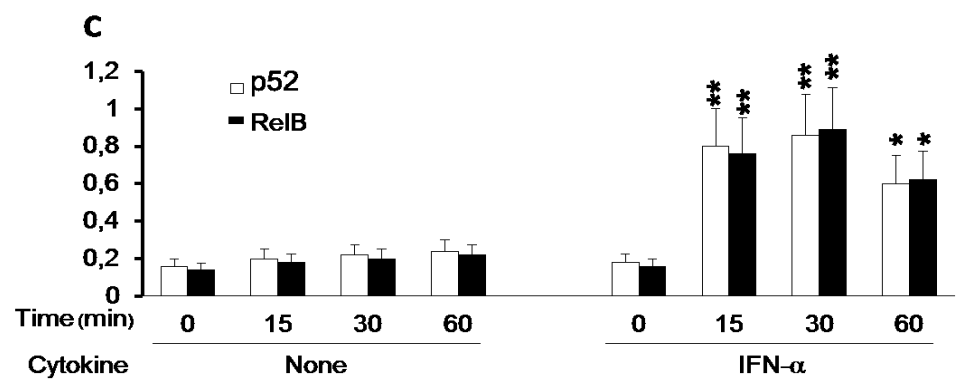

Figure 15. IFN- $\alpha$ induces IDO1 expression and signalling in splenic pDCs at day 28 of AIA. AIA was induced in female mice with IFN- $\alpha$ treatment as described in Methods. At days 4 and 28, mice were sacrificed and pDCs purified from their spleens. (A) Real-Time PCR analysis of Ido1, Tgfb1, Ifna11, and Ifnb1 transcripts in pDCs restimulated in vitro with IFN- $\alpha$, normalized to the expression of Actb and presented relative to results of untreated cells (dotted line, onefold). (B) Western blot analysis of IDO1 protein expression in pDCs restimulated or not re-stimulated in vitro with IFN- $\alpha$. $\beta$-tubulin was used as loading control. (C) Enzyme-linked immunosorbent assay of the activation of $\mathrm{p} 52$ and RelB in nuclear extracts of pDCs not re-stimulated with the cytokine (None) or re-stimulated for different times with IFN- $\alpha$. Results are presented as absorbance at $450 \mathrm{~nm}$ (A450). Data in (A) and (B) (mean \pm SD) were analysed by two-tailed, unpaired Student's t test. * $\mathrm{P}<0.05,{ }^{* *} \mathrm{P}<$ 0.01 , and $* * * \mathrm{P}<0.001$.

In conclusion, these data suggested the enzymatic activity of IDO1 is required for the protective effect of IFN- $\alpha$ in the sensitisation phase, whereas in the effector phase of AIA, the enzymatic activity, though active, is not necessary for protective effects of IFN- $\alpha$ in AIA. Instead, the signalling pathway of IDO1 is involved in the effector phase of AIA. By including a moderate dose at the time of encounter with an immunogen, type I IFN activates the enzymatic activity of IDO1 (Fig. 12, B) which promotes antigen-specific tolerance (Fig. 14), but subsequently this antigen-specific tolerance will be able to prevent inflammation weeks after the initial encounter with the immunogen in the absence of the enzymatic activity of IDO1 (Fig. 14). Upon re-encounter with the immunogen, non-enzymatic IDO1 signalling, including non-canonical NFkB activation (Fig. 15) and Kyn (Fig. 12), may manifest the actual anti-inflammatory properties of IFN. 


\section{Kyn, the major IDO1 product, ameliorates arthritis (Paper III)}

Kyn, the main metabolite derived from IDO1-mediated Trp catabolism, can exert antiinflammatory effects in vivo (Mezrich et al., 2010). The increased conversion of Trp to Kyn induced by IFN- $\alpha$ (Fig. 12) prompted us to determine if Kyn itself can prevent development of AIA in the absence of IFN- $\alpha$ treatment. To this end, we administered Kyn (15 mg per kg body weight) to mice at each sensitisation with mBSA similarly to IFN- $\alpha$ treatment. The severity of arthritis was significantly lower in mice receiving Kyn compared to control animals receiving vehicle alone (Fig. 16). Interestingly, this Kyn mediated protection was independent of endogenous type I IFN signalling, since IFNARKO mice were protected against arthritis by Kyn administration at a level comparable to that of WT mice (Fig. 16). In line with our results, Kyn (at a higher dose; $200 \mathrm{mg} / \mathrm{kg}$ ), ameliorated the severity of arthritis when given after onset of CIA (Criado et al., 2009). IDO1-mediated generation of Kyn may in fact be a natural way to prevent development of RA because IDO1 expression is defective among RA patients as compared to healthy controls (Cribbs et al., 2014). This may explain decreased serum levels of Kyn reported in RA (Cribbs et al., 2014).

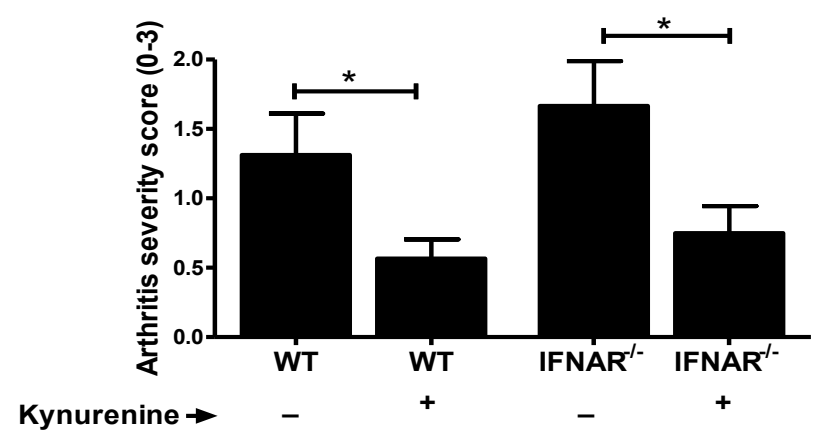

Figure 16. Kyn, the major IDO1 product, ameliorates arthritis. AIA was induced in WT or IFNARKO female mice with or without Kyn treatment ( $15 \mathrm{mg} / \mathrm{kg}$ mouse weight) during sensitisation of AIA as described in Methods. The level of arthritis is expressed as severity score (mean $\pm S E M, n \geq 7$ ). Comparison of arthritis severity score between groups was done by the Mann Whitney $U$ test $(* p<0.05)$.

Kyn may propagate tolerance without further help from IDO1, which may explain why 1-MT did not abolish protection in the arthritis phase (Fig 14). Once Kyn is generated from by IDO1 competent $C D 8^{+} \mathrm{DCs}$, this Kyn is able to activate the suppressive pathway, e.g., inhibition of delayed type hypersensitivity, in CD8- DC not expressing IDO1 (Belladonna et al., 2006). In AIA, we observed significantly higher levels of Kyn in IFN- $\alpha$-treated mice (Fig. 12). This was seen, not only in the sensitisation phase where the enzymatic activity of IDO1 exerts its tolerogenic effect, but also in the arthritis phase, albeit at a lesser magnitude (Fig. 12). Thus, IFN- $\alpha$ may first activate the expression and enzymatic activity of IDO1 and the Kyn generated from this enzymatic activity may propagate tolerance independently of the enzymatic activity of IDO1, resulting in protection against AIA in the arthritis phase, which does not anymore rely on IFN- $\alpha$-mediated activation of IDO1. 


\section{Regulatory T cells and IFN- $\alpha$ protection against arthritis (Paper IV)}

Regulatory $T$ cells are responsible for maintaining self-tolerance and for suppressing aberrant immune responses during infection and auto-inflammatory conditions (discussed in introduction). Considering our previous findings that IFN- $\alpha$ increases the Treg-inducers TGF$\beta$ (paper II), and IDO1 (paper III), together with several previous reports that type I IFN has pro-Treg activities (described in introduction), we hypothesised that Treg cells might be important in IFN- $\alpha$-protection against AIA. In paper IV, we investigated the importance of Treg cells for IFN- $\alpha$-protection against AIA.

\section{IFN- $\alpha$ enhances regulatory $T$ cells during AIA}

First, we quantified the percentage of Treg cells (Foxp3 ${ }^{+} \mathrm{T}$ cells) among $\mathrm{CD} 4^{+}$cells in blood collected at day $0,4,10,15,20,24$ and 28 of AIA from IFN- $\alpha$-treated and non-treated mice We observed an increase in percentage of Foxp $3^{+} \mathrm{CD}_{4}^{+}$T cells at day 4 of AIA in IFN- $\alpha-$ treated mice (red line) as compared to the untreated ones (blue line) (Fig. 17, A). This early increase in Treg cells in blood of IFN- $\alpha$-treated mice was dependent on TGF- $\beta$ as no increase in Treg cells was observed when TGF- $\beta$ was neutralized by anti-TGF- $\beta$ antibodies in IFN- $\alpha$ treated mice (Fig. 17A, green line). The increased level of Treg cells was maintained up to day 10 in IFN- $\alpha$-treated mice, but with no differences compared to untreated mice. After day 10, the level of Treg cells from both groups diminished sharply to baseline (Fig. 17). We predicted that the earlier increased number of Treg cells might end up in peripheral lymphoid organs like the spleen and lymph nodes. In fact, during the entire period of AIA, minor trends of increased Tregs (Foxp3 ${ }^{+} \mathrm{T}$ cells among $\mathrm{CD}^{+}$) cells were observed in spleens (day 4, 10 and 28) and lymph nodes (day 4 and 28) from mice treated with IFN- $\alpha$ as compared to controls, although no comparison on a single day was significant (Paper IV, Fig. 2). 


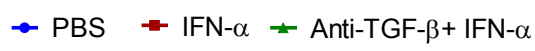

A

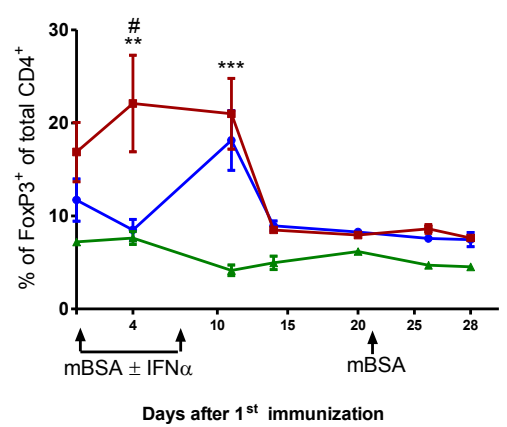

B

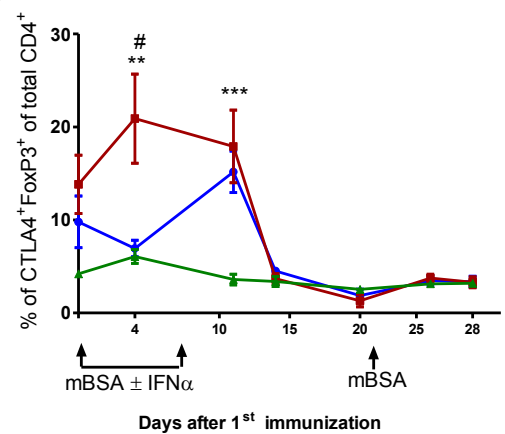

Figure 17. IFN- $\alpha$ increases TGF- $\beta$ dependent circulatory regulatory T cells during AIA. AIA was proceeded in female mice treated with PBS (control, blue line) or $1000 \mathrm{U}$ IFN- $\alpha$ (red line) as described in the methods section. TGF- $\beta$ signalling was blocked in some mice (green line) receiving IFN- $\alpha$ by daily i.p injection of $150 \mu \mathrm{g}$ anti-TGF- $\beta$ antibody for the first 0-9 days of AIA. Blood was collected at day 0, 4, 10, 15, 20, 24 and 28 of AIA and analysed by FACS. A) Percentage of Foxp $3^{+}$T cells of gated CD4 $4^{+}$cells in blood collected at day $0,4,10,15$, 20, 24 and 28 of AIA FACS. B) Percentage of CTLA $-4^{+}$Foxp $3^{+}$cells of gated CD $4^{+}$T cells. $n=\geq 5$. Comparison of groups with different treatment was done by student $t$ test $(\# p<0.05$ between PBS and IFN- $\alpha$ treated group, $* *$ $p<0.01 * * * p<0.001$ between PBS and IFN- $\alpha+$ anti-TGF- $\beta$ treated group.

Cytotoxic T-lymphocyte associated protein 4 (CTLA-4) expressed by Treg cells is a negative regulator of T cell proliferation and can be essential for the suppressive function of Treg cells (Wing et al., 2008). FACS analysis revealed the increased Foxp3 positive cells observed in IFN- $\alpha$-treated mice were expressing CTLA-4 (Fig. 17, B). This increased levels of CTLA-4 ${ }^{+}$Foxp $3^{+} \mathrm{CD} 4^{+}$cells in IFN- $\alpha$-treated mice was abolished when TGF- $\beta$ was neutralized by administration of anti-TGF- $\beta$ antibodies (Fig. 17, B, green line).

Recently, it was reported that type I IFN directly inhibits the proliferation of Treg cells during acute lymphocytic choriomeningitis virus infection (Srivastava et al., 2014). On the contrary, we here found an increase in the percentage of Treg cells in IFN- $\alpha$-treated mice in the AIA model. To further address this differential effect of type I IFN on Treg cells, we isolated leucocytes from naïve mice and from mBSA-sensitized mice during AIA, and stimulated them with anti-CD3 or mBSA in the presence or absence of IFN- $\alpha$ for 72 hours. In naïve leucocytes, we did not observe any in vitro effect of IFN- $\alpha$ on the quantity of Treg cells (Foxp $3^{+} \mathrm{CD} 4{ }^{+} \mathrm{T}$ cells). In contrast to naïve leucocytes, in presence of IFN- $\alpha$, the percentage of Treg cells was increased in the mBSA-sensitized leucocytes isolated at day 4 and 10 of AIA as compared to the same cultures without IFN- $\alpha$ (Fig. 18). This enhancing effect of IFN- $\alpha$ was antigen-specific as no increase in percentage of Treg cells was observed when stimulated with anti-CD3 antibodies. On the contrary, the Treg cells percentage tended to decrease at day 10 and day 
20 in IFN- $\alpha$-treated cells (Fig. 18, B). These data imply that IFN- $\alpha$ might have different effects on Treg cell homeostasis in antigen-sensitized and non-sensitized leucocytes.

A

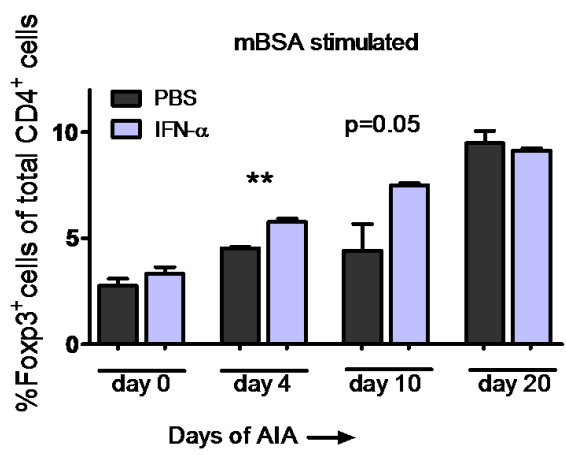

B

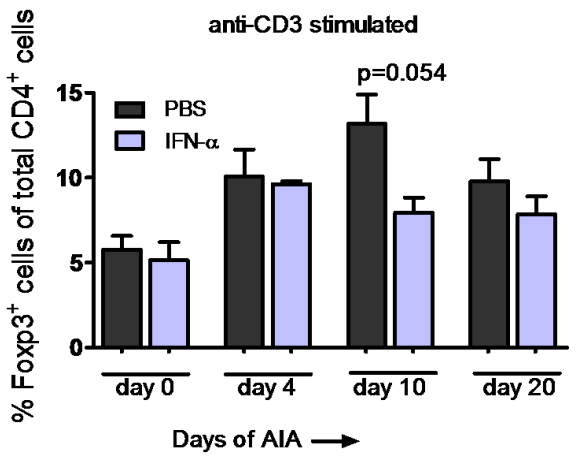

Figure 18. IFN- $\alpha$ induces regulatory $T$ cells when in vivo sensitized leucocytes were re-stimulated ex vivo. Spleens and lymph nodes were collected from PBS at day 0, 4, 10, and 20 of AIA. Splenocytes and lymph node cells were pooled and stimulated ex vivo with mBSA or anti-CD3 for 72 hours in the presence or absence of IFN- $\alpha(500 \mathrm{U} / \mathrm{ml})$. After 72 hours, the cells were analysed by FACS for Treg cells quantification. A) Percentage Foxp $3^{+} T$ cells of gated $\mathrm{CD}^{+}$cells from mBSA-stimulated cells. B) Percentage Foxp $3^{+} T$ cells of gated $C D 4^{+}$cells from anti-CD3 stimulated cells. $n=\geq 5$, Student $t$ test was used to compare PBS and IFN- $\alpha-$ treated group. $\left.\left.{ }^{*} p<0.05\right),{ }^{* *} p<0.01\right)$.

\section{Regulatory T cells mediate the IFN- $\alpha$-protection against AIA}

Our next task was to elucidate whether the protection conferred by IFN- $\alpha$ against AIA was dependent on Treg cells or not. To this end, we utilized DEREG mice where the Foxp3 ${ }^{+} \mathrm{T}$ cell population can be depleted for a limited period in vivo by administration of DT (see method). We evaluated the IFN- $\alpha$-protective effect against arthritis by depleting Foxp $3^{+} \mathrm{T}$ cells at various time periods of AIA. When Treg cells were depleted during the sensitisation phase (around day 1 or around day 7), the protective effect of IFN- $\alpha$ in AIA was not hampered (Fig. 19). However, in mice where Foxp $3^{+} \mathrm{T}$ cells were depleted around day 21 , (i.e. the time point of arthritis induction by intra-articular injection of $\mathrm{mBSA}$ ), the protective effect of IFN- $\alpha$ was totally abolished (Fig. 19). This indicates that Treg cells are critically required for IFN- $\alpha$ protection in the arthritis phase of AIA but redundant during sensitisation phase where TGF$\beta$ and the enzymatic activity IDO1 are critical (see Fig. $11 \& 14$ ). 


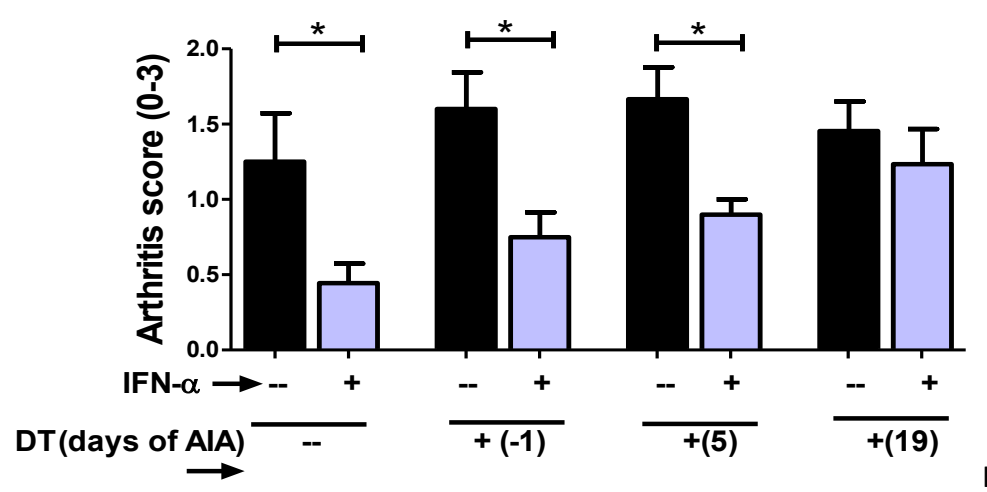

Figure 19. Regulatory T cells mediate the IFN- $\alpha$-protection against AIA. AIA was induced in female Foxp3DTReGFP ${ }^{+/-}$or their wild type littermates Foxp3DTReGFP-/- with or without $1000 \mathrm{U}$ IFN- $\alpha$ as described in Methods. DT was administered i.p at day -1 or 5 or 19 of AIA for transient depletion of Foxp3 ${ }^{+}$T cells. The level of arthritis evaluated at day 28 of AIA is expressed as severity score (mean $\pm S E M, n \geq 7$ ). Comparison of arthritis severity score between different IFN- $\alpha$ treated and non-treated groups was done by the Mann Whitney $U$ test $(* p<0.05)$.

\section{IFN- $\alpha$ treatment in vivo increases the in vitro suppressive activity of regulatory $T$ cells}

We next investigated the suppressive function of Treg cells from IFN- $\alpha$-treated mice (IFN- $\alpha$ Treg cells) compared to Treg cells from non-treated mice (control-Treg cells). Treg cells $\left(C D 4^{+} C D 25^{\text {high }}\right)$ were isolated at day 4,10 , and 20 of AIA from mice treated or not treated with IFN- $\alpha$ at day 1 and 7. A fixed amount of responder T cells (Tresp cells, CD4 $4^{+} \mathrm{CD} 25^{-}$) from mBSA-sensitized mice were co-cultured with various numbers of Treg cells in the presence of mBSA or anti-CD3 for 72 hours and proliferation of Tresp cells was assessed (see methods). IFN- $\alpha$-Treg cells isolated at day 10 and 20 , but not day 4 , exhibited higher suppression of mBSA-induced proliferation of Tresp cells compared to control-Treg cells (Fig. 20, left panels). However, only at day 20 did the IFN- $\alpha$ Treg cells show enhanced function against strongly anti-CD3-induced Treg cell proliferation (Fig. 20, right panels). In fact, IFN- $\alpha$-Treg cells isolated at day 10 showed a lower degree of suppression against anti-CD3-stimulated Tresp cells as compared to control-Treg cells (Fig. 20 B, right). Taken together, these data indicate that the suppressive capacity of Treg cells from IFN- $\alpha$-treated mice gets better with time: initially (at day 10 of AIA) in an antigen-specific manner, and later (at day 20 of AIA, just before induction of arthritis) in both antigen-specific and non-specific manner. 


\section{$\square$ PBS $\square$ IFN- $\alpha$}

A

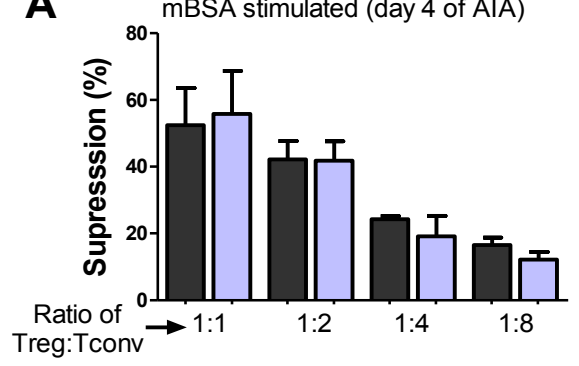

B

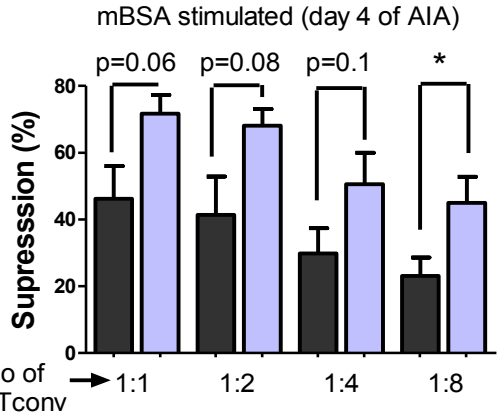

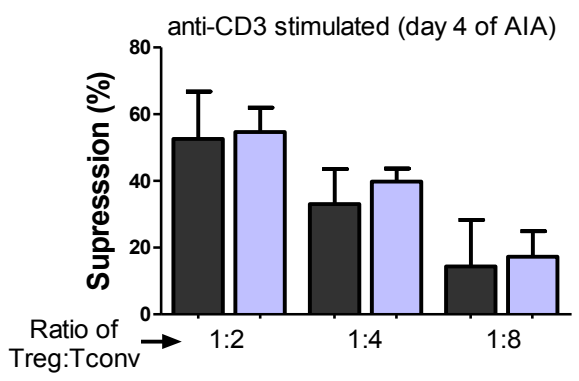

anti-CD3 stimulated (day 10 of AIA)

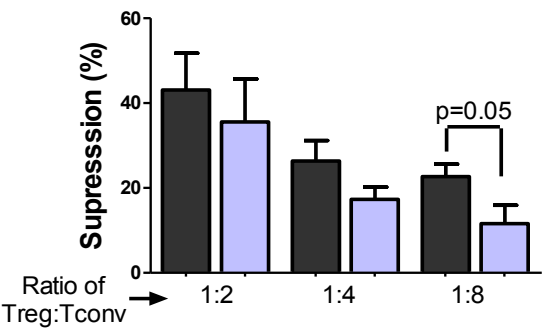

C
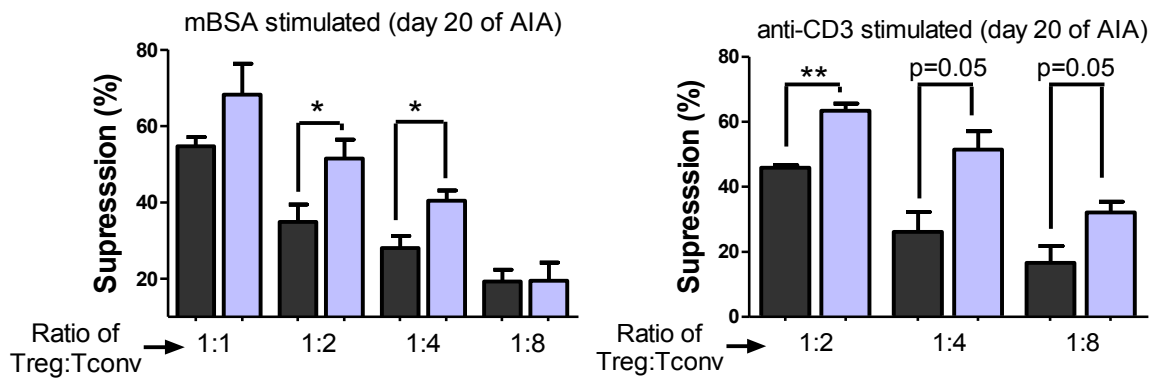

Figure 20. In vivo IFN- $\alpha$-treatment enhances in vitro suppressive capacity of Treg cells against proliferation of Tresp cells from untreated mice during AIA. AIA proceeded in female WT mice with or without $1000 \mathrm{U}$ IFN- $\alpha$ as described in Methods. Treg cells (CD4 ${ }^{+} \mathrm{CD} 25^{\text {high }}$ ) from IFN- $\alpha$-treated or non-treated mice and Tresp cells, (CD4+ ${ }^{+}$25 $\left.5^{-}\right)$from non-treated mice only was isolated at day 4, 10, and 20 of AIA and suppression assay was run as described. Suppression against proliferation of Tresp cells by Treg cells at decreasing Treg:Tresp cell ratios after $72 \mathrm{~h}$ culture in the presence of mBSA or anti-CD3 was calculated as described in Methods. A, B, C) Percent suppression by Treg cells isolated from PBS or IFN- $\alpha$ treated mice at day 4 (A) or day 10 (B) or day 20 (C) against proliferation of Tresp cells (from untreated mice) isolated from same days of AIA and stimulated with mBSA (right) or anti-CD3 (left). $n=\geq 4$, Student $t$ test was used to compare PBS and IFN- $\alpha$-treated group. * $\mathrm{p}<0.05), * * p<0.01$ 


\section{Adoptive transfer of Treg cells from mBSA-immunized mice protects against mBSA-induced arthritis}

After having scrutinized the development of Treg cells with enhanced suppressive function in IFN- $\alpha$ treated mice during AIA (Fig. 20), we asked if the protective effects of IFN- $\alpha$ in AIA could be transferred by Treg cells. Therefore, at day 20 from AIA induction, we isolated Treg cells (CD4 $\left.{ }^{+} \mathrm{CD} 25^{\text {high }}\right)$ from IFN- $\alpha$-treated or non-treated mice, and transferred the Treg cells to other mBSA-sensitized mice (day 20 of AIA). Arthritis was then induced in the recipient mice by intra-articular injection of $\mathrm{mBSA}$ and the severity of arthritis was evaluated at day 28. Mice receiving 250000 Treg cells from both IFN- $\alpha$ treated and non-treated mice were clearly protected against arthritis (data not shown). This shows that Treg cells from antigensensitized mice, regardless of IFN- $\alpha$ treatment, have the capability to prevent development of antigen-induced arthritis. 


\section{CONCLUDING REMARKS}

Type I IFNs (IFN- $\alpha$ and IFN- $\beta$ ) are a regular choice of therapy for certain diseases like hepatitis and multiple sclerosis. However type IFNs are extensively pleotropic cytokines; their biological effects can be both pro-inflammatory and anti-inflammatory depending on the context of inflammation. Their therapeutic effects are often impaired by its proinflammatory (Trinchieri, 2010) and toxic side effects (Sleijfer et al., 2005). So, delineation of their diverse effects by elucidating the downstream pathways of type I IFN signalling can open new therapeutic strategies for immune-related disorders. In this thesis, we tried to unfold and explore the anti-inflammatory aspects of type I IFN in the context of experimental arthritis.

In paper I, we broke our former belief that type I IFN and inducer of type I IFN (dsRNA) have pro-inflammatory role in arthritis, by showing that IFN- $\alpha$ can also protects against AIA. However, to protect against AIA, IFN- $\alpha$ must be present during the antigen sensitisation as it did not confer protection when antigen immunity is already established. We then attempted to explore the underlying mechanism of this IFN- $\alpha$-tolerance by studying the effect of IFN- $\alpha$ on various immune components during the course of AIA. In paper I and II, we investigated the effect of IFN- $\alpha$ on humoral immunity by analysing antigen-specific IgG, IgA, IgE during AIA, but we did not find differences in the level of those antibodies in serum between IFN- $\alpha$ treated mice and non-treated mice, which may suggest that humoral immunity is of less importance for the IFN- $\alpha$-tolerance in AIA. However, we did find that cellular immunity was involved in IFN- $\alpha$-protection as IFN- $\alpha$ delayed and decreased the leucocyte proliferative response against antigen. More importantly, IFN- $\alpha$, given during antigen sensitisation, prevented the recall proliferative responses induced by antigenic re-challenge in joints after four weeks of first antigen sensitisation.

In paper II, we performed a descriptive, hypothesis-generating study of the modulation of cytokines associated with IFN- $\alpha$-mediated protection against arthritis. Presence of IFN- $\alpha$ at sensitisations hampered the antigen-specific increase of pro-inflammatory cytokines twice during AIA: first after two weeks of first sensitisation and second during the arthritis manifestation which is after four weeks from first sensitisation. In contrast, IFN- $\alpha$ enhanced the levels of TGF- $\beta$ at the time when the pro-inflammatory cytokines were inhibited.

In paper III, we found that the protective effect of IFN- $\alpha$ was mediated by TGF- $\beta$ and also by an immune-regulatory molecule IDO1 which was activated by IFN- $\alpha$ during AIA. We, then investigated the two different mechanisms (enzymatic and non-enzymatic) of IDO1's immune-suppressive effect in IFN- $\alpha$-treated mice. IDO1 enzymatic activity was found crucial only during antigen sensitisation but dispensable at effector phase of AIA for IFN- $\alpha$ protective effect. Instead, IDO1's non-enzymatic activity was observed clearly in effector phase in mice treated with IFN- $\alpha$. Furthermore, in paper III we identified Kynurenine, a metabolite of IDO1, as a key molecule in IFN- $\alpha$-protection that can protect against arthritis independently of type I IFN. 
In paper IV, we focused on modulation of regulatory T cells by IFN- $\alpha$ treatment during AIA. Treg cells were found to be indispensable for IFN- $\alpha$-protection in AIA but only during induction of arthritis and not in the sensitisation phase. In addition, we showed that IFN- $\alpha$ enhances the suppressive function of Treg cells during AIA in a time and antigen dependent manner. Finally, we showed that adoptive transfer cells Treg cells from mBSA-sensitised mice prevents the development of arthritis induced by mBSA re-challenge in pre-sensitised mice.

Overall, in this thesis, we showed that presence of IFN- $\alpha$ during antigen sensitisation induces a state of tolerance against antigen, which later prevents joint inflammation induced by antigenic re-challenge (paper I-IV). The observed IFN- $\alpha$-mediated tolerogenic effect is shaped initially by TGF- $\beta$ and IDO1 (paper III) during antigen sensitisation that modulates T cells homeostasis resulting in the inhibition of pro-inflammatory cytokines (paper II) and the enhancement of Treg cells (paper IV). We have thus identified molecular and cellular components of the anti-inflammatory program (tolerance) elicited by IFN- $\alpha$ including Kyn that may not have the pro-inflammatory effects associated with IFN- $\alpha$. The model we have used to show IFN- $\alpha$-mediated tolerance is a mild model of arthritis. The next goal is to translate this tolerance to a more severe model of arthritis as well other inflammatory models. 


\section{ACKNOWLEDGEMENTS}

Mattias Magnusson, my main supervisor. Foremost, I would like to express my sincere gratitude for believing in me and giving me opportunity to do PhD under your supervision. Your all-round support and your ever-positive, super-optimistic and inspiring attitude made me feel comfortable during my entire studies. I started immunology research from scratch and now I am about to hold a PhD in immunology. All credit goes to you!!! Thank you for your excellent supervision.

Thomas Skogh, my co-supervisor, thanks for your encouragement and kind support during my studies. Though I was not involved in the projects that were directly connected to you, I am grateful for your kind suggestions and comments on my projects especially humoral immunity aspects and also for your scrutinizing my writing that improved my thesis a lot.

Jonas Wetterö: Thank you very much for your kind all-round support and guidance during my studies. You were always there (while my supervisor's chair was mostly empty) to listen and help me whenever I needed anything.

Jan Ernerudh: Your cool, friendly, supportive, uniquely humorous and highly knowledgeable personality is a big inspiration for me. I wish to be like you in future. Thanks for your valuable suggestions and comments on my research projects.

Maria Jenmalm: I am impressed with your deep knowledge in theoretical and practical aspect of immunology. Thanks for your suggestions and comments regarding my research which helped to improve a lot. Your personality has always motivated me to enhance the competitiveness in research.

Said Havarnisaab: Thanks for the useful discussions and your valuable suggestions regarding my research projects. And thank you and Per Hultman for allowing to use your laboratory for some experiments.

Sudeep Chenna Narendra: what to say about you!!! We will talk later several hours about you $;$. We started projects together and we were together most of the time in office and in most of the big experiments. I will miss you very much.

Liv Gröntoft: You are a person with full of life. It was always comfortable and great fun to be with you. Thank you very much for your kind care which made my stay in Sweden lively, homely and unforgettable. And it was always great to chat with you and Bo Häggqvist during the lunch time.

Hammoudi Alkaissai: How can I forget you!!! You were there every time to make my stay in Linköping very easy, happy and encouraging both in academic and non-academic aspects. Thanks very much for your contribution and support regarding my research projects as well other fun stuffs. 
Christer Bergman: Very funny, very helpful, always make the mood better all the time I talked to you. Whenever there was some problem, Christer would find a solution for me. I am really grateful for your help.

Ratnesh Bhai Mehta: From outside, seemingly critical and harsh to me, from inside you were always kind, helpful and supportive to me $)$. Thanks for your help in my research projects.

Johanna Huoman: Thank you very much for scrutinizing my thesis in a very short time. I always feel great to talk to you.

I take this opportunity to express gratitude to all of my current and previous colleagues and members in the department for their help, support and for making pleasant and friendly atmosphere in the AIR department: Linda Fryland, Helena Enconsson, Daniela Patinha Sandra Hellberg, Anna Forsberg, Judit Svensson-Arvelund, Lina Wirestam, Marie Rubér, Daniel Eklund, Robert Lindau, Måns Edström, Klara Martinsson, Karin Söderman, Annemarie Fornander, Ylva Billing, Marie-Ann, Gunnel, Marie Malander.

I would like to specially thank Petra Cassel for helping and guiding me for LUMINEX experiments and other laboratory \& administrative stuffs.

I would like to thank all my colleagues from Masters studies especially Mayur, Miraj, Sandeep, Cecillia, Elmira and Rebecca. You should know that the memorable fun moments we had together, starting from 2009 till now, do worth more than I can express on this paper.

Students: To previous master students: Jesper Lindh, Erik Ljunggren, Bhesh Raj Paudel, Emelie Larsson, Hanna Hillman and Zara. It was nice to work and share my practical and theoretical knowledge with you.

And to current master students who are brilliant and co-operative Joanitah Namale and Sophie Biggs.

Ravi Kumar Dutta: You are the only Nepali left in the city who I can talk, behave, eat and celebrate in a Nepali way $;$. Your presence have reduced the missing's of Nepal. Thanks for all the time we spend in Linköping from 2010.

Finally, to my family members, relatives, friends and people from Nepal who have directly/indirectly supported and encouraged me in various aspects of life. 


\section{REFERENCES}

\section{Uncategorized References}

ABBAS, A. K., BENOIST, C., BLUESTONE, J. A., CAMPBELL, D. J., GHOSH, S., HORI, S., JIANG, S., KUCHROO, V. K., MATHIS, D., RONCAROLO, M. G., RUDENSKY, A., SAKAGUCHI, S., SHEVACH, E. M., VIGNALI, D. A. \& ZIEGLER, S. F. 2013. Regulatory T cells: recommendations to simplify the nomenclature. Nat Immunol, 14, 307-8.

ALLEN, J. B., MANTHEY, C. L., HAND, A. R., OHURA, K., ELLINGSWORTH, L. \& WAHL, S. M. 1990. Rapid onset synovial inflammation and hyperplasia induced by transforming growth factor beta. $J$ Exp Med, 171, 231-47.

ALZABIN, S. \& WILLIAMS, R. O. 2011. Effector T cells in rheumatoid arthritis: lessons from animal models. FEBS Lett, 585, 3649-59.

ASQUITH, D. L., MILLER, A. M., MCINNES, I. B. \& LIEW, F. Y. 2009. Animal models of rheumatoid arthritis. Eur J Immunol, 39, 2040-4.

ASSELIN-PATUREL, C., BRIZARD, G., PIN, J. J., BRIERE, F. \& TRINCHIERI, G. 2003. Mouse strain differences in plasmacytoid dendritic cell frequency and function revealed by a novel monoclonal antibody. J Immunol, 171, 6466-77.

AXTELL, R. C., DE JONG, B. A., BONIFACE, K., VAN DER VOORT, L. F., BHAT, R., DE SARNO, P., NAVES, R., HAN, M., ZHONG, F., CASTELLANOS, J. G., MAIR, R., CHRISTAKOS, A., KOLKOWITZ, I., KATZ, L., KILLESTEIN, J., POLMAN, C. H., DE WAAL MALEFYT, R., STEINMAN, L. \& RAMAN, C. 2010. T helper type 1 and 17 cells determine efficacy of interferon-beta in multiple sclerosis and experimental encephalomyelitis. Nat Med, 16, 406-12.

BABAN, B., HANSEN, A. M., CHANDLER, P. R., MANLAPAT, A., BINGAMAN, A., KAHLER, D. J., MUNN, D. H. \& MELLOR, A. L. 2005. A minor population of splenic dendritic cells expressing CD19 mediates IDO-dependent T cell suppression via type I IFN signaling following B7 ligation. Int Immunol, 17, 909-19.

BACHER, N., RAKER, V., HOFMANN, C., GRAULICH, E., SCHWENK, M., BAUMGRASS, R., BOPP, T., ZECHNER, U., MERTEN, L., BECKER, C. \& STEINBRINK, K. 2013. Interferon-alpha suppresses CAMP to disarm human regulatory T cells. Cancer Res, 73, 5647-56.

BANCHEREAU, J. \& PASCUAL, V. 2006. Type I interferon in systemic lupus erythematosus and other autoimmune diseases. Immunity, 25, 383-92.

BAVE, U., MAGNUSSON, M., ELORANTA, M. L., PERERS, A., ALM, G. V. \& RONNBLOM, L. 2003. FC gamma Rlla is expressed on natural IFN-alpha-producing cells (plasmacytoid dendritic cells) and is required for the IFN-alpha production induced by apoptotic cells combined with lupus IgG. Journal of Immunology, 171, 3296-3302.

BELLADONNA, M. F., FALLARINO, F., PALLOTTA, M. T., ORABONA, C., VOLPI, C., BIANCHI, C., VACCA, C., GROHMANN, U. \& PUCCETTI, P. 2011. The role of TGF-beta as tolerogenic cytokine in regulating dendritic cell function. Cytokine, 56, 15-15.

BETTELLI, E., CARRIER, Y., GAO, W., KORN, T., STROM, T. B., OUKKA, M., WEINER, H. L. \& KUCHROO, V. K. 2006. Reciprocal developmental pathways for the generation of pathogenic effector TH17 and regulatory T cells. Nature, 441, 235-8.

BLUESTONE, J. A. 2011. Mechanisms of tolerance. Immunol Rev, 241, 5-19.

BOKAREWA, M., TARKOWSKI, A., LIND, M., DAHLBERG, L. \& MAGNUSSON, M. 2008. Arthritogenic dsRNA is present in synovial fluid from rheumatoid arthritis patients with an erosive disease course. Eur J Immunol, 38, 3237-44.

BONILLA-HERNAN, M. G., MIRANDA-CARUS, M. E. \& MARTIN-MOLA, E. 2011. New drugs beyond biologics in rheumatoid arthritis: the kinase inhibitors. Rheumatology (Oxford), 50, 1542-50.

BRACKERTZ, D., MITCHELL, G. F., VADAS, M. A. \& MACKAY, I. R. 1977. Studies on antigen-induced arthritis in mice. III. Cell and serum transfer experiments. J Immunol., 118, 1645-8.

BRANDES, M. E., ALLEN, J. B., OGAWA, Y. \& WAHL, S. M. 1991. Transforming growth factor beta 1 suppresses acute and chronic arthritis in experimental animals. J Clin Invest, 87, 1108-13. 
BRUHNS, P. 2012. Properties of mouse and human IgG receptors and their contribution to disease models. Blood, 119, 5640-9.

BUGATTI, S., VITOLO, B., CAPORALI, R., MONTECUCCO, C. \& MANZO, A. 2014. B cells in rheumatoid arthritis: from pathogenic players to disease biomarkers. Biomed Res Int, 2014, 681678.

BURMESTER, G. R., FEIST, E. \& DORNER, T. 2014. Emerging cell and cytokine targets in rheumatoid arthritis. Nat Rev Rheumatol, 10, 77-88.

CALLARD, R. \& HODGKIN, P. 2007. Modeling T- and B-cell growth and differentiation. Immunol Rev, 216, 119-29.

CATRINA, A. I., DEANE, K. D. \& SCHER, J. U. 2014. Gene, environment, microbiome and mucosal immune tolerance in rheumatoid arthritis. Rheumatology (Oxford).

CEDERGREN, J., FORSLUND, T., SUNDQVIST, T. \& SKOGH, T. 2007. Intracellular oxidative activation in synovial fluid neutrophils from patients with rheumatoid arthritis but not from other arthritis patients. J Rheumatol, 34, 2162-70.

CHEN, M., CHEN, G., DENG, S., LIU, X., HUTTON, G. J. \& HONG, J. 2012. IFN-beta induces the proliferation of CD4+CD25+Foxp3+ regulatory T cells through upregulation of GITRL on dendritic cells in the treatment of multiple sclerosis. J Neuroimmunol, 242, 39-46.

CHEN, S. Y., WU, C. L., LAI, M. D., LIN, C. C., YO, Y. T., JOU, I. M., LEE, C. H., WENG, C. T., SHIAU, A. L. \& WANG, C. R. 2010. Amelioration of Rat Collagen-induced Arthritis through CD4+ T Cells Apoptosis and Synovial Interleukin-17 Reduction by Indoleamine 2,3-dioxygenase Gene Therapy. Human Gene Therapy.

CORR, M., BOYLE, D. L., RONACHER, L., FLORES, N. \& FIRESTEIN, G. S. 2009. Synergistic benefit in inflammatory arthritis by targeting I kappaB kinase epsilon and interferon beta. Ann Rheum Dis, 68, 257-63.

COSTENBADER, K. H. \& MANSON, J. E. 2008. Do female hormones affect the onset or severity of rheumatoid arthritis? Arthritis Rheum, 59, 299-301.

CRIADO, G., SIMELYTE, E., INGLIS, J. J., ESSEX, D. \& WILLIAMS, R. O. 2009. Indoleamine 2,3 dioxygenase-mediated tryptophan catabolism regulates accumulation of Th1/Th17 cells in the joint in collagen-induced arthritis. Arthritis Rheum, 60, 1342-51.

CRIBBS, A. P., KENNEDY, A., PENN, H., READ, J. E., AMJADI, P., GREEN, P., SYED, K., MANKA, S. W., BRENNAN, F. M., GREGORY, B. \& WILLIAMS, R. O. 2014. Treg cell function in rheumatoid arthritis is compromised by ctla-4 promoter methylation resulting in a failure to activate the indoleamine 2,3-dioxygenase pathway. Arthritis Rheumatol, 66, 2344-54.

CROUSE, J., KALINKE, U. \& OXENIUS, A. 2015. Regulation of antiviral T cell responses by type I interferons. Nat Rev Immunol, 15, 231-42.

CURTI, A., TRABANELLI, S., SALVESTRINI, V., BACCARANI, M. \& LEMOLI, R. M. 2009. The role of indoleamine 2,3-dioxygenase in the induction of immune tolerance: focus on hematology. Blood, 113, 2394-401.

DAI, W. \& GUPTA, S. L. 1990. Molecular cloning, sequencing and expression of human interferongamma-inducible indoleamine 2,3-dioxygenase cDNA. Biochem Biophys Res Commun, 168, 18.

DALGAARD, T. S., NORUP, L. R., RUBBENSTROTH, D., WATTRANG, E. \& JUUL-MADSEN, H. R. 2010. Flow cytometric assessment of antigen-specific proliferation in peripheral chicken $\mathrm{T}$ cells by CFSE dilution. Vet Immunol Immunopathol, 138, 85-94.

DAVIDSON, A. \& DIAMOND, B. 2001. Autoimmune diseases. N Engl J Med, 345, 340-50.

DE GORTER, D. J., VAN DINTHER, M., KORCHYNSKYI, O. \& TEN DIJKE, P. 2011. Biphasic effects of transforming growth factor beta on bone morphogenetic protein-induced osteoblast differentiation. J Bone Miner Res, 26, 1178-87.

EKERFELT, C., ANDERSSON, M., OLAUSSON, A., BERGSTROM, S. \& HULTMAN, P. 2007. Mercury exposure as a model for deviation of cytokine responses in experimental Lyme arthritis: $\mathrm{HgCl} 2$ treatment decreases $\mathrm{T}$ helper cell type 1-like responses and arthritis severity but delays eradication of Borrelia burgdorferi in C3H/HeN mice. Clin Exp Immunol, 150, 189-97. 
ENGLUND, M., JOUD, A., GEBOREK, P., FELSON, D. T., JACOBSSON, L. T. \& PETERSSON, I. F. 2010. Prevalence and incidence of rheumatoid arthritis in southern Sweden 2008 and their relation to prescribed biologics. Rheumatology (Oxford), 49, 1563-9.

FALLARINO, F., GROHMANN, U. \& PUCCETTI, P. 2012. Indoleamine 2,3-dioxygenase: from catalyst to signaling function. Eur $\mathrm{J}$ Immunol, 42, 1932-7.

FALLARINO, F., GROHMANN, U., YOU, S., MCGRATH, B. C., CAVENER, D. R., VACCA, C., ORABONA, C., BIANCHI, R., BELLADONNA, M. L., VOLPI, C., FIORETTI, M. C. \& PUCCETTI, P. 2006. Tryptophan catabolism generates autoimmune-preventive regulatory T cells. Transpl Immunol, 17, 58-60.

FLORES-BORJA, F., JURY, E. C., MAURI, C. \& EHRENSTEIN, M. R. 2008. Defects in CTLA-4 are associated with abnormal regulatory T cell function in rheumatoid arthritis. Proc Natl Acad Sci U S A, 105, 19396-401.

FONTENOT, J. D., GAVIN, M. A. \& RUDENSKY, A. Y. 2003. Foxp3 programs the development and function of CD4+CD25+ regulatory T cells. Nat Immunol, 4, 330-6.

FREY, O., PETROW, P. K., GAJDA, M., SIEGMUND, K., HUEHN, J., SCHEFFOLD, A., HAMANN, A., RADBRUCH, A. \& BRAUER, R. 2005. The role of regulatory T cells in antigen-induced arthritis: aggravation of arthritis after depletion and amelioration after transfer of CD4+CD25+ T cells. Arthritis Res Ther, 7, R291-301.

GAFFEN, S. L. 2008. An overview of IL-17 function and signaling. Cytokine, 43, 402-7.

GARBER, K. 2014. Immunology: A tolerant approach. Nature, 507, 418-20.

GATTORNO, M., CHICHA, L., GREGORIO, A., FERLITO, F., ROSSI, F., JARROSSAY, D., LANZAVECCHIA, A., MARTINI, A. \& MANZ, M. G. 2007. Distinct expression pattern of IFN-alpha and TNF-alpha in juvenile idiopathic arthritis synovial tissue. Rheumatology (Oxford), 46, 657-65.

GENOVESE, M. C., CHAKRAVARTY, E. F., KRISHNAN, E. \& MORELAND, L. W. 2004. A randomized, controlled trial of interferon-beta-1a $(\operatorname{Avonex}(R))$ in patients with rheumatoid arthritis: a pilot study [ISRCTN03626626]. Arthritis Res Ther, 6, R73-R77.

GENOVESE, M. C., DUREZ, P., RICHARDS, H. B., SUPRONIK, J., DOKOUPILOVA, E., MAZUROV, V., AELION, J. A., LEE, S. H., CODDING, C. E., KELLNER, H., IKAWA, T., HUGOT, S. \& MPOFU, S. 2013. Efficacy and safety of secukinumab in patients with rheumatoid arthritis: a phase II, dose-finding, double-blind, randomised, placebo controlled study. Ann Rheum Dis, 72, 863-9.

GONZALEZ-NAVAJAS, J. M., LEE, J., DAVID, M. \& RAZ, E. 2012. Immunomodulatory functions of type I interferons. Nat Rev Immunol, 12, 125-35.

HAFSTROM, I., ALBERTSSON, K., BOONEN, A., VAN DER HEIJDE, D., LANDEWE, R., SVENSSON, B. \& GROUP, B. S. 2009. Remission achieved after 2 years treatment with low-dose prednisolone in addition to disease-modifying anti-rheumatic drugs in early rheumatoid arthritis is associated with reduced joint destruction still present after 4 years: an open 2-year continuation study. Ann Rheum Dis, 68, 508-13.

HAFSTROM, I., ENGVALL, I. L., RONNELID, J., BOONEN, A., VAN DER HEIJDE, D., SVENSSON, B. \& GROUP, B. S. 2014. Rheumatoid factor and anti-CCP do not predict progressive joint damage in patients with early rheumatoid arthritis treated with prednisolone: a randomised study. BMJ Open, 4, e005246.

HASKO, G. \& CRONSTEIN, B. 2013. Regulation of inflammation by adenosine. Front Immunol, 4, 85.

HECHT, C., ENGLBRECHT, M., RECH, J., SCHMIDT, S., ARAUJO, E., ENGELKE, K., FINZEL, S. \& SCHETT, G. 2014. Additive effect of anti-citrullinated protein antibodies and rheumatoid factor on bone erosions in patients with RA. Ann Rheum Dis.

HOOKS, J. J., MOUTSOPOULOS, H. M., GEIS, S. A., STAHL, N. I., DECKER, J. L. \& NOTKINS, A. L. 1979. Immune interferon in the circulation of patients with autoimmune disease. $N$ Engl J Med, 301, 5-8.

HOPKINS, S. J. \& MEAGER, A. 1988. Cytokines in synovial fluid: II. The presence of tumour necrosis factor and interferon. Clin Exp Immunol, 73, 88-92.

HUANG, L., LEMOS, H. P., LI, L., LI, M., CHANDLER, P. R., BABAN, B., MCGAHA, T. L., RAVISHANKAR, B., LEE, J. R., MUNN, D. H. \& MELLOR, A. L. 2012. Engineering DNA nanoparticles as immunomodulatory reagents that activate regulatory T cells. J Immunol, 188, 4913-20. 
HUBER, J. P. \& FARRAR, J. D. 2011. Regulation of effector and memory T-cell functions by type I interferon. Immunology, 132, 466-74.

ISAACS, A. \& LINDENMANN, J. 1957. Virus interference. I. The interferon. Proc R Soc Lond B Biol Sci, $147,258-67$.

JEGO, G., PALUCKA, A. K., BLANCK, J. P., CHALOUNI, C., PASCUAL, V. \& BANCHEREAU, J. 2003. Plasmacytoid dendritic cells induce plasma cell differentiation through type I interferon and interleukin 6. Immunity, 19, 225-34.

JONULEIT, H. \& SCHMITT, E. 2003. The regulatory T cell family: distinct subsets and their interrelations. J Immunol, 171, 6323-7.

JOSEFOWICZ, S. Z., LU, L. F. \& RUDENSKY, A. Y. 2012. Regulatory T cells: mechanisms of differentiation and function. Annu Rev Immunol, 30, 531-64.

KAHLER, D. J. \& MELLOR, A. L. 2009. T cell regulatory plasmacytoid dendritic cells expressing indoleamine 2,3 dioxygenase. Handb Exp Pharmacol, 165-96.

KATAKURA, K., LEE, J., RACHMILEWITZ, D., LI, G., ECKMANN, L. \& RAZ, E. 2005a. Toll-like receptor 9induced type I IFN protects mice from experimental colitis. J Clin Invest, 115, 695-702.

KATAKURA, K., LEE, J., RACHMILEWITZ, D., LI, G., ECKMANN, L. \& RAZ, E. 2005b. Toll-like receptor 9induced type I IFN protects mice from experimental colitis (vol 115, pg 1100, 2005). Journal of Clinical Investigation, 115, 1100-1100.

KATZ, J. B., MULLER, A. J. \& PRENDERGAST, G. C. 2008. Indoleamine 2,3-dioxygenase in T-cell tolerance and tumoral immune escape. Immunol Rev, 222, 206-21.

KAUR, S., UDDIN, S. \& PLATANIAS, L. C. 2005. The PI3' kinase pathway in interferon signaling. J Interferon Cytokine Res, 25, 780-7.

KAY, J. \& CALABRESE, L. 2004. The role of interleukin-1 in the pathogenesis of rheumatoid arthritis. Rheumatology (Oxford), 43 Suppl 3, iii2-iiig.

KIELY, P. D., DEIGHTON, C., DIXEY, J., OSTOR, A. J., BRITISH SOCIETY FOR RHEUMATOLOGY STANDARDS, G. \& AUDIT WORKING, G. 2012. Biologic agents for rheumatoid arthritis-negotiating the NICE technology appraisals. Rheumatology (Oxford), 51, 24-31.

KIMURA, A. \& KISHIMOTO, T. 2010. IL-6: regulator of Treg/Th17 balance. Eur J Immunol, 40, 1830-5.

KLARESKOG, L., STOLT, P., LUNDBERG, K., KALLBERG, H., BENGTSSON, C., GRUNEWALD, J., RONNELID, J., HARRIS, H. E., ULFGREN, A. K., RANTAPAA-DAHLQVIST, S., EKLUND, A., PADYUKOV, L. \& ALFREDSSON, L. 2006. A new model for an etiology of rheumatoid arthritis: smoking may trigger HLA-DR (shared epitope)-restricted immune reactions to autoantigens modified by citrullination. Arthritis Rheum, 54, 38-46.

KLEYER, A., FINZEL, S., RECH, J., MANGER, B., KRIETER, M., FAUSTINI, F., ARAUJO, E., HUEBER, A. J., HARRE, U., ENGELKE, K. \& SCHETT, G. 2014. Bone loss before the clinical onset of rheumatoid arthritis in subjects with anticitrullinated protein antibodies. Ann Rheum Dis, 73, 854-60.

KOCIJAN, R., HARRE, U. \& SCHETT, G. 2013. ACPA and bone loss in rheumatoid arthritis. Curr Rheumatol Rep, 15, 366.

KUHN, K. A., KULIK, L., TOMOOKA, B., BRASCHLER, K. J., AREND, W. P., ROBINSON, W. H. \& HOLERS, V. M. 2006. Antibodies against citrullinated proteins enhance tissue injury in experimental autoimmune arthritis. J Clin Invest, 116, 961-73.

LAHL, K. \& SPARWASSER, T. 2011. In vivo depletion of FoxP3+ Tregs using the DEREG mouse model. Methods Mol Biol, 707, 157-72.

LE BON, A., SCHIAVONI, G., D'AGOSTINO, G., GRESSER, I., BELARDELLI, F. \& TOUGH, D. F. 2001. Type i interferons potently enhance humoral immunity and can promote isotype switching by stimulating dendritic cells in vivo. Immunity, 14, 461-70.

LE BUANEC, H., GOUGEON, M. L., MATHIAN, A., LEBON, P., DUPONT, J. M., PELTRE, G., HEMON, P., SCHMID, M., BIZZINI, B., KUNDING, T., BURNY, A., BENSUSSAN, A., AMOURA, Z., GALLO, R. C. \& ZAGURY, D. 2011. IFN-alpha and CD46 stimulation are associated with active lupus and skew natural T regulatory cell differentiation to type 1 regulatory $\mathrm{T}(\mathrm{Tr} 1$ ) cells. Proc Natl Acad Sci U S A, 108, 18995-9000. 
LEE, J., PARK, M. K., LIM, M. A., PARK, E. M., KIM, E. K., YANG, E. J., LEE, S. Y., JHUN, J. Y., PARK, S. H., KIM, H. Y. \& CHO, M. L. 2013. Interferon gamma suppresses collagen-induced arthritis by regulation of Th17 through the induction of indoleamine-2,3-deoxygenase. PLoS One, 8, e60900.

LEE, S. E., LI, X., KIM, J. C., LEE, J., GONZALEZ-NAVAJAS, J. M., HONG, S. H., PARK, I. K., RHEE, J. H. \& RAZ, E. 2012. Type I interferons maintain Foxp3 expression and T-regulatory cell functions under inflammatory conditions in mice. Gastroenterology, 143, 145-54.

LI, M. O., WAN, Y. Y., SANJABI, S., ROBERTSON, A. K. \& FLAVELL, R. A. 2006. Transforming growth factor-beta regulation of immune responses. Annu Rev Immunol, 24, 99-146.

LIANG, B., WORKMAN, C., LEE, J., CHEW, C., DALE, B. M., COLONNA, L., FLORES, M., LI, N., SCHWEIGHOFFER, E., GREENBERG, S., TYBULEWICZ, V., VIGNALI, D. \& CLYNES, R. 2008. Regulatory T cells inhibit dendritic cells by lymphocyte activation gene-3 engagement of $\mathrm{MHC}$ class II. J Immunol, 180, 5916-26.

LIVAK, K. J. \& SCHMITTGEN, T. D. 2001. Analysis of relative gene expression data using real-time quantitative PCR and the 2(-Delta Delta C(T)) Method. Methods, 25, 402-8.

LOVGREN, T., ELORANTA, M. L., BAVE, U., ALM, G. V. \& RONNBLOM, L. 2004. Induction of interferonalpha production in plasmacytoid dendritic cells by immune complexes containing nucleic acid released by necrotic or late apoptotic cells and lupus IgG. Arthritis Rheum, 50, 1861-72.

MAGNUSSON, M., ZARE, F. \& TARKOWSKI, A. 2006. Requirement of type I interferon signaling for arthritis triggered by double-stranded RNA. Arthritis Rheum, 54, 148-57.

MANLAPAT, A. K., KAHLER, D. J., CHANDLER, P. R., MUNN, D. H. \& MELLOR, A. L. 2007. Cellautonomous control of interferon type I expression by indoleamine 2,3-dioxygenase in regulatory CD19+ dendritic cells. Eur J Immunol, 37, 1064-71.

MARTIN, E., CAPINI, C., DUGGAN, E., LUTZKY, V. P., STUMBLES, P., PETTIT, A. R., O'SULLIVAN, B. \& THOMAS, R. 2007. Antigen-specific suppression of established arthritis in mice by dendritic cells deficient in NF-kappaB. Arthritis Rheum, 56, 2255-66.

MAURI, C. \& CARTER, N. 2009. Is there a feudal hierarchy amongst regulatory immune cells? More than just Tregs. Arthritis Res Ther, 11, 237.

MCINNES, I. B. \& SCHETT, G. 2011. The pathogenesis of rheumatoid arthritis. N Engl J Med, 365, 2205-19.

MCNAB, F., MAYER-BARBER, K., SHER, A., WACK, A. \& O'GARRA, A. 2015. Type I interferons in infectious disease. Nat Rev Immunol, 15, 87-103.

MD YUSOF, M. Y. \& EMERY, P. 2013. Targeting interleukin-6 in rheumatoid arthritis. Drugs, 73, 34156.

MELLADO, M., MARTINEZ-MUNOZ, L., CASCIO, G., LUCAS, P., PABLOS, J. L. \& RODRIGUEZ-FRADE, J. M. 2015. T Cell Migration in Rheumatoid Arthritis. Front Immunol, 6, 384.

MELLOR, A. L., BABAN, B., CHANDLER, P. R., MANLAPAT, A., KAHLER, D. J. \& MUNN, D. H. 2005. Cutting edge: $\mathrm{CpG}$ oligonucleotides induce splenic CD19+ dendritic cells to acquire potent indoleamine 2,3-dioxygenase-dependent T cell regulatory functions via IFN Type 1 signaling. J Immunol, 175, 5601-5.

MELLOR, A. L. \& MUNN, D. H. 2004. IDO expression by dendritic cells: tolerance and tryptophan catabolism. Nat Rev Immunol, 4, 762-74.

MENSAH, K. A., MATHIAN, A., MA, L., XING, L., RITCHLIN, C. T. \& SCHWARZ, E. M. 2010. Mediation of nonerosive arthritis in a mouse model of lupus by interferon-alpha-stimulated monocyte differentiation that is nonpermissive of osteoclastogenesis. Arthritis Rheum, 62, 1127-37.

MEZRICH, J. D., FECHNER, J. H., ZHANG, X., JOHNSON, B. P., BURLINGHAM, W. J. \& BRADFIELD, C. A. 2010. An interaction between kynurenine and the aryl hydrocarbon receptor can generate regulatory T cells. J Immunol, 185, 3190-8.

MILLER, J. C., MA, Y., BIAN, J., SHEEHAN, K. C., ZACHARY, J. F., WEIS, J. H., SCHREIBER, R. D. \& WEIS, J. J. 2008. A critical role for type I IFN in arthritis development following Borrelia burgdorferi infection of mice. J Immunol, 181, 8492-503. 
MOELANTS, E. A., MORTIER, A., VAN DAMME, J. \& PROOST, P. 2013. Regulation of TNF-alpha with a focus on rheumatoid arthritis. Immunol Cell Biol, 91, 393-401.

MONACH, P. A., MATHIS, D. \& BENOIST, C. 2008. The K/BxN arthritis model. Curr Protoc Immunol, Chapter 15, Unit 1522.

MUNN, D. H. \& MELLOR, A. L. 2013. Indoleamine 2,3 dioxygenase and metabolic control of immune responses. Trends Immunol, 34, 137-43.

MUNN, D. H., SHARMA, M. D., BABAN, B., HARDING, H. P., ZHANG, Y., RON, D. \& MELLOR, A. L. 2005. GCN2 kinase in T cells mediates proliferative arrest and anergy induction in response to indoleamine 2,3-dioxygenase. Immunity, 22, 633-42.

NACU, N., LUZINA, I. G., HIGHSMITH, K., LOCKATELL, V., POCHETUHEN, K., COOPER, Z. A., GILLMEISTER, M. P., TODD, N. W. \& ATAMAS, S. P. 2008. Macrophages produce TGF-betainduced (beta-ig-h3) following ingestion of apoptotic cells and regulate MMP14 levels and collagen turnover in fibroblasts. J Immunol, 180, 5036-44.

NADIR, F., FAGIUOLI, S., WRIGHT, H. I., NADIR, A., HOPP, E., GAVALER, J. \& VAN THIEL, D. H. 1994. Rheumatoid arthritis: a complication of interferon therapy. J Okla State Med Assoc, 87, 22830.

NARENDRA, S. C., CHALISE, J. P., HOOK, N. \& MAGNUSSON, M. 2014. Dendritic cells activated by double-stranded RNA induce arthritis via autocrine type I IFN signaling. J Leukoc Biol, 95, 6616.

NESTLE, F. O., CONRAD, C., TUN-KYI, A., HOMEY, B., GOMBERT, M., BOYMAN, O., BURG, G., LIU, Y. J. \& GILLIET, M. 2005. Plasmacytoid predendritic cells initiate psoriasis through interferonalpha production. J Exp Med, 202, 135-43.

NGUYEN, N. T., KIMURA, A., NAKAHAMA, T., CHINEN, I., MASUDA, K., NOHARA, K., FUJII-KURIYAMA, Y. \& KISHIMOTO, T. 2010. Aryl hydrocarbon receptor negatively regulates dendritic cell immunogenicity via a kynurenine-dependent mechanism. Proc Natl Acad Sci U S A, 107, 19961-6.

NOTLEY, C. A., BROWN, M. A., WRIGHT, G. P. \& EHRENSTEIN, M. R. 2011. Natural IgM is required for suppression of inflammatory arthritis by apoptotic cells. J Immunol, 186, 4967-72.

OLOFSSON, P., NERSTEDT, A., HULTQVIST, M., NILSSON, E. C., ANDERSSON, S., BERGELIN, A. \& HOLMDAHL, R. 2007. Arthritis suppression by NADPH activation operates through an interferon-beta pathway. BMC Biol, 5, 19.

PAGUIRIGAN, A. M., BYRNE, G. I., BECHT, S. \& CARLIN, J. M. 1994. Cytokine-mediated indoleamine 2,3-dioxygenase induction in response to Chlamydia infection in human macrophage cultures. Infect Immun, 62, 1131-6.

PALLOTTA, M. T., ORABONA, C., BIANCHI, R., VACCA, C., FALLARINO, F., BELLADONNA, M. L., VOLPI, C., MONDANELLI, G., GARGARO, M., ALLEGRUCCI, M., TALESA, V. N., PUCCETTI, P. \& GROHMANN, U. 2014. Forced IDO1 expression in dendritic cells restores immunoregulatory signalling in autoimmune diabetes. J Cell Mol Med, 18, 2082-91.

PALLOTTA, M. T., ORABONA, C., VOLPI, C., VACCA, C., BELLADONNA, M. L., BIANCHI, R., SERVILLO, G., BRUNACCI, C., CALVITTI, M., BICCIATO, S., MAZZA, E. M., BOON, L., GRASSI, F., FIORETTI, M. C., FALLARINO, F., PUCCETTI, P. \& GROHMANN, U. 2011. Indoleamine 2,3-dioxygenase is a signaling protein in long-term tolerance by dendritic cells. Nat Immunol, 12, 870-8.

PARK, M. J., PARK, H. S., CHO, M. L., OH, H. J., CHO, Y. G., MIN, S. Y., CHUNG, B. H., LEE, J. W., KIM, H. Y. \& CHO, S. G. 2011. Transforming growth factor beta-transduced mesenchymal stem cells ameliorate experimental autoimmune arthritis through reciprocal regulation of Treg/Th17 cells and osteoclastogenesis. Arthritis Rheum, 63, 1668-80.

PARK, M. J., PARK, K. S., PARK, H. S., CHO, M. L., HWANG, S. Y., MIN, S. Y., PARK, M. K., PARK, S. H. \& KIM, H. Y. 2012. A distinct tolerogenic subset of splenic IDO(+)CD11b(+) dendritic cells from orally tolerized mice is responsible for induction of systemic immune tolerance and suppression of collagen-induced arthritis. Cell Immunol, 278, 45-54.

PARK, M. K., PARK, J. S., PARK, E. M., LIM, M. A., KIM, S. M., LEE, D. G., BAEK, S. Y., YANG, E. J., WOO, J. W., LEE, J., KWOK, S. K., KIM, H. Y., CHO, M. L. \& PARK, S. H. 2014. Halofuginone 
ameliorates autoimmune arthritis in mice by regulating the balance between Th17 and Treg cells and inhibiting osteoclastogenesis. Arthritis Rheumatol, 66, 1195-207.

PASSOS DE SOUZA, E., EVANGELISTA SEGUNDO, P. T., JOSE, F. F., LEMAIRE, D. \& SANTIAGO, M. 2001. Rheumatoid arthritis induced by alpha-interferon therapy. Clin Rheumatol, 20, 297-9.

PERFETTO, S. P., CHATTOPADHYAY, P. K. \& ROEDERER, M. 2004. Seventeen-colour flow cytometry: unravelling the immune system. Nat Rev Immunol, 4, 648-55.

PESTKA, S., KRAUSE, C. D. \& WALTER, M. R. 2004. Interferons, interferon-like cytokines, and their receptors. Immunol Rev, 202, 8-32.

PICONESE, S., PACELLA, I., TIMPERI, E. \& BARNABA, V. 2015. Divergent effects of type-I interferons on regulatory T cells. Cytokine Growth Factor Rev, 26, 133-41.

PLATANIAS, L. C. 2005. Mechanisms of type-I- and type-II-interferon-mediated signalling. Nat Rev Immunol, 5, 375-86.

POHLERS, D., SIEGLING, A., BUCHNER, E., SCHMIDT-WEBER, C. B., PALOMBO-KINNE, E., EMMRICH, F., BRAUER, R. \& KINNE, R. W. 2005. Expression of cytokine mRNA and protein in joints and lymphoid organs during the course of rat antigen-induced arthritis. Arthritis Res Ther, 7, R445-57.

PUCCETTI, P. 2007. On watching the watchers: IDO and type I/II IFN. Eur J Immunol, 37, 876-9.

QUAH, B. J. \& PARISH, C. R. 2010. The use of carboxyfluorescein diacetate succinimidyl ester (CFSE) to monitor lymphocyte proliferation. J Vis Exp.

RAZ, E., DUDLER, J., LOTZ, M., BAIRD, S. M., BERRY, C. C., EISENBERG, R. A. \& CARSON, D. A. 1995. Modulation of disease activity in murine systemic lupus erythematosus by cytokine gene delivery. Lupus, 4, 286-92.

ROELEVELD, D. M. \& KOENDERS, M. I. 2015. The role of the Th17 cytokines IL-17 and IL-22 in Rheumatoid Arthritis pathogenesis and developments in cytokine immunotherapy. Cytokine, 74, 101-7.

ROELOFS, M. F., WENINK, M. H., BRENTANO, F., ABDOLLAHI-ROODSAZ, S., OPPERS-WALGREEN, B., BARRERA, P., VAN RIEL, P. L., JOOSTEN, L. A., KYBURZ, D., VAN DEN BERG, W. B. \& RADSTAKE, T. R. 2009. Type I interferons might form the link between Toll-like receptor (TLR) $3 / 7$ and TLR4-mediated synovial inflammation in rheumatoid arthritis (RA). Ann Rheum Dis, 68, 148693.

RONNBLOM, L. \& PASCUAL, V. 2008. The innate immune system in SLE: type I interferons and dendritic cells. Lupus, 17, 394-399.

RUSSELL, M. W., SIBLEY, D. A., NIKOLOVA, E. B., TOMANA, M. \& MESTECKY, J. 1997. IgA antibody as a non-inflammatory regulator of immunity. Biochem Soc Trans, 25, 466-70.

RUTGER PERSSON, G. 2012. Rheumatoid arthritis and periodontitis - inflammatory and infectious connections. Review of the literature. J Oral Microbiol, 4.

SAAS, P. \& PERRUCHE, S. 2012. Functions of TGF-beta-exposed plasmacytoid dendritic cells. Crit Rev Immunol, 32, 529-53.

SAKAGUCHI, S., SAKAGUCHI, N., ASANO, M., ITOH, M. \& TODA, M. 1995. Immunologic self-tolerance maintained by activated T cells expressing IL-2 receptor alpha-chains (CD25). Breakdown of a single mechanism of self-tolerance causes various autoimmune diseases. J Immunol, 155, 1151-64.

SAKAGUCHI, S., YAMAGUCHI, T., NOMURA, T. \& ONO, M. 2008. Regulatory T cells and immune tolerance. Cell, 133, 775-87.

SCHER, J. U. \& ABRAMSON, S. B. 2011. The microbiome and rheumatoid arthritis. Nat Rev Rheumatol, 7, 569-78.

SCOTT, G. N., DUHADAWAY, J., PIGOTT, E., RIDGE, N., PRENDERGAST, G. C., MULLER, A. J. \& MANDIKNAYAK, L. 2009. The immunoregulatory enzyme IDO paradoxically drives B cell-mediated autoimmunity. J Immunol, 182, 7509-17.

SHARMA, M. D., BABAN, B., CHANDLER, P., HOU, D. Y., SINGH, N., YAGITA, H., AZUMA, M., BLAZAR, B. R., MELLOR, A. L. \& MUNN, D. H. 2007. Plasmacytoid dendritic cells from mouse tumor- 
draining lymph nodes directly activate mature Tregs via indoleamine 2,3-dioxygenase. J Clin Invest, 117, 2570-82.

SHIOZAWA, S., CHIHARA, K., SHIOZAWA, K., FUJITA, T., IKEGAMI, H., KOYAMA, S. \& KURIMOTO, M. 1986. A sensitive radioimmunoassay for alpha-interferon: circulating alpha-interferon-like substance in the plasma of healthy individuals and rheumatoid arthritis patients. Clin Exp Immunol, 66, 77-87.

SIGURDSSON, S., PADYUKOV, L., KURREEMAN, F. A., LILEDAHL, U., WIMAN, A. C., ALFREDSSON, L., TOES, R., RONNELID, J., KLARESKOG, L., HUIZINGA, T. W., ALM, G., SYVANEN, A. C. \& RONNBLOM, L. 2007. Association of a haplotype in the promoter region of the interferon regulatory factor 5 gene with rheumatoid arthritis. Arthritis Rheum, 56, 2202-10.

SIMON, J., SURBER, R., KLEINSTAUBER, G., PETROW, P. K., HENZGEN, S., KINNE, R. W. \& BRAUER, R. 2001. Systemic macrophage activation in locally-induced experimental arthritis. $J$ Autoimmun, 17, 127-36.

SLEIJFER, S., BANNINK, M., VAN GOOL, A. R., KRUIT, W. H. J. \& STOTER, G. 2005. Side effects of interferon-alpha therapy. Pharmacy World \& Science, 27, 423-431.

SMEETS, T. J., DAYER, J. M., KRAAN, M. C., VERSENDAAL, J., CHICHEPORTICHE, R., BREEDVELD, F. C. \& TAK, P. P. 2000. The effects of interferon-beta treatment of synovial inflammation and expression of metalloproteinases in patients with rheumatoid arthritis. Arthritis Rheum, 43, 270-4.

SONG, C., LUO, L., LEI, Z., LI, B., LIANG, Z., LIU, G., LI, D., ZHANG, G., HUANG, B. \& FENG, Z. H. 2008. IL17-producing alveolar macrophages mediate allergic lung inflammation related to asthma. $J$ Immunol, 181, 6117-24.

SRIVASTAVA, S., KOCH, M. A., PEPPER, M. \& CAMPBELL, D. J. 2014. Type I interferons directly inhibit regulatory $T$ cells to allow optimal antiviral T cell responses during acute LCMV infection. J Exp Med, 211, 961-74.

SUGIMOTO, H., ODA, S., OTSUKI, T., HINO, T., YOSHIDA, T. \& SHIRO, Y. 2006. Crystal structure of human indoleamine 2,3-dioxygenase: catalytic mechanism of $\mathrm{O} 2$ incorporation by a hemecontaining dioxygenase. Proc Natl Acad Sci U S A, 103, 2611-6.

SVARD, A., KASTBOM, A., SOMMARIN, Y. \& SKOGH, T. 2012. Salivary IgA antibodies to cyclic citrullinated peptides (CCP) in rheumatoid arthritis. Immunobiology.

SVENSSON, B. \& HAFSTROM, I. 2011. Effects on joint destruction and remission, bone turnover and lack of influence on atherogenesis: a review of the BARFOT low-dose prednisolone studies on patients with early RA. Clin Exp Rheumatol, 29, S63-7.

SZANTO, S., KORENY, T., MIKECZ, K., GLANT, T. T., SZEKANECZ, Z. \& VARGA, J. 2007a. Inhibition of indoleamine 2,3-dioxygenase-mediated tryptophan catabolism accelerates collagen-induced arthritis in mice. Arthritis Res Ther, 9, R50.

SZANTO, S., KORENY, T., MIKECZ, K., GLANT, T. T., SZEKANECZ, Z. \& VARGA, J. 2007b. Inhibition of indoleamine 2,3-dioxygenase-mediated tryptophan catabolism accelerates collagen-induced arthritis in mice. Arthritis Research \& Therapy, 9, R50.

TAILOR, P., TAMURA, T., KONG, H. J., KUBOTA, T., KUBOTA, M., BORGHI, P., GABRIELE, L. \& OZATO, K. 2007. The feedback phase of type I interferon induction in dendritic cells requires interferon regulatory factor 8 . Immunity, 27, 228-39.

TAK, P. P. \& BRESNIHAN, B. 2000. The pathogenesis and prevention of joint damage in rheumatoid arthritis: advances from synovial biopsy and tissue analysis. Arthritis Rheum, 43, 2619-33.

TAK, P. P., HART, B. A., KRAAN, M. C., JONKER, M., SMEETS, T. J. \& BREEDVELD, F. C. 1999. The effects of interferon beta treatment on arthritis. Rheumatology (Oxford), 38, 362-9.

TAKAYANAGI, H., KIM, S., MATSUO, K., SUZUKI, H., SUZUKI, T., SATO, K., YOKOCHI, T., ODA, H., NAKAMURA, K., IDA, N., WAGNER, E. F. \& TANIGUCHI, T. 2002. RANKL maintains bone homeostasis through c-Fos-dependent induction of interferon-beta. Nature, 416, 744-9.

TEIJARO, J. R., NG, C., LEE, A. M., SULLIVAN, B. M., SHEEHAN, K. C., WELCH, M., SCHREIBER, R. D., DE LA TORRE, J. C. \& OLDSTONE, M. B. 2013. Persistent LCMV infection is controlled by blockade of type I interferon signaling. Science, 340, 207-11. 
TERAWAKI, S., CHIKUMA, S., SHIBAYAMA, S., HAYASHI, T., YOSHIDA, T., OKAZAKI, T. \& HONJO, T. 2011. IFN-alpha directly promotes programmed cell death-1 transcription and limits the duration of T cell-mediated immunity. J Immunol, 186, 2772-9.

THEOFILOPOULOS, A. N., BACCALA, R., BEUTLER, B. \& KONO, D. H. 2005. Type I interferons (alpha/beta) in immunity and autoimmunity. Annu Rev Immunol, 23, 307-36.

THOMPSON, J. M., WHITMORE, A. C., STAATS, H. F. \& JOHNSTON, R. 2008. The contribution of type I interferon signaling to immunity induced by alphavirus replicon vaccines. Vaccine, 26, 49985003.

THORNTON, A. M. \& SHEVACH, E. M. 1998. CD4+CD25+ immunoregulatory T cells suppress polyclonal T cell activation in vitro by inhibiting interleukin 2 production. J Exp Med, 188, 287-96.

TRESCHOW, A. P., TEIGE, I., NANDAKUMAR, K. S., HOLMDAHL, R. \& ISSAZADEH-NAVIKAS, S. 2005. Stromal cells and osteoclasts are responsible for exacerbated collagen-induced arthritis in interferon-beta-deficient mice. Arthritis Rheum, 52, 3739-48.

TRIANTAPHYLLOPOULOS, K. A., WILLIAMS, R. O., TAILOR, H. \& CHERNAJOVSKY, Y. 1999. Amelioration of collagen-induced arthritis and suppression of interferon-gamma, interleukin-12, and tumor necrosis factor alpha production by interferon-beta gene therapy. Arthritis Rheum, 42 , 90-9.

TRINCHIERI, G. 2010. Type I interferon: friend or foe? J Exp Med, 207, 2053-63.

VAN DEN BERG, W. B., JOOSTEN, L. A. \& VAN LENT, P. L. 2007. Murine antigen-induced arthritis. Methods Mol Med, 136, 243-53.

VAN DER HEIJDEN, I. M., WILBRINK, B., TCHETVERIKOV, I., SCHRIJVER, I. A., SCHOULS, L. M., HAZENBERG, M. P., BREEDVELD, F. C. \& TAK, P. P. 2000. Presence of bacterial DNA and bacterial peptidoglycans in joints of patients with rheumatoid arthritis and other arthritides. Arthritis Rheum, 43, 593-8.

VAN HOLTEN, J., PAVELKA, K., VENCOVSKY, J., STAHL, H., ROZMAN, B., GENOVESE, M., KIVITZ, A. J., ALVARO, J., NUKI, G., FURST, D. E., HERRERO-BEAUMONT, G., MCINNES, I. B., MUSIKIC, P. \& TAK, P. P. 2005. A multicentre, randomised, double blind, placebo controlled phase II study of subcutaneous interferon beta-1a in the treatment of patients with active rheumatoid arthritis. Ann Rheum Dis, 64, 64-9.

VAN HOLTEN, J., PLATER-ZYBERK, C. \& TAK, P. P. 2002. Interferon-beta for treatment of rheumatoid arthritis? Arthritis Res, 4, 346-52.

VAN HOLTEN, J., REEDQUIST, K., SATTONET-ROCHE, P., SMEETS, T. J., PLATER-ZYBERK, C., VERVOORDELDONK, M. J. \& TAK, P. P. 2004. Treatment with recombinant interferon-beta reduces inflammation and slows cartilage destruction in the collagen-induced arthritis model of rheumatoid arthritis. Arthritis Res Ther, 6, R239-49.

WILLIAMS, R. O. 2013. Exploitation of the IDO Pathway in the Therapy of Rheumatoid Arthritis. Int J Tryptophan Res, 6, 67-73.

WILSON, E. B., YAMADA, D. H., ELSAESSER, H., HERSKOVITZ, J., DENG, J., CHENG, G., ARONOW, B. J., KARP, C. L. \& BROOKS, D. G. 2013. Blockade of chronic type I interferon signaling to control persistent LCMV infection. Science, 340, 202-7.

WING, K., ONISHI, Y., PRIETO-MARTIN, P., YAMAGUCHI, T., MIYARA, M., FEHERVARI, Z., NOMURA, T. \& SAKAGUCHI, S. 2008. CTLA-4 control over Foxp3+ regulatory T cell function. Science, 322, 271-5.

WING, K. \& SAKAGUCHI, S. 2010. Regulatory T cells exert checks and balances on self tolerance and autoimmunity. Nat Immunol, 11, 7-13.

WINTHROP, K. L. 2006. Serious infections with antirheumatic therapy: are biologicals worse? Ann Rheum Dis, 65 Suppl 3, iii54-7.

WONG, P. K., QUINN, J. M., SIMS, N. A., VAN NIEUWENHUIJZE, A., CAMPBELL, I. K. \& WICKS, I. P. 2006. Interleukin- 6 modulates production of T lymphocyte-derived cytokines in antigeninduced arthritis and drives inflammation-induced osteoclastogenesis. Arthritis Rheum, 54, 158-68. 
WONG, T., MAJCHRZAK, B., BOGOCH, E., KEYSTONE, E. C. \& FISH, E. N. 2003. Therapeutic implications for interferon-alpha in arthritis: a pilot study. J Rheumatol, 30, 934-40.

YAN, N. \& CHEN, Z. J. 2012. Intrinsic antiviral immunity. Nat Immunol, 13, 214-22.

YAN, Y., ZHANG, G. X., GRAN, B., FALLARINO, F., YU, S., LI, H., CULLIMORE, M. L., ROSTAMI, A. \& XU, H. 2010. IDO upregulates regulatory $T$ cells via tryptophan catabolite and suppresses encephalitogenic $\mathrm{T}$ cell responses in experimental autoimmune encephalomyelitis. J Immunol, 185, 5953-61.

YARILINA, A., DICARLO, E. \& IVASHKIV, L. B. 2007. Suppression of the effector phase of inflammatory arthritis by double-stranded RNA is mediated by type I IFNs. J Immunol, 178, 2204-11.

YARILINA, A., PARK-MIN, K. H., ANTONIV, T., HU, X. \& IVASHKIV, L. B. 2008. TNF activates an IRF1dependent autocrine loop leading to sustained expression of chemokines and STAT1dependent type I interferon-response genes. Nat Immunol, 9, 378-87.

ZARE, F., BOKAREWA, M., NENONEN, N., BERGSTROM, T., ALEXOPOULOU, L., FLAVELL, R. A. \& TARKOWSKI, A. 2004. Arthritogenic properties of double-stranded (viral) RNA. J Immunol, 172, 5656-63.

ZHOU, L., LOPES, J. E., CHONG, M. M., IVANOV, II, MIN, R., VICTORA, G. D., SHEN, Y., DU, J., RUBTSOV, Y. P., RUDENSKY, A. Y., ZIEGLER, S. F. \& LITTMAN, D. R. 2008. TGF-beta-induced Foxp3 inhibits $\mathrm{T}(\mathrm{H}) 17$ cell differentiation by antagonizing RORgammat function. Nature, 453, 236-40.

ZHU, L., JI, F., WANG, Y., ZHANG, Y., LIU, Q., ZHANG, J. Z., MATSUSHIMA, K. \& CAO, Q. 2006. Synovial autoreactive T cells in rheumatoid arthritis resist IDO-mediated inhibition. J Immunol, 177, 8226-33. 


\section{Papers}

The articles associated with this thesis have been removed for copyright reasons. For more details about these see:

http://urn.kb.se/resolve?urn=urn:nbn:se:liu:diva-122463 